Florida International University FIU Digital Commons

3-15-2002

\title{
The construct of work commitment: testing an integrative framework
}

\author{
Amy Rachelle Cooper \\ Florida International University
}

DOI: $10.25148 /$ etd.FI14061505

Follow this and additional works at: https://digitalcommons.fiu.edu/etd

Part of the Psychology Commons

\section{Recommended Citation}

Cooper, Amy Rachelle, "The construct of work commitment: testing an integrative framework" (2002). FIU Electronic Theses and Dissertations. 2523.

https://digitalcommons.fiu.edu/etd/2523

This work is brought to you for free and open access by the University Graduate School at FIU Digital Commons. It has been accepted for inclusion in FIU Electronic Theses and Dissertations by an authorized administrator of FIU Digital Commons. For more information, please contact dcc@fiu.edu. 
FLORIDA INTERNATIONAL UNIVERSITY

Miami, Florida

THE CONSTRUCT OF WORK COMMITMENT:

TESTING AN INTEGRATIVE FRAMEWORK

A dissertation submitted in partial fulfillment of the

requirements for the degree of

DOCTOR OF PHILOSOPHY

in

PSYCHOLOGY

by

Amy Rachelle Cooper

2002 
To: Dean Arthur W. Herriott

College of Arts and Sciences

This dissertation, written by Amy Rachelle Cooper, and entitled The Construct of Work Commitment: Testing an Integrative Framework, having been approved in respect to style and intellectual content, is referred to you for judgment.

We have read this dissertation and recommend that it be approved.

Juan I. Sanchez

Michelle Marks

Erik Larson

Chockalingam Viswesvaran, Major Professor

Date of Defense: March 15, 2002

The dissertation of Amy Rachelle Cooper is approved.

Dean Arthur W. Herriott College of Arts and Sciences

Dean Douglas Wartzok University Graduate School

Florida International University, 2002 


\section{DEDICATION}

I dedicate this dissertation to my family and friends. Thank you for all of your support and encouragement. I love you. Elad, as we embark on our new life together, thank you for your everlasting gifts of love, trust, and patience. To my dear family, thank you for always encouraging me to follow my dreams. To my many wonderful friends, I treasure you and hope that we will continue to share in life's blessings. 


\section{ACKNOWLEDGMENTS}

I wish to thank the members of my committee for their unyielding support and guidance. I would especially like to thank my major professor, Dr. Chockalingam Viswesvaran, for his patience, direction, and continuous instruction.

I would also like to thank the interlibrary loan staff for their help. I am grateful to Ana Arteaga for her diligent pursuit of much needed articles. 


\title{
ABSTRACT OF THE DISSERTATION
}

\section{THE CONSTRUCT OF WORK COMMITMENT:}

\section{TESTING AN INTEGRATIVE FRAMEWORK}

\author{
by
}

Amy Rachelle Cooper

Florida International University, 2002

Miami, Florida

Professor Chockalingam Viswesvaran, Major Professor

This dissertation meta-analytically examined the expansive material associated with work commitment. Work commitment, a multidimensional construct, encompasses the level of involvement an employee has with his or her work, organization, job, career, and union (Morrow \& Goetz, 1998). Each of the dimensions of work commitment has been further divided into a number of subdimensions. The primary purpose of this study was to (1) cumulate the correlations found among each of the dimensions of work commitment to see which, if any, were intercorrelated, and to (2) determine the impact of work commitment dimensions and subdimensions on specific outcome variables (job satisfaction, job performance, and turnover).

A number of interesting results stemmed from the 213 separate meta-analyses that were conducted. First, the evidence did not indicate that all of the subdimensions for each respective dimension were positively correlated. Specifically, there was not enough evidence to indicate that continuance organizational commitment was positively correlated 
with its other organizational commitment subdimensions. Future research might consider revamping the work commitment taxonomy so that all subdimensions that fall within a particular dimension are interrelated. It might be appropriate, therefore, to drop continuance organizational commitment from the work commitment taxonomy. Second, while most of the respective dimensions were interrelated, this was not the case across the board. For instance, there was no evidence of a significant positive relationship between organizational commitment and union commitment. In fact, the only significant relationship was negative between organizational commitment and belief in unionism.

Further, there was no evidence of a positive relationship between union commitment and either work ethic endorsement or job involvement, respectively. These findings supported Morrow's (1993) rationale for excluding union commitment from the work commitment taxonomy. 


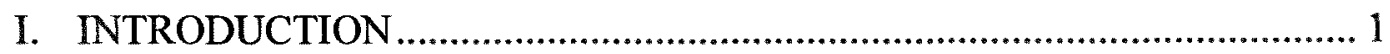

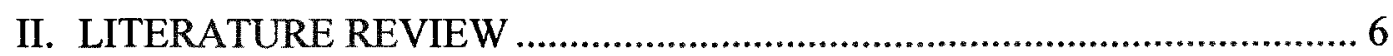

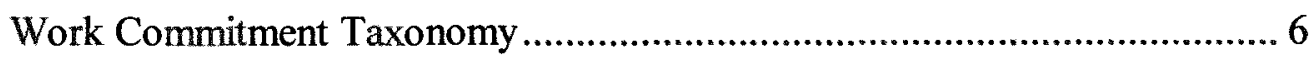

Dimensions of Work Commitment ......................................................... 7

A. Organizational Commitment ….................................................. 7

B. Job Involvement..................................................14

C. Career/Professional/Occupational Commitment................... 17

D. Work Ethic Endorsement........................................23

E. Union Commitment............................................. 27

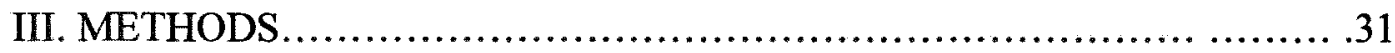

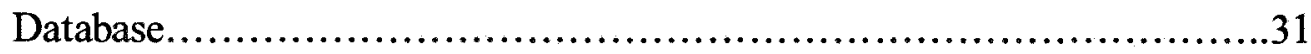

Procedure............................................................. 32

Analyses.............................................................. 33

Coding Decisions............................................... 36

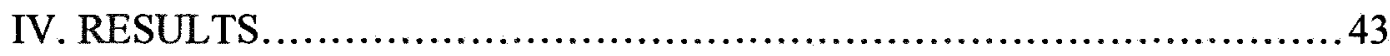

Dropped Variables.................................................... 43

Frequency Distribution of Available Studies.............................. 44

Reliability of the Assessments....................................... 45

Intercorrelations Among Subdimensions.......................... 47

Testing the Hypotheses.............................................. 49 
V. DISCUSSION

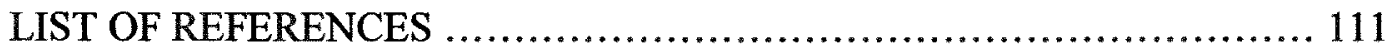

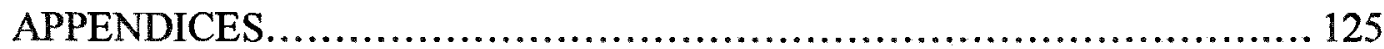

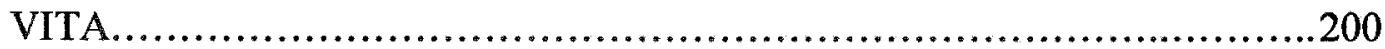




\section{LIST OF TABLES}

TABLE

PAGE

1. Work Commitment Terms Adapted from Morrow's $(1983,1993)$

Taxomony..... 86

2. Additional Work Commitment Terms from the Literature 87

3. Proposed Taxonomy of Work Commitment Terms 88

4. Levels of Moderators Used in the Study 89

5. Top Measures of Organizational Commitment 90

6. Top Measures of Job Involvement 91

7. Top Measures of Career/Professional/Occupational Commitment 92

8. Top Measures of Work Ethic Endorsement 93

9. Top Measures of Union Commitment 94

10. Top Measures of Outcome Variables. 95

11. Reliabilities Table 96

12. Meta-Analytic Results, Organizational Commitment Variables 97

13. Meta-Analytic Results, Job Involvement and CPO Variables. 98

14. Meta-Analytic Results, Work Ethic Endorsement Variables 99

15. Meta-Analytic Results, Union Commitment Variables 100

16. Meta-Analytic Results of Work and Organizational Commitment Variables with Outcomes. 101

17. Meta-Analytic Results of Job Involvement and CPO Variables with Outcomes 102 
18. Meta-Analytic Results of Work Ethic Endorsement Variables and Outcomes 103

19. Meta-Analytic Results: Union Commitment Variables and Outcomes ..104

20. Meta-Analytic Results: Organizational Commitment with Job Involvement, CPO 105

21. Meta-Analytic Results: Organizational Commitment with Work Ethic Endorsement Variables 106

22. Meta-Analytic Results: Organizational Commitment and Union Commitment Variables 107

23. Meta-Analytic Results: Job Involvement, CPO, and Work Ethic Endorsement 108

24. Meta-Analytic Results: Job Involvement, CPO, and Union Commitment Variables 109

25. Meta-Analytic Results: Work Ethic Endorsement and Union Commitment Variables 110 


\section{CHAPTER I}

\section{Introduction}

Work commitment is a central topic in organizational behavior (Mowday, Porter, $\&$ Steers, 1982). This concept encompasses the level of involvement an employee has with his or her work, organization, job, career, and union (Morrow \& Goetz, 1988). Work commitment is a multidimensional construct (Morrow, 1983, 1993). In fact, much research has looked at various dimensions of work commitment and how those dimensions differentially impact organizational outcomes (cf. Mathieu \& Zajac, 1990; Morrow, 1983, 1993). Work commitment is negatively correlated with variables like employee turnover, absenteeism, and job theft (Morrow, 1993; Mowday et al., 1982; Steers \& Rhodes, 1978; Tett $\&$ Meyer, 1993). Work commitment is positively correlated with outcome variables like job satisfaction and job performance (Mowday et al., 1982; Tett \& Meyer, 1993).

The umbrella term of work commitment has been divided into a number of subdimensions, some of which are broader than others and are themselves further subdivided. Each of these dimensions and subdimensions collectively falls under the broader work commitment term while maintaining certain individual nuances. While a number of work commitment dimensions have been derived, there has not been much work done either to determine the specific impact of each concept or to assess the interrelationships among the various dimensions and subdimensions (cf. Morrow, 1983).

It is important to discern whether different sources of commitment are related, and also, how each of the dimensions and subdimensions is differentially related to various organizational outcomes. Hence, this dissertation cumulated the expansive material 
associated with the various dimensions of work commitment. A meta-analysis was conducted on (1) the correlations found among each of the dimensions of work commitment and also on (2) the correlations between each of the respective dimensions and important outcome variables.

While some meta-analyses have looked at specific work commitment facets like job involvement or organizational commitment (e.g., Brown, 1996; Mathieu \& Zajac, 1990), all of the articles written on the various dimensions of work commitment had not been meta-analyzed in one study. This is an extremely important task, in that it advances our study of organizational behavior, as it pinpoints which dimensions are interrelated as well as which dimensions might be more likely to affect specific outcome variables (Morrow, 1983).

There are certain outcome variables which are of particular interest to organizations and employers. These include job satisfaction, job performance, and employee turnover (cf. Mathieu \& Zajac, 1990; Riggio, 1999; Tett \& Meyer, 1993). I specifically chose to explore these outcome variables because a preponderance of the literature considers work commitment and its relationship with these variables. I investigated the various dimensions of work commitment in order to gain a better understanding of the intercorrelations among the dimensions as well as the respective impact of each dimension on job satisfaction, job performance, and turnover.

Job satisfaction is referred to as a person's "affective attachment" to his or her occupation (Tett \& Meyer, 1993). It has even been dubbed "morale" by some researchers (Kim, Price, Mueller, \& Watson, 1996). Job satisfaction is vital because it affects 
employees' attitudes toward work and the organization. It has been linked to a decrease in turnover and absenteeism (Beehr, 1996; Hackett, 1989).

Interestingly, job satisfaction is only minimally related to job performance (e.g., correlation of .17; Iaffaldano \& Muchinsky, 1985). However, it is correlated with increased motivation, job involvement, organizational citizenship behavior, and organizational commitment (Kreitner \& Kinicki, 1998).

Job performance is cited as an outcome variable that can be greatly impacted by certain human resource management practices (Becker \& Gerhart, 1996). Job performance is important because an increase in output increases organizational effectiveness and may heighten net earnings of an organization (Becker \& Gerhart, 1996). There is disagreement in the literature as to the definition of job performance. Campbell, McCloy, Oppler and Sager (1993) specifically emphasize the behavioral aspect of performance. They state that performance is that behavior which is under the control of the employee. Others (e.g., Bernardin \& Beatty, 1984) measure performance by the outcomes that the organization gains (loses) due to employee behavior. Regardless, performance is of critical importance to an organization because it impacts the company's bottom line (cf. Becker \& Gerhart, 1996).

Turnover is an organizational outcome variable which deals with employees leaving an organization (Tett \& Meyer, 1993). It is seen as an organizational withdrawal variable, as things like organizational commitment, attachment to an employing organization, and certain behavioral objectives have been cited as precursors of turnover (Hanisch \& Hulin, 1991; Mobley, Griffeth, Hand, \& Meglino, 1979). 
Mobley et al. (1979) indicate that turnover is negatively correlated with job satisfaction, age, tenure, and desire to stay at an organization. Interestingly, Trevor, Gerhart, and Boudreau (1997) found a curvilinear relationship with turnover and performance. Specifically, turnover was greater for poor and excellent performers than it was for normal performers.

For theoretical as well as for practical purposes, it is important to understand the process by which the various facets of work commitment influence these important organizational outcome variables. The objective of this paper was to gain an understanding of the substantive role of work commitment as a global concept, and also as it pertains to each of the respective work commitment dimensions and subdimensions. The goal was to better understand how both the global concept and its respective dimensions impact job satisfaction, turnover, and job performance. By cumulating the correlations across these variables (the dimensions of work commitment, job satisfaction, job performance, and turnover) reported in the literature, meta-analytically derived correlations were used to further investigate the relationships between these important variables.

The use of meta-analytically derived correlations to test path models has several advantages (Viswesvaran \& Ones, 1995). First, the increased sample size greatly mitigates the effects of sampling error and facilitates detection of moderator effects (Aiken $\&$ West, 1993). Further, the use of heterogeneous samples increases the generalizability of the results (Ganster, Fusilier, \& Mayes, 1986). Additionally, meta-analytic research 
appears to be most appropriate here, since it would be extremely difficult and impractical to administer so many measures to the same sample.

In summary, the objective of this dissertation was two-fold: (a) to cumulate the extant literature reporting correlations between the various dimensions of work commitment to see which, if any, of the dimensions are intercorrelated and (b) to determine the impact of work commitment (as a whole) along with the impact of the various dimensions of work commitment on specific outcome variables (job satisfaction, job performance, and turnover). This examination of interrelationships between dimensions and the impact of each dimension on three outcome variables (job satisfaction, job performance, and turnover) parallels what Nunnally and Bernstein (1994, p. 104-105) refer to as the internal and cross-structure analysis of a construct. A work commitment taxonomy as well as specific hypotheses are delineated in Chapter Two. 


\section{CHAPTER II}

\section{Literature Review}

In this chapter, I first outline the work commitment taxonomy that has been generated for the purpose of this dissertation. The remainder of this chapter examines the meaning and respective roles of each of the dimensions of work commitment. There are five sections, one for each of the main dimensions of work commitment. The order in which each of the dimensions and subdimensions are presented follows the taxonomy presented below. Specific hypotheses are formulated within each section.

\section{Work Commitment Taxonomy}

The following taxonomy was devised by focusing on the major terms describing facets of work commitment in the literature. In her research on work commitment, Morrow $(1983,1993)$ presents a well-organized framework of various work commitment terms. This taxonomy is delineated in Table 1. Additionally, searches were conducted on PsychInfo and on the Social Science Citation Index to locate any other applicable terms. This investigation included a search of: (1) all meta-analyses conducted with commitment as one of the variables and (2) any term which appeared in the literature but not in Morrow's $(1983,1993)$ work. Dimensions were kept for use in the taxonomy only if there were at least ten articles that had used the specific term. A list of the additional terms is found in Table 2. The completed taxonomy used in this dissertation is found in Table 3. 


\section{Dimensions of Work Commitment}

Following is a detailed exploration of each of the dimensions and subdimensions delineated in the work commitment taxonomy. As mentioned above, there are five sections, one for each of the main categories of work commitment (e.g., organizational commitment, work ethic endorsement). Within each section, the definitions of the respective dimension and subdimensions are stated. Additionally, each section investigates the following four issues: (1) the intercorrelation among subdimensions, (2) the relationship of respective dimensions and subdimensions with outcome variables, (3) moderator effects, and (4) the intercorrelation between respective dimensions with other dimensions within the taxonomy. The moderator effects of dimension-dimension correlations are not explored. Specific hypotheses follow discussion of each of these particular issues. An examination of additional potential moderators is found in Appendix A.

\section{A. Organizational Commitment}

Organizational commitment has been defined as " the strength of an individual's identification with and involvement in a particular organization" (Porter, Steers, Mowday, \& Boulian, 1974, p.604). One who is high in organizational commitment wants to: (1) stay with his or her organization, (2) work for the good of the organization, and (3) adhere to the prominent values of the organization (Mowday, Steers, \& Porter, 1979; Porter et al., 1974). 


\section{Intercorrelation among Subdimensions}

Researchers have identified a number of different subdimensions that describe specific aspects of organizational commitment (e.g. Meyer \& Allen, 1984; Porter et al., 1974). Attitudinal organizational commitment, which occurs among employees most frequently, is the degree of involvement that a person has with his or her employing organization (Porter et al., 1974). Calculative organizational commitment, defined by Hrebiniak and Alutto (1972), occurs when a person is committed to an organization because leaving the organization would result in the employee not receiving needed money or "side bets" that he or she would get by remaining with the company (i.e., retirement plan; cf. Becker, 1960). People with high attitudinal organizational commitment stay with a company because they desire to do so, while employees with a lot of calculative commitment stay with a company because they have to in order to get money and related benefits (cf. Meyer, Allen, \& Gellatly, 1990). Interestingly, a person might start out with calculative organizational commitment when beginning work with an organization, but, over time, he or she might become attitudinally committed to the organization. Or, alternately, a person might join an organization because of attitudinal commitment, but continue to stay because of accumulated side bets resulting in calculative organizational commitment. Therefore, these subdimensions are, indeed, intertwined (Mathieu \& Zajac, 1990).

The above two subdimensions are similar to the subdimensions proposed by Meyer and Allen (1984), namely affective organizational commitment, and continuance organizational commitment. Similar in meaning to attitudinal commitment, affective 
organizational commitment deals with how closely a person relates to and is interested in being a part of his or her organization (Meyer \& Allen, 1984). Meyer and Allen (1984) devised this construct to be used in place of or in addition to a measure of attitudinal commitment when measuring organizational commitment (cf. Morrow, 1993). It is important to note that, while the terms affective commitment and attitudinal commitment are similar, they are explored separately in this dissertation in an attempt to follow the framework provided by Morrow (1993). Further, by analyzing them separately, it is possible to test their extent of actual overlap. Therefore, in this dissertation, I kept affective and attitudinal commitment separate. Continuance commitment is quite similar to calculative commitment, although the term also considers how easy it would be to leave one organization for another job (Meyer \& Allen, 1984). This term was devised to use in place of a measure of calculative commitment (cf. Morrow, 1993). As with attitudinal and affective commitment, both calculative and continuance commitment were analyzed separately here. Finally, normative organizational commitment occurs when a person becomes committed to an organization because the employee feels that this is how he or she ought to behave (Allen \& Meyer, 1990).

Interestingly, Mathieu and Zajac (1990) indicate that, while related, attitudinal commitment and calculative commitment are, indeed, individual constructs. In a similar vein, Meyer et al. (1990) conducted a confirmatory factor analysis which showed that, while related, affective commitment and continuance commitment are, also, individual constructs. However, the general trend in the literature suggests that these subdimensions are positively correlated. 
Hypothesis 1: The subdimensions (i.e., attitudinal organizational commitment, calculative organizational commitment, affective organizational commitment, continuance organizational commitment, and normative organizational commitment) of organizational commitment will be positively correlated.

\section{Relationship with Outcome Variables}

In a meta-analysis on organizational commitment, Mathieu and Zajac (1990) indicate that organizational commitment is positively correlated with motivation and job satisfaction, while it is negatively correlated with stress. This reflects the notion that a committed worker is a happy worker.

Organizational commitment has been linked to increases in performance and organizational output (Cohen, 1992; Mathieu \& Zajac, 1990). Randall (1990) found that organizational commitment is positively associated with increased effort and timeliness when arriving to work, while it is negatively correlated with turnover. Interestingly, while job performance is not strongly correlated with organizational commitment, job performance is negatively correlated with turnover (Mathieu \& Zajac, 1990).

Mathieu and Zajac (1990) found that one's level of organizational commitment negatively impacts absenteeism and turnover within an organization. In fact, organizational commitment is seen as a better predictor of turnover than is job satisfaction (cf. Cohen, 1992; Williams \& Hazer, 1986). And, Eby, Freeman, Rush, and Lance (1999) indicate that affective commitment is negatively correlated with absenteeism and turnover. 
Hypothesis 2: Organizational commitment and its subdimensions will be positively correlated with job satisfaction and job performance and negatively correlated with turnover.

\section{Moderator Effects}

I discuss three moderators in this section. Due to the fact that there is one main dimension and five subdimensions of organizational commitment and because there are three outcome variables of interest, there exists the potential for 18 relationships that could have been affected by moderators. However, I have found support for moderating effects for only three such relationships.

The first moderator to be discussed is the type of organization (e.g., public versus private) to which an employee belongs. In their meta-analysis on reward and organizational commitment, Cohen and Gattiker (1994) found that the correlation between organizational commitment and satisfaction is higher in private than in public organizations. With 31 samples and a total sample size of 10,455 , Cohen and Gattiker (1994) explain that in private organizations, rewards have a stronger impact on an employee's organizational commitment than they do in public organizations. This is because "organizations differ in the primary mechanisms used to control the work behavior of their members" (Cohen \& Gattiker, 1994, p. 139). Private organizations are more interested in profit, rewarding short-term behavior and performance, while public organizations reward for things like seniority (Brown, 1996). This argument is expanded from the facet level (e.g., pay satisfaction) to the global level (e.g., job satisfaction in general) here. 
Hypothesis 3: Type of organization (e.g., public versus private) will serve as a moderator in the organizational commitment-job satisfaction relationship, such that the relationship will be stronger for those in a private organization.

The next moderator to be discussed is career stage of the employee. Career stage, as indicated by the age and tenure of an employee, serves as a moderator of the relationship between organizational commitment and job performance (Cohen, 1991). In a meta-analysis of 41 samples, late-career stage, as indicated by older age and more tenure, had the strongest relationship between organizational commitment and performance (Cohen, 1991). Cohen (1991) states that those in early or mid-level career stages have less experience than those in later career stages. "Organizational commitment will have a limited effect on performance in the early stage because these employees' main obstacle is their lack of experience" (Cohen, 1991, p.257).

Career stage has also served as a moderator of the organizational commitmentturnover relationship. In fact, Cohen (1991) indicates that it is especially beneficial to improve work commitment when one is at the beginning of his or her career, as this will greatly reduce turnover of the employee. Career stage is important here because younger employees are more apt to leave an organization if there are problems within the organization or if a better opportunity surfaces elsewhere. Older and more tenured employees, on the other hand, have more time and energy invested in the organization, and are, in turn, more committed and less likely to leave the organization (cf. Cohen, 1991). In another meta-analysis with over 10,000 subjects, Cohen (1993b) found that 
people who are younger as well as people who have greater tenure are more committed to an organization in general. In yet another meta-analysis with more than 36,000 subjects, Cohen (1993a) found that the relationship between organizational commitment and turnover is stronger for younger people than for older people, for the reasons mentioned above.

Hypothesis 4a: Age will serve as a moderator in the: (a) organizational commitment-job performance relationship, such that the relationship will be stronger for older employees; (b) organizational commitment-turnover relationship, such that the relationship will be stronger for younger employees.

Hypothesis $4 b$ : Tenure will serve as a moderator in the: (a) organizational commitment-job performance relationship, such that the relationship will be stronger for more tenured employees; (b) organizational commitmentturnover relationship, such that the relationship will be stronger for those with less tenure.

The final moderator that will be discussed is that of type of job. In yet another meta-analytic study with 36 samples and over 10,000 subjects, Cohen and Hudecek (1993) found that the relationship between organizational commitment and turnover was weaker for blue-collar employees than for white-collar employees. Due to extensive schooling and training, white-collar workers generally have skills that can be easily transferred to a variety of work settings. Therefore, white-collar workers are more apt to leave an organization for other employment opportunities. Blue-collar workers, on the 
other hand, lack extensive education and generally gain their job-related skills through onthe-job training. This results in fewer opportunities for blue-collar workers to transfer to other organizations (Cohen \& Hudecek, 1993).

Hypothesis 5: Type of job (e.g., blue-collar versus white-collar) will serve as a moderator in the organizational commitment-turnover relationship, such that the relationship will be stronger for those with white-collar jobs.

\section{Intercorrelation between Dimensions within the Taxonomy}

Organizational commitment, as it relates to other dimensions (e.g., job involvement), is discussed in future sections of this dissertation.

\section{B. Job Involvement}

Lodahl and Kejner (1965) instituted the term job involvement. Job involvement is defined as the amount that an employee psychologically relates to his or her job and to the work performed therein. It is often "a function of how much the job can satisfy one's present needs" (Kanungo, 1982, p. 342). Job involvement is also indicated by the way that job performance impacts an employee's self esteem (Lodahl \& Kejner, 1965).

One who has high job involvement will be personally impacted by the ongoings at work (cf. Cook, Hepworth, Wall, \& Warr, 1981). And, people who are promoted from within a company often have more job involvement than someone who is chosen externally (cf. Dailey \& Morgan, 1978). Some researchers (cf. Farrell \& Rusbult, 1981; Morrow, 1993) have referred to these aspects of work commitment as job commitment. So, in this dissertation, any studies that use the term job commitment are treated as job involvement. 


\section{Intercorrelation among Subdimensions}

There are no identified subdimensions of job involvement, since job involvement is a monolithic dimension.

\section{Relationship with Outcome Variables}

One's level of job involvement affects his or her level of job satisfaction, as job involvement is significantly and positively correlated with job satisfaction (Brown, 1996; Kahn, 1990; Schuler, 1977). In fact, one who is extremely involved in his or her job is happier, according to the literature, than one who is not involved in his or her work (Lodahl \& Kejner, 1965). However, in a recent meta-analysis on this dimension, job involvement was not significantly related to performance, absenteeism, or turnover (Brown, 1996).

Hypothesis 6: Job involvement will be positively correlated with job satisfaction and will not be significantly correlated with either job performance or turnover.

\section{Moderator Effects}

I discuss one moderator in this section. Due to the fact that there is one main dimension of job involvement and because there are three outcome variables of interest, there exists the potential for three relationships that could have been affected by moderators. I have found support for moderating effects in all three such relationships.

Interestingly, Brown (1996) found evidence for type of organization (e.g., public versus private) to serve as a moderator in the relationship between job involvement and outcome variables. Specifically, there is a stronger relationship between job involvement 
and outcome variables in private organizations than in public organizations. This might be due to the fact that private organizations are more interested in profit and, therefore, reward appropriate short-term behavior and performance. In public organizations, on the other hand, rewards are more likely to be related to seniority within an organization. (Brown, 1996). Therefore, the psychological relationship between the employee and organization is stronger in private than in public organizations (Brown, 1996).

Hypothesis 7: Type of organization (e.g., public versus private) will serve as a moderator in the: (a) job involvement-job satisfaction relationship, such that the relationship will be stronger for employees in private organizations; (b) job involvement-job performance relationship, such that the relationship will be stronger for employees in private organizations; (c) job involvement-turnover relationship, such that the relationship will be stronger for employees in public organizations.

\section{Intercorrelation between Dimensions within the Taxonomy}

Interestingly, there was a definite strong correlation between organizational commitment and job involvement, although they are separate constructs (Brown, 1996; Mathieu \& Zajac, 1990). Brown (1996) specifically indicates that correlations with organizational commitment and turnover are stronger than correlations between job involvement and turnover. There is also a positive correlation between job commitment and organizational commitment (Morrow, 1993). Further, there is not a significantly different correlation between global job satisfaction and either job involvement or organizational commitment. 
Hypothesis 8: Job involvement will be positively correlated with organizational commitment.

\section{Career/ProfessionalOccupational Commitment}

The term Career/Professional/Occupational commitment (CPO) encompasses one's commitment or dedication to his or her career, profession, or occupation (cf. Blau, 1985; Morrow \& Goetz, 1988). The subdimensions of career commitment, professional commitment, and occupational commitment have been placed in one major category specifically because one's career, profession, and occupation are often viewed as synonyms (cf. Lee, Carswell, \& Allen, 2000). However, it is important to note the distinction between these constructs. Professional commitment is the degree to which employees are involved in their profession while career commitment is referring to the employee's dedication to his or her career, per se (Aranya, Pollack, \& Amernic, 1981; Blau, 1985; Morrow \& Goetz, 1988; Morrow \& Wirth, 1989). And, occupational commitment refers to one's level of involvement with his or her occupation (Lee et al, 2000). One's career may span more than one occupation.

Specifically, professional commitment refers to a person's desire to: (1) agree with and adhere to the prominent values of the profession, (2) work for the good of the profession, and (3) continue working in the profession (Aranya et al., 1981). Career commitment, on the other hand, is described by the advancement of individual vocational goals, and by the drive and commitment associated with completing these goals (Colarelli \& Bishop, 1990). Career commitment is important because it enables an employee to develop the needed skills and relationships in order to have a profitable career, regardless 
of the organization within which he or she is employed (Colarelli \& Bishop, 1990).

Meanwhile, occupational commitment is defined as "a psychological link between a person and his or her occupation that is based on affective reaction to that occupation" (Lee et al., 2000, p.800).

\section{Intercorrelation among Subdimensions}

A number of subdimensions fall within this broad category of CPO. The first of these subdimensions to be discussed is career salience. Career salience is defined as the significance that an employee places on his or her career (Greenhaus, 1971). Interestingly, in addition to being used as a synonym for career commitment, professional commitment has also been dubbed career salience (Wallace, 1993). Career involvement is defined as the degree of identification with one's career (Gould, 1979). It is also considered the attitude with which one views his or her career (Gould, 1979).

The next subdimension to be discussed is professionalism. Professionalism is "the extent to which one identifies with one's profession and accepts its values" (Morrow \& Goetz, 1988, p.93). One who exhibits a high degree of professionalism is more likely to put new topics or courses of action into practice (Damanpour, 1991). Hall (1968) noted five indicators of professionalism: (1) the utilization of the profession and of peers within the profession when making decisions, (2) confidence that the profession contributes meaningfully to the community, (3) faith that the profession should be controlled by people within the profession, (4) confidence that fellow members of the profession believe that this profession is their mission in life, and (5) an assumption that those within the profession are allowed to conduct various endeavors without needing others' consent. 
The last three subdimensions to be discussed in this subsection are affective occupational commitment, continuance occupational commitment, and normative occupational commitment. Interestingly, Meyer, Allen, \& Smith (1993) branched-out their organizational commitment model to one of occupational commitment. So, these subdimensions are very similar in meaning to their organizational commitment subdimension counterparts. Specifically, affective occupational commitment is when a person stays with his or her occupation because he or she desires to do so (cf. Irving, Coleman, \& Cooper, 1997; Meyer \& Allen, 1984). With continuance occupational commitment, a person is committed to his or her occupation because it would be difficult to leave the occupation for another occupation, and because leaving the occupation would result in the person not receiving needed money and the like (cf. Irving et. al, 1997; Meyer \& Allen, 1984). With normative occupational commitment, a person stays with his or her occupation because he or she feels that he or she ought to do so (cf. Allen \& Meyer, 1990; Irving et al., 1997). Interestingly, confirmatory factor analysis indicated that affective, continuance, and normative occupational commitment are, respectively, considered distinct subdimensions in various occupations (Irving et al., 1997). The general trend in the literature does indicate that these subdimensions are positively correlated.

Hypothesis 9: The subdimensions (i.e., career salience, career involvement, professionalism, affective occupational commitment, continuance occupational commitment, and normative occupational commitment) of CPO will be positively correlated. 
Morrow $(1983,1993)$ has listed local/cosmopolitanism (L/C) under the professional commitment dimension. $\mathrm{L} / \mathrm{C}$ is a term used by Gouldner (1958) to differentiate between people who are either committed to their profession (cosmopolitans) or to their organization (locals). While the "cosmopolitanism" term does, indeed, relate to professional commitment, the "local" aspect refers to committed people in an organization. Therefore, while L/C is placed here in an effort to follow Morrow's (1993) framework, it is considered a "free-floater" among the organizational commitment and CPO dimensions.

\section{Relationship with Outcome Variables}

Occupational commitment is positively correlated with job satisfaction (Irving et al, 1997; Lee et al., 2000). Career salience is also correlated with job satisfaction (Greenhaus, 1971).

Career salience is correlated with performance outcome variables like self-rated effort and accomplishments (Greenhaus, 1971). Occupational commitment is also positively correlated with job performance. Due to the sometimes synonymous application of the terms occupational commitment, professional commitment, and career commitment, it can be inferred that these findings are applicable to the CPO dimension at large (cf. Lee et al., 2000).

Hypothesis 10: CPO and its subdimensions will be positively correlated with job satisfaction and job performance. 


\section{Moderator Effects}

I discuss two moderators in this section. Due to the fact that there is one main dimension and six subdimensions of CPO and because there are three outcome variables of interest, there exists the potential for 21 relationships that could have been affected by moderators. However, I have found support for moderators in only two such relationships.

The first moderator that will be discussed is locus of control. Locus of control serves as a moderator of the relationship between $\mathrm{CPO}$ and outcome variables. Those with an internal locus of control will be more likely to be committed to and involved in their careers (Colarelli \& Bishop, 1990; Gould, 1979). With their sample of 436 subjects, Colarelli and Bishop (1990) indicate that those with an internal locus of control have more effective careers than those with an external locus of control. This is seen as internals earn more money and have greater career advancement than do externals (Andrisani \& Nestel, 1976).

Hypothesis 11: Locus of control (e.g., internal versus external) will serve as a moderator in the: (a) CPO-job satisfaction relationship, such that the relationship will be stronger for employees with an internal locus of control; and (b) CPO-job performance relationship, such that the relationship will be stronger for employees with an internal locus of control.

The final moderator to be discussed here is age of employee. Age serves as a moderator of the relationships between CPO and outcome variables. Specifically, older 
people are more dedicated to their careers than are younger people (Colarelli \& Bishop, 1990). Colarelli and Bishop (1990) indicate that one's career commitment is enhanced as an employee becomes more focused on his or her career path. This occurs, specifically, as people age (Colarelli \& Bishop, 1990). Also, as a person gets older and stays with a particular career, he or she does not have as much time to learn new skills so as to make a career change. All of these reasons show how age can serve as a moderator between CPO and various outcome variables (Colarelli \& Bishop, 1990).

Hypothesis 12: Age will serve as a moderator of the: (a) CPO-job satisfaction relationship, such that the relationship will be stronger for older employees; and (b) CPO-job performance relationship, such that the relationship will be stronger for older employees.

\section{Intercorrelation between Dimensions within the Taxonomy}

Interestingly, $\mathrm{CPO}$ and organizational commitment have been found to be positively correlated (cf. Brierley, 1998). In fact, Wallace (1993) conducted a metaanalysis to see if professional commitment and organizational commitment are positively related. Her results indicate that the two variables, are, indeed, positively correlated. This is an important finding because it implies that one who is committed to his or her profession is not necessarily uncommitted to his or her organization. Interestingly, these findings are in conflict with the literature, which states that the two variables are necessarily negative in their correlation (e.g., March \& Simon, 1958). Wallace (1993) does point out, though, that one might be more dedicated to his or her profession than to his or her organization, even though the two are positively correlated. Morrow and Wirth 
(1989) indicate that professional commitment may be more important than organizational commitment when it comes to small companies and to those who are self-employed. CPO has also been found to be positively correlated with job involvement (Brown, 1996).

Concerning additional relationships between subdimensions mentioned in this section and other dimensions found in the taxonomy, Meyer, Allen, \& Smith (1993) actually branched-out their organizational commitment model when designing one of occupational commitment. While related, the two dimensions are completely different constructs (Irving et al., 1997). It has also been discerned in the literature that career salience is correlated with job involvement and organizational commitment (Greenhaus, 1971; Morrow, 1993).

Hypothesis 13: CPO will be positively correlated with organizational commitment and with job involvement.

\section{Work Ethic Endorsement}

Work ethic endorsement is the degree to which an employee "believes in the importance of work itself" (Morrow, 1993, p.1). This broad term encompasses the following more narrow subdimensions: Protestant work ethic endorsement, work ethic, work involvement, and employment commitment.

\section{Intercorrelation among Subdimensions}

Protestant work ethic endorsement, the first of the many subdimensions in this category, was initiated by Mirels and Garrett in 1971. Its use in psychology is an extension of the work on Protestant work ethic by Weber (1905). It deals with one's belief in diligent pursuit of work and monetary gain while ignoring one's own self-regard 
and while staying away from distractions (Furnham, 1990; Morrow, 1993). Interestingly, Mirels and Garrett (1971) indicate that jobs which ascribe to strict rules and regimented behavior (e.g., army officer, police officer) are more strongly correlated with Protestant work ethic endorsement than are jobs that are especially artistic or creative (e.g., artist, music teacher).

Work ethic deals with one's view that dedication to work itself is positive and necessary to succeed in society (Buchholz, 1976). This term is positively correlated with Protestant work ethic endorsement (Furnham, 1990). In fact, the definition of work ethic mirrors much of the definition of Protestant work ethic endorsement (cf. Buchholz, 1976; Dickson \& Buchholz, 1979). Buchholz (1976) defines work ethic as follows:

Work is good in itself and bestows dignity on a person. Everyone should work and those who don't are not useful members of society. By working hard a person can overcome every obstacle that life presents and make his own way in the world. Success is thus directly linked to one's own efforts and the material wealth a person accumulates is a measure of how much effort he has expended. Wealth should be wisely invested to earn still greater returns and not foolishly spent on personal consumption. Thus thrift and frugality are virtues to be practiced in the use of one's material possessions (p.1179).

Work involvement is defined as the degree that one relates to work itself (Kanungo, 1982). It is an idea that one has about the importance of work in his or her life (Kanungo, 1982). Finally, employment commitment is defined as the extent to which one desires to be employed (Jackson, Stafford, Banks, \& Warr, 1983). It is also determined by how dedicated one is to the labor market (Jackson et al., 1983). Interestingly, employment commitment serves as a moderator between status of employment and psychological anguish. Specifically, people with higher employment commitment "showed greater 
change in distress scores as a result of change in employment status" (Jackson et al., 1983, p.532).

Hypothesis 14: The subdimensions (i.e., Protestant work ethic endorsement, work ethic, work involvement, and employment commitment) of work ethic endorsement will be positively correlated.

\section{Relationship with Outcome Variables}

There is evidence of a slight correlation between Protestant work ethic endorsement and outcome variables like job satisfaction and job performance (Morrow \& McElroy, 1987). There is also evidence of a correlation between Protestant work ethic and intention to stay at a particular organization (Morrow \& McElroy, 1987). Since the subdimensions are hypothesized to be intercorrelated, it can be inferred that these findings are applicable to the work ethic endorsement dimension at large (cf. Morrow, 1993).

Hypothesis 15: Work ethic endorsement will be positively correlated with job satisfaction and job performance and negatively correlated with turnover.

\section{Moderator Effects}

I discuss one moderator in this section. Due to the fact that there is one main dimension and four subdimensions of work ethic endorsement and because there are three outcome variables of interest, there exists the potential for 15 relationships that could have been affected by moderators. However, I found support for moderating effects for only three such relationships. 
The only moderator that will be discussed in this section is age of the employee. The literature indicates that age may serve as a moderator between work ethic endorsement and outcome variables (cf. Morrow, 1983; Morrow \& McElroy, 1987). In fact, older people are more prone to work ethic endorsement in general (Morrow, 1983; Morrow \& McElroy, 1987). In their study with a sample of 2,200 employees, Morrow and McElroy (1987) found that older people are generally less likely to voluntarily leave an organization and are more satisfied with work. This might be because older people have fewer opportunities to change career paths and because they are more involved in their specific vocation.

Hypothesis 16: Age will serve as a moderator in the: (a) work ethic endorsement-job satisfaction relationship, such that the relationship will be stronger for older people; (b) work ethic endorsement-job performance relationship, such that the relationship will be stronger for older people; and (c) work ethic endorsement-turnover relationship, such that the relationship will be stronger for younger people.

IV. Intercorrelations between Dimensions within the Taxonomy

Work ethic endorsement is positively correlated with job involvement and organizational commitment (Brown, 1996; Morrow \& McElroy, 1986). At the subdimension level, Protestant work ethic endorsement and employment commitment are slightly correlated with job involvement and with organizational commitment (Jackson et al., 1983; Morrow \& McElroy, 1987). And, since CPO and organizational commitment 
have been found to be positively correlated in the literature (cf. Brierley, 1998), it can be inferred that work ethic endorsement is also correlated with CPO.

Hypothesis 17: Work ethic endorsement will be positively correlated with organizational commitment, job involvement, and CPO.

\section{E. Union Commitment}

In her 1983 article on work commitment, Morrow included union commitment in her framework as one of the many dimensions of work commitment. However, due to lack of continued research in this area, she did not include union commitment in the latest framework provided (Morrow, 1993). Regardless, union commitment, which refers to how dedicated one is to his or her union, is included in this dissertation to ensure the most complete coverage of the work commitment construct (cf. Gordon, Philpot, Burt, Thompson, \& Spiller, 1980).

People are generally more committed to their union when the union is fighting for worker rights and the like. In fact, union commitment is often based on the type and amount of benefits that the union can bestow on its members (Gordon et al, 1980). Also, union commitment can change quite frequently, depending on how often a person joins a new organization, profession, or job (cf. Morrow, 1983). Commitment is needed to guarantee the basic functioning of a union (Gordon et al., 1980).

\section{Intercorrelation among Subdimensions}

There are four main subdimensions of union commitment, namely union loyalty, responsibility to the union, willingness to work for the union, and belief in unionism (Gordon et al., 1980, p. 487). Union loyalty refers to the degree of allegiance that one 
has toward his or her union (Gordon et al., 1980). Responsibility to the union represents the desire that one has to complete daily requirements and responsibilities in order to maintain the union (Gordon et al., 1980). Willingness to work for the union refers to the desire one has to utilize his or her spare time to benefit the union (Gordon et al., 1980). Finally, belief in unionism refers to "the member's belief in the concept of unionism" (Gordon et al., 1980, p.487). The literature indicates that these subdimensions are positively correlated.

Hypothesis 18: The subdimensions (i.e., union loyalty, responsibility to the union, willingness to work for the union, and belief in unionism) of union commitment will be positively correlated.

\section{Relationship with Outcome Variables}

Interestingly, union commitment is negatively correlated with job satisfaction in the literature (Gordon et al., 1980). "Members who were dissatisfied with 'bread and butter' matters or with management were more willing to fulfill their normal obligations to the union as well as to perform special duties on behalf of the local" (Gordon et al., 1980; $\mathrm{p}$ 492). It can be inferred that union commitment is not significantly related to performance on the job (cf. Gordon et al, 1980; Morrow, 1983).

Hypothesis 19: Union commitment and its subdimensions will be negatively correlated with job satisfaction and will not be significantly related to job performance. 


\section{Moderator Effects}

I will be discussing one moderator in this section. Due to the fact that there is one main dimension and four subdimensions of union commitment and because there are three outcome variables of interest, there exists the potential for 15 relationships that could have been affected by moderators. I found support for moderating effects for two such relationships.

The moderator that will be discussed in this section is type of job. Johnson, Johnson, and Patterson (1999) indicate that type of job (e.g., white-collar versus bluecollar) might serve as a moderating variable when considering the relationship between union commitment and other variables. For instance, when comparing the relationship between company and union commitment, there was a stronger relationship for blue-collar employees than for white-collar employees (Johnson et al., 1999). This might be because white-collar employees have more employment opportunities than do blue-collar employees (cf. Cohen \& Hudecek, 1993). Those who believe that there are not too many job opportunities might maintain a stronger relationship with the union in hopes that the union will protect their position in their current place of employment.

Hypothesis 20: Type of job (e.g., white-collar versus blue-collar) will serve as a moderator in the: (a) union commitment-job satisfaction relationship, such that the relationship is stronger for blue-collar employees; and (b) union commitment-job performance relationship, such that the relationship will be stronger for blue-collar employees. 
Union commitment is only applicable to those who are union members (Morrow, 1983). This facet, therefore, is not as generalizable as some of the other work commitment facets (e.g., work ethic involvement, job involvement). Regardless, union commitment is still correlated with the other dimensions of work commitment (cf. Morrow, 1983, 1993). Specifically, union commitment is correlated with organizational commitment, job involvement, CPO, and work ethic endorsement (Mathieu \& Zajac, 1990; Morrow, 1983) An interesting difference between union commitment and organizational commitment is how voluntary the participation is within a union versus within an organization (Morrow, 1983). When someone joins an organization, it is almost always according to his or her own volition. But, sometimes a person has to join a union because he works for a particular organization (Morrow, 1983).

Hypothesis 21: Union commitment will be positively correlated with organizational commitment, job involvement, $\mathrm{CPO}$, and work ethic endorsement. 


\section{CHAPTER III}

\section{Methods}

\section{Database}

A computerized search was conducted on PsychInfo and on the Social Science Citation Index to identify articles to be used for the meta-analyses. Approximately 8,000 articles were found containing any of the following 26 key words: work commitment, organizational commitment, calculative organizational commitment, attitudinal organizational commitment, continuance organizational commitment, affective organizational commitment, normative organizational commitment, job involvement, job commitment, career commitment, professional commitment, occupational commitment, career salience, career involvement, professionalism, affective occupational commitment, calculative occupational commitment, normative occupational commitment, local/cosmopolitanism, work ethic endorsement, Protestant work ethic endorsement, work ethic, work involvement, employment commitment, union commitment, and unionism. Additionally, I "snowballed" the references from any applicable article or book (e.g., Brown, 1996; Mathieu \& Zajac, 1990; Morrow, 1993) to identify other potential articles. I did not actively seek conference articles or chapters from books. However, I included any that were identified in my search.

A total of 868 articles were tagged as appropriate for the meta-analysis. A complete list of citations of all articles used in the meta-analysis is provided in Appendix B. 
There were certain inclusion criteria used when designating articles: (1) The study needed to use employees in an actual organization; (2) There had to be evidence of at least either: (a) two of the 26 keywords (e.g., organizational commitment, job involvement) used in the study or (b) one of the 26 keywords and one of the aforementioned outcome variables (job satisfaction, job performance, or turnover) used in the study.

\section{Procedure}

After gathering all of the designated articles (see above for criteria), I coded the located articles. The correlations, their corresponding sample sizes, and the reliabilities of the measures were (abstracted and) coded. Also coded were the types of measures of the respective variables used in each study. It is important to note that the outcome variables (job satisfaction, job performance, and turnover) were coded globally. This means that facets of job satisfaction, for example, were not coded; however, job satisfaction, in general, was coded. Job satisfaction and job performance were coded such that a high number indicated a positive value (e.g., higher job satisfaction, greater job performance). Turnover was coded such that a high number indicated a larger amount of turnover. Reverse coding took place when needed for all applicable variables.

When age was used as a moderator, I used the average age in each sample and took a median split. Similarly, when tenure was used as a moderator, I used the average tenure in each sample and took the median split. When either type of organization (e.g., public versus private) or type of job (e.g., blue-collar versus white-collar) was used as a moderator, I disregarded any heterogeneous samples and coded accordingly. When locus 
of control was used as a moderator, one of two options occurred. For those samples using solely internal or external locus of control, I coded the study appropriately. However, if such a distinction was not made, I took the average of the locus of control measure and noted where it fell, according to Rotter and Mulray's (1965) scale for locus of control. The respective levels that were used when coding each moderator variable can be seen in Table 4.

\section{Analyses}

When testing zero-order correlations for bivariate relationship hypotheses concerning the relationship of dimensions and subdimensions with outcome variables (i.e., Hypotheses 2, 6, 10,15, and 19), one has an option of using $\rho$ (roe; true score correlation) or R-BAR. Since I focused only at the construct level, I used $\rho$. When considering effect size, one has an option: (1) to focus on correlational measures (e.g., $\rho$, where the respective value of the true score correlation represents either a small, medium, or large effect; Cohen, 1988), or (2) to utilize a $95 \%$ confidence interval for significance testing. I used the confidence interval approach here. For instance, when testing one of the direct effects models for Hypothesis 2, the true score correlation between, e.g., organizational commitment and job satisfaction was examined. A substantive positive correlation between organizational commitment and job satisfaction, where the $95 \%$ credibility interval excluded zero, was taken as evidence supporting that part of the hypothesis. To completely test Hypothesis 2, it is important to recognize that there were 18 distinct correlations of interest. This was due to the fact that the hypothesis considered organizational commitment and its five subdimensions as they respectively related to the 
three outcome variables. So, the same process mentioned above that was used to analyze the bivariate relationship between organizational commitment and job satisfaction was used to analyze each of the other 17 relationships highlighted in this hypothesis.

When analyzing hypotheses dealing with intercorrelations among subdimensions (i.e., Hypotheses $1,9,14$, and 18), one must choose again between using $\rho$ or R-BAR. I used the true score correlation because I was interested in the construct level. One might choose to look at the average true score correlation $(\rho)$ when testing these hypotheses. However, average standard deviation of $\rho$ is difficult to interpret. There are similar problems when using the sample size weighted standard deviation of $\rho$. So, factor analysis was utilized instead of the above possibilities. For instance, concerning Hypothesis 1, there are five subdimensions of organizational commitment. So, I conducted factor analysis with a 5-by-5 matrix. I assessed how much variance each factor explained as well as the root mean square residual. When conducting factor analysis, it is necessary to input the size of the sample being analyzed. There are a number of possibilities that one may use when determining the number to input for the sample size, namely: (1) the average sample size of all of the included studies, (2) the smallest sample size of all of the included studies, (3) the maximum sample size of all included studies, or (4) the harmonic mean. I chose to input the harmonic mean for the sample size in the factor analysis program. Finally, the hypotheses that I developed are stand-alone hypotheses. However, after testing the hypothesized models, I also tested for alternate models.

When testing for moderators that are discrete variables, like type of organization (i.e., Hypotheses 3 and 7) and type of job (i.e., Hypotheses 5 and 20), I dropped any 
heterogeneous samples and applied subgroup analysis. For instance, with Hypothesis 3, I discarded any heterogeneous samples that included both private and public employees (collectively). I also discarded any ambiguous samples. I was left with studies that assessed private and public organizations with separate sample groups. From there, I conducted subgroup analysis to test for a moderator effect. When using the $95 \%$ confidence intervals, if there was overlap, then there was no evidence of a moderator effect. If there was no overlap, then there was evidence of a moderator effect. It is important to note that when testing moderator hypotheses, any study including the related dimension or subdimensions was used, since the subdimensions are considered to be manifestations of the respective larger dimension. So, for instance, with Hypothesis 3, any study that discussed type of organization and either organizational commitment or any of its subdimensions was used when testing for moderator effects. Hence, organizational commitment or any of its subdimensions were treated as if they measured the same construct.

When testing for moderators that are continuous variables, like age or tenure (i.e., Hypotheses 4, 12, and 16), I first took the median split. For instance, with Hypothesis 4, I used the average sample age when coding the studies. The median split for age occurred at 35.7 years. So, when the average sample age was 35.6 years or less, it was coded as "younger" while a sample age of 35.7 years or higher was coded as "older." The median split for tenure occurred at 7.24 years. So, when the average sample tenure was 7.23 years or less, it was coded as "less tenured" while a sample tenure of 7.24 years or more was coded as "more tenured." (It is important to note here that if I would have taken into 
account the variability of age or tenure, the results might have changed.) Another moderator that is a continuous variable is locus of control (i.e., Hypothesis 11). In this case, if the study was specifically about those with either an internal or external locus of control, I coded accordingly. However, if the study reported only average values, one could either: (1) apply the median split, or (2) go to Rotter and Mulray's (1965) manual, see where the average value falls, and code accordingly (i.e., at the internal or external level). I used Rotter and Mulray's (1965) manual. Again, it is important to note that any study including the appropriate dimensions or subdimensions and the moderator variable of interest was used here.

When addressing hypotheses concerning intercorrelations between dimensions within the taxonomy (i.e., Hypotheses 8, 13, 17, and 21), any study including the respective dimensions or subdimensions was used, as the subdimensions are considered manifestations of the larger dimension in this dissertation. For instance, in Hypothesis 8, job involvement is a monolithic dimension, while organizational commitment has five subdimensions. Hence, there were six potential bivariate relationships to consider here. As mentioned above, $\rho$ was used because I was interested in the construct level relationship. And, confidence intervals were used when testing for significance.

\section{Coding Decisions}

There were a number of decisions that were made when coding to determine whether or not a particular article should be tagged as appropriate for inclusion in the meta-analysis. This section explicates the various determinations made when coding. 
There are six subheadings in this section, one for general coding decisions and one for each of the respective dimensions of work commitment.

\section{General Coding Decisions}

\section{a. Related to Subjects}

Studies were included only if they used actual employees in an organization. I did not use student samples, where subjects enacted a simulation (i.e., Allen \& Russell, 1999; Zellars \& Kacmar, 1999). Similarly, articles where nurses read scenarios and voted on a hypothetical employee's level of performance were not included (i.e., Grover, 1993).

A student's academic job involvement, academic commitment, and academic performance were not included as usable terms in this study. This was because it was determined that the studies used should only deal with one's level of commitment to his or her work organization, involvement with his or her job, and so forth. To clarify, a fulltime student's commitment to his or her university was not coded. However, a professor's commitment to his or her university was coded, since this was his or her place of employment. Similarly, teacher trainees' career commitment and job satisfaction were also deemed appropriate to code (e.g., Lam, Foong, \& Moo, 1995).

An article with a "convenience" sample (i.e., Furnham, 1997) was included, where $85 \%$ of the subjects labeled themselves as workers and $15 \%$ labeled themselves as students (but not necessarily as non-workers). This article was included in the dataset because it was possible for the remaining $15 \%$ of the subjects to have a job. And, since $85 \%$ of the subjects definitely worked for an organization, it seemed fitting to keep the article. 
A study with volunteer workers (i.e., Grube \& Piliavin, 2000) was included in the dataset. This article reported the commitment of volunteers to the organization for which they worked, and their intent to leave the organization. This study was permitted because the volunteers had a job; they just opted not to be paid for it. I also used an article that asked retired people to reflect on their job satisfaction and job involvement when they used to be employed (i.e., Schmitt, White, Coyle, \& Rauschenberger, 1979).

\section{b. Related to Outcome Variables}

Although pride in work is not generally the same as job satisfaction, it was coded as such with the Putti, Aryee, and Liang (1989) article. This was because the term was specifically defined as the feeling of satisfaction that an employee derived from work. Quality of work life was coded as job satisfaction in the Higgins, Duxbury, and Irving (1992) article. (According to the article, job satisfaction is a part of the broader term, quality of work life.) Outcome satisfaction was coded as job satisfaction in the Kim and Mauborgne (1993) study, based on the definition provided.

The term work enjoyment (i.e., my job is more like fun than work) was not counted as job satisfaction. Organizational morale was also not included as job satisfaction, since it was at the organizational level. And, satisfaction with training was not coded as job satisfaction. The specific article under consideration here (i.e. Mathieu, 1988) dealt with Army and Navy ROTC cadets' satisfaction with ROTC training and commitment to the ROTC in general. 
I coded over satisfaction as a measure of performance of a bank teller sample in the Shore and Martin (1989) article. Over satisfaction reflected positive performance in this article.

\section{c. Related to Moderator Variables}

When coding for age or tenure, I coded this variable as ambiguous unless the article clearly indicated the mean or median age or tenure. For instance, if the article said that $53 \%$ of the sample was 34 years of age, then I coded age as 34 . If, however, the article said that nearly half of the sample was 25 , then I coded that as ambiguous. If an age range was given, I took the median number.

When coding for type of organization, the organization in each study was coded as private, public, mixed, or unknown/ambiguous. Regarding type of job, the subjects were coded as either blue-collar, white-collar, mixed-collar, or unknown/ambiguous collar.

\section{d. Related to Correlations, LISREL}

Only articles that reported correlations were used in the meta-analysis. Therefore, if there were beta weights but no correlations reported, then the article was not used in this study. I coded all cross-lagged correlations. I did not include articles with ranges of correlations. When there was an option to code for a scale or a factor, I always coded the scale (e.g., Drasgow \& Miller, 1982).

I chose to include LISREL and interitem correlations in the dataset. I used any LISREL article that reported a correlation matrix, regardless of whether it reported corrected or uncorrected correlations. I dropped all articles that reported charts or path coefficients in a path model, since they offered no data for cumulation. With interitem 
correlations, I formed a composite of all scale items (cf. Nunnally \& Bernstein, 1994) and then took the appropriate correlations.

\section{e. Related to Problem Articles}

There were two Ting $(1996,1997)$ articles that appeared to use the same dataset, namely the Survey of Federal Employees. There was even similar wording in the articles. I decided to use only one article in the dataset. I chose to include the study with the larger sample size (Ting, 1996) and kept the other one for reference (Ting, 1997).

There was a problem with the matrix of an article written by Ko, Price, and Mueller (1997). It appeared as if every row needed to be shifted over in order to read the matrix properly. However, even with that adjustment, there were still some correlations that were unaccounted for. I sent an email to Price (co-author) on 10-24-01, requesting a copy of the matrix as it should read. He was unable to locate the matrix. Therefore, this article was not used in the meta-analysis.

\section{f. Related to Extraneous Commitment Terms}

There were a number of articles which mentioned names for commitment terms not included in the taxonomy, namely behavioral commitment, moral commitment, value commitment, compliance, internalization, identification, and instrumental commitment. I initially attempted to dub the terms as facets with similar meanings found within the taxonomy (e.g., behavioral commitment might be coded as continuance commitment). However, these additional terms did not conform to the construct domain found within the dissertation. Therefore, those articles which cited commitment terms other than those that easily (and cleanly) fit into the construct domain were not included in the analysis. Those 
terms which could fit easily into the construct domain were included in the analysis in the most general sense (e.g., as organizational commitment and not as one of the various facets of organizational commitment).

\section{g. Related to Publication Date of Articles}

This dissertation covered all articles through December 2000. However, some 2001 articles were detected during the data gathering process. It was determined that these 21 additional articles should be included in the meta-analysis for sake of thoroughness.

\section{Organizational Commitment Coding Decisions}

Organizational identification and organizational loyalty were coded as organizational commitment.

\section{Job Involvement Coding Decisions}

In the Indiresan (1975) article, job saliency was determined to be like job involvement. Therefore, the correlation between job saliency and job satisfaction was coded as if it were the correlation between job involvement and job satisfaction. Job dedication was coded as job involvement in the Van Scotter and Motowidlo (1996) article, since its definition included working diligently, taking initiative, and the like.

I chose not to use a study where job involvement was measured by the amount of hours that an employee worked. It was also determined not to include a study where constructs were measured at the group or organizational level. Job involvement was not coded in the study by Hall and Lawler (1970), since the job involvement scores for 
individuals were averaged for all respondents in the organization and performance was measured at the organizational level.

IV. Career/Professional/Occupational Commitment (CPO) Coding Decisions

Commitedness to the field of practice was coded as CPO in the Ben-Sira (1986) article, since it described how much one wanted to remain in his or her specific field of medicine.

\section{Work Ethic Endorsement Coding Decisions}

Military ethos was coded as work ethic, since it was described as a measure of professional military values (i.e., Guimond, 1995). Work role centrality and central llfe interest were coded as either job involvement or work ethic endorsement, depending on the definition provided in the article (e.g., Elfering, Semmer, \& Kalin, 2000). When an article dealt with a facet of, i.e., Protestant work ethic endorsement, I coded each facet as Protestant work ethic endorsement, since I did not specifically explore the facets of subdimensions in this meta-analysis.

\section{Union Commitment Coding Decisions}

The term union instrumentality was generally not considered to be the same as union commitment. However, it was coded as general union commitment in the Fullager (1986) article, when it was specifically described as a union commitment variable. In the Shore, Tetrick, Sinclair, and Newton (1994) article, the term general attitude toward unions was considered to be similar enough to belief in unionism to be coded as such. 


\section{CHAPTER IV}

\section{Results}

This chapter is divided into five sections. The first section discusses dropped variables. The second section delineates the frequency distribution of available studies. The third section assesses the reliability analysis. The fourth section reviews the intercorrelations among the 18 subdimensions. Finally, the fifth section tests the 21 respective hypotheses.

\section{A. Dropped Variables}

Of the 8,000 articles that were reviewed, there were not enough tagged articles that reported locus of control. Specifically, there were 20 studies that used locus of control as it pertained to the hypotheses (e.g., in an article about career commitment). However, only 12 of those studies reported a mean value. Further, of these 12, five cited Rotter (1966) for their scale, one cited Valecha (1972), four cited Spector (1988), and two cited Levenson (1973). When using locus of control as a moderator variable, there were two options that were available for analyses: (1) If the study was specifically about those with an internal or external locus of control, I could code accordingly; (2) If the study reported only average values, I could go to Rotter and Mulray's (1965) manual, see where the average value fell, and code accordingly (i.e., at the internal or external level). However, neither option could be utilized here due to the distribution of articles. Therefore, this moderator was unable to be tested. So, Hypothesis 11 was not included in the analysis. Similarly, only five articles in the dataset mentioned self-esteem. Therefore, all analyses with self-esteem were also dropped. 
There were only four articles tagged as appropriate for the meta-analysis that used local/cosmopolitanism as a construct of interest. Therefore, this term was dropped from the analysis. Two of the articles (i.e., Baack, Luthans, \& Rogers 1993; McKelvey \& Sekaran, 1977) that included correlations with local/cosmopolitanism contained other usable correlations and were not dropped completely from the study. However, the two other articles were used only for reference, since they only contained local/cosmopolitanism constructs (i.e., Larwood, Wright, Desrochers, \& Dahir, 1998; London, Cheney, \& Tavis, 1977). Similarly, the one article that used the term employment commitment was better coded as work commitment (Wanberg et al., 1999). Hence, any analyses with employment commitment were dropped. So, portions of Hypotheses $14,15,16$, and 17 concerning employment commitment were not tested.

\section{B. Frequency Distribution of Available Studies}

The majority of the studies used in the meta-analysis addressed organizational commitment or one of its subdimensions. Job satisfaction was the most popular outcome variable used in the dataset. While this meta-analysis covered all studies until December 2000 , most of the tagged studies were from the last decade.

The measures of organizational commitment that were included in the database along with the frequencies of their use are listed in Table 5. Similarly, the scales or instruments used to measure job involvement, $\mathrm{CPO}$, work ethic endorsement, and union commitment are summarized in Tables $6,7,8$, and 9 , respectively. The scales used to measure the outcome variables in this study are found in Table 10. (In general, measures are included in the respective tables only if they are listed five or more times in the dataset 
for a particular subdimension. However, in instances where the measure with the greatest frequency for a subdimension is found fewer than five times in the dataset, this measure is still included in the table.)

\section{Reliability of the Assessments}

Table 11 summarizes the artifact distributions of the variables used. The table includes the mean and standard deviation of both frequency-weighted and sample sizeweighted reliabilities as well as those for the square root of reliabilities for each of the constructs used in the meta-analyses.

The frequency-weighted mean is a simple average taken by adding up all of the reliability estimates and dividing by the total number of estimates. With the sample sizeweighted mean, however, the reliability estimate for each study is weighted based on the sample size for that particular study. The sum of each reliability estimate times its sample size is calculated before dividing by the total sample size (of all of the studies used). The benefit of using a frequency-weighted mean and standard deviation is that one study with a large sample size will not skew the results, since each reliability estimate is weighted the same. However, the sample size-weighted mean and standard deviation provide a more accurate figure (Viswesvaran, Ones, \& Schmidt, 1996). Hence, both are depicted in this dissertation. Reliabilities are included because we are interested in the internal consistency of the measures used (cf. Nunnally \& Bernstein, 1994). The square root of reliability is also included, though, as that is what is needed to conduct the meta-analysis. Generally, the reliabilities and square roots of reliability are similar, numerically. However, all of the terms defined above are included in Table 11 for sake of thoroughness. 
The mean frequency-weighted reliability ranged from .70 (for Protestant work ethic endorsement or PWE) to .88 (for union loyalty). The standard deviation of the frequency-weighted reliability varied from .0071 (for turnover) to .1272 (for PWE). The mean sample size-weighted reliability ranged from .67 (for PWE) to .87 (for union commitment and union loyalty). The variability of the sample size-weighted reliability ranged from .0048 (for turnover) to .1272 (for PWE).

The mean frequency-weighted square root of reliability varied from .83 (for PWE) to .94 (for union loyalty). The standard deviation of the frequency-weighted square root of reliability ranged from .0038 (for turnover) to .0841 (for PWE). The mean sample sizeweighted square root of reliability ranged from .81 (for PWE) to .93 (for union commitment and union loyalty). The variability of the sample size-weighted square root of reliability ranged from .0026 (for turnover) to .0838 (for PWE).

It is important to note the similarities of results across the frequency-weighted and sample size-weighted reliabilities and square roots of reliability. The PWE construct is the least reliable across the board. Union loyalty and union commitment are the most reliable overall. Turnover has the least amount of variability while PWE has the greatest variability, regardless of type of reliability or square root of reliability being assessed.

The mean frequency-weighted square root of reliability is the artifact distribution used in meta-analysis. This is why it is italicized in the table. All mean frequency-weighted square roots of reliability have values of acceptable magnitude (Nunnally and Bernstein, 1994). 


\section{Intercorrelations Among Subdimensions}

There are four tables that are described, in detail, in this section. Table 12 looks at the meta-analytic results for the organizational commitment subdimensions. Table 13 portrays the results for the job involvement and CPO terms. Tables 14 and 15 provide the work ethic endorsement and union commitment meta-analytic results, respectively.

Regarding the organizational commitment subdimensions, the number of estimates used in each meta-analysis ranged from one to 97 . The total sample size used in each meta-analysis varied from 133 to 27,569 . The sample size-weighted mean observed correlations (RBAR) varied from .01 to .51 . With organizational commitment, the true score correlation $(\rho)$ ranged from .02 to .63 . The highest $\rho$ was between continuance organizational commitment and attitudinal organizational commitment. The lowest $\rho$ was between normative organizational commitment and calculative organizational commitment.

It is apparent that there is great discrepancy among the results in this table. Firstly, one must be wary of results for meta-analyses with three or fewer estimates. (They were conducted here solely for the sake of thoroughness.) These results must be interpreted with caution. Secondly, three cells of interest are incomplete. This means that there were no studies that tested, i.e., the correlation between attitudinal organizational commitment and affective organizational commitment. (Please note that each cell is incomplete with regard to the relationship between organizational commitment and each of its subdimensions, as these relationships were not tested.) 
Ignoring the incomplete cells as well as those with three or fewer estimates, RBAR varies from .05 to .48 and $\rho$ ranges from .07 to .60 . The weakest correlation is between affective organizational commitment and continuance organizational commitment. The strongest correlation is between affective organizational commitment and normative organizational commitment.

Table 13 depicts the meta-analytic results for job involvement and CPO. Job involvement is a monolithic dimension, so we are only concerned with CPO subdimensions here. Interestingly, there are a number of incomplete cells. And, the three cells that are not vacant have three or fewer estimates. Hence, these results must be viewed with caution. The sample size ranges from 835 to 9,875 . RBAR varies from .21 to .41 , and $\rho$ ranges from. 26 to .50 . The weakest correlation is between continuance occupational commitment and normative occupational commitment. The strongest correlation is between affective occupational commitment and normative occupational commitment.

The meta-analytic results for the work ethic endorsement subdimensions are found in Table 14. Of the three cells of interest, there is one incomplete cell (i.e., for the correlation between work ethic and work involvement). The number of estimates range from four to nine. The sample size varies from 641 to 3,436 . The relationship between PWE and work ethic has an RBAR of .51 and $\rho$ of .72. The relationship between PWE and work involvement has an RBAR of .34 and $\rho$ of .46 .

The last meta-analytic table to be discussed in this section is that of union commitment. All of the cells of interest are filled here. The number of estimates range 
from 20 to 25 . The sample size varies from 7,517 to 12,300 . The lowest RBAR value is .36 while the highest RBAR is .55 . The true score correlation ranges from .45 to .66 .

\section{E. Testing the Hypotheses}

Originally, the three outcome variables of interest were job satisfaction, job performance, and turnover. However, turnover intent was added as a separate construct during coding, since there were so many articles that differentiated between turnover and turnover intent. (Withdrawal intentions and cognitions were included as turnover intent. Thus, turnover intent included terms like thoughts of quitting, search intentions, and quit decisions.)

The meta-analytic results of the 24 work commitment terms with the respective four outcome variables (i.e., job satisfaction, job performance, turnover, and turnover intent) are found in tables $16,17,18$, and 19. Table 16 looks at the meta-analytic results of work commitment and organizational commitment with the outcome variables. Table 17 analyzes the relationship between job involvement and CPO and the outcome variables. Table 18 depicts the results between work ethic endorsement variables and the outcome variables. Finally, Table 19 shows the meta-analytic results for union commitment with the outcome variables.

The number of estimates here ranged from as low as one to as high as 776 . The sample size varied from 48 to 452,688 . Specific RBAR and $\rho$ comparisons are made as each hypothesis is analyzed (later in this chapter).

Tables 20 through 25 depict the meta-analytic results of the relationships between the various work commitment terms. For instance, Table 20 contains the results of the 
meta-analyses of organizational commitment with job involvement and CPO. Table 21 portrays the meta-analytic results of organizational commitment variables with work ethic endorsement variables. Table 22 looks at organizational commitment and union commitment terms. Table 23 shows the meta-analytic results for job involvement and CPO with work ethic endorsement variables. Table 24 reflects the relationships between job involvement and CPO with union commitment variables. Lastly, Table 25 portrays the meta-analytic results for work ethic endorsement and union commitment variables.

It is interesting to note the scattering of incomplete cells across the respective tables. Specifically, of the 194 cells of interest, 124 are incomplete. Further, 42 of the remaining 70 cells have three or fewer indicators. With the above in mind, the number of estimates ranged from one to 137 . Sample size varied from 48 to 45,934 . Specific RBAR and $\rho$ comparisons are made as each hypothesis is analyzed.

\section{Hypothesis 1}

Hypothesis 1 states that the subdimensions of organizational commitment will be positively correlated. This hypothesis is first tested by analyzing the various confidence intervals and then by employing factor analysis. Overall, this hypothesis is only partially supported since there is not enough evidence to indicate that all five variables are intercorrelated.

\section{a. Testing of Confidence Intervals}

Since there are five subdimensions, there are 10 correlations of interest here. Three of these cells are incomplete. (Please see Table 12.) Therefore, the results are inconclusive for the correlations between: (1) attitudinal organizational commitment and 
affective organizational commitment, (2) attitudinal organizational commitment and normative organizational commitment, and (3) calculative organizational commitment and continuance organizational commitment.

The confidence intervals range from -.50 to .86 throughout the various cells. There is enough evidence to indicate that affective organizational commitment is positively correlated with normative organizational commitment, since the true score correlation $(\rho)$ is .60 . The $95 \%$ confidence interval ranges from .34 to .86 here. The confidence interval does not include zero, so there appears to be a significant direct effect.

Three other cells also provide evidence of intercorrelation, since the confidence interval in each respective case excludes zero. The concern, though, is that these three cells contain three or fewer indicators. Hence, such results must be viewed with caution. The positive correlations are between these variables: (1) attitudinal organizational commitment and calculative organizational commitment, (2) attitudinal organizational commitment and continuance organizational commitment, and (3) calculative organizational commitment and normative organizational commitment.

Finally, there is not enough evidence to indicate that affective organizational commitment is positively correlated with continuance organizational commitment or that continuance organizational commitment is positively correlated with normative organizational commitment. This is because, in both instances, the credibility interval includes zero. The correlation between calculative organizational commitment and affective organizational commitment is also not supported; however, there are only three indicators here, so these results must be viewed with caution. 
b. Use of Factor Analysis

In the factor analysis, the first factor explains $43.13 \%$ of the variance. The eigenvalue is 2.16 . The root mean square residual is .2283 . All of the residuals are between -.32 and .28 . The second factor has an eigenvalue of 1.37 and explains $27.45 \%$ of the variance. Support for a one factor model is, therefore, equivocal. While there is a strong general factor, there is also evidence in support of a second factor. The third factor accounts for $16.32 \%$ of the variance, while the fourth factor explains $7.41 \%$ of the variance. The third and fourth factors have eigenvalues less than one. Attitudinal and continuance organizational commitment have high loadings on the first factor. Affective and normative organizational commitment have high loadings on the second factor. And, calculative organizational commitment is strongly loaded on the third factor.

\section{Hypothesis 2}

Hypothesis 2 states that organizational commitment and its five subdimensions will be positively correlated with job satisfaction and job performance while being negatively correlated with turnover. (Please refer to Table 16.) Hypothesis 2 is only partially supported. In general, organizational commitment and its subdimensions are positively correlated with job satisfaction but are not significantly correlated with job performance. It also appears that, overall, the organizational commitment variables are negatively correlated with turnover and with turnover intent. Specific details are recounted below:

Organizational commitment and four of the five subdimensions do provide enough evidence to indicate that they are correlated with job satisfaction. The lowest true score correlation $(\rho)$ among the five constructs is .37 (for the two respective relationships 
between job satisfaction and calculative and normative organizational commitment), while the highest $\rho$ here is .70 (for the correlation between job satisfaction and attitudinal organizational commitment). The confidence intervals range from a low of .11 to a high of 1.12. The only correlation that includes zero in its confidence interval is that of continuance organizational commitment with job satisfaction. Hence, in general, organizational commitment and its subdimensions are positively correlated with job satisfaction.

With regard to job performance, the confidence intervals range from -.63 to .57 . Five of the six confidence intervals include zero, thus not providing enough evidence to indicate that they are positively correlated with performance. However, there is enough evidence to indicate that the correlation between normative organizational commitment and job performance is significant, since that credibility interval does not include zero.

There is enough evidence to indicate that turnover is negatively correlated with three of the six constructs of interest. (There is an incomplete cell for the correlation between calculative organizational commitment and turnover. There are also two cells with three indicators.) The credibility intervals range from -.53 to .21 . The three intervals that do not include zero are those for correlations between turnover and organizational commitment, attitudinal organizational commitment, and normative organizational commitment, respectively. There is evidence in support of a negative correlation here. (Please note, however, that attitudinal and normative organizational commitment have only three indicators, so these results must be viewed with caution.) The confidence intervals between turnover and affective and continuance organizational commitment, 
respectively, do include zero. Hence, there is not enough evidence to indicate that there is a negative relationship between these variables and turnover.

Regarding turnover intent, there is enough evidence to indicate that four of the six constructs are negatively related to turnover intent. This is because their confidence intervals exclude zero. The confidence interval here ranges from -.91 to .13 . The confidence interval for the relationships between calculative and continuance organizational commitment and turnover intent, do include zero, indicating that there is not enough evidence to state that those two sets of variables are negatively correlated.

\section{Hypothesis 3}

Hypothesis 3 states that the type of organization (either public or private) will act as a moderator in the organizational commitment-job satisfaction relationship, such that the relationship will be stronger for employees in a private organization. Hypothesis 3 is not supported.

As indicated in the methods section, when testing for moderators, organizational commitment and its subdimensions are collapsed into one group, labeled organizational commitment. The organizational commitment-job satisfaction correlation is split into two distributions, one for private organizations and one for public organizations. The $95 \%$ confidence interval for the correlations between organizational commitment and job satisfaction for private organizations ranges from .15 to 1.01 . The confidence interval for that of public organizations varies from .23 to .92 . Since the confidence intervals overlap, there is not enough evidence to support a moderator effect here. 


\section{Hypothesis $4 a$}

Hypothesis 4a states that age will serve as a moderator in the (a) organizational commitment-job performance relationship, such that the relationship will be stronger for older employees and in the (b) organizational commitment-turnover relationship, such that the relationship will be stronger for younger employees. Hypothesis 4a is not supported.

The confidence interval for the reported correlations between organizational commitment and performance, involving the older sample, ranges from -.23 to .51 . The confidence interval for the younger sample ranges from -.11 to .45 . Since there is overlap of the confidence intervals, there is not enough evidence to support a moderator effect here. Similarly, the confidence intervals for the older and younger distributions of the organizational commitment-turnover and -turnover intent relationships also overlap. Specifically, the confidence interval for the older sample concerning the organizational commitment-turnover correlations varies from -.47 to .05 , while the confidence interval for the younger sample ranges from -.51 to -.01 . And, with the organizational commitment-turnover intent relationship, the older distribution's confidence interval ranges from -.90 to -.06 , while the younger distribution's confidence interval varies from .89 to -.23 . Hence, there is no evidence of moderator effects.

\section{Hypothesis $4 b$}

Hypothesis $4 \mathrm{~b}$ states that tenure will serve as a moderator in the (a) organizational commitment-job performance relationship, such that the relationship will be stronger for more tenured employees and in the (b) organizational commitment-turnover relationship, 
such that the relationship will be stronger for those with less tenure. Hypothesis $4 \mathrm{~b}$ is not supported.

The organizational commitment-job performance correlations are divided into two distributions, one for more tenured and one for less tenured individuals. The confidence interval for the more tenured group varies from -.24 to .52 , while the confidence interval for the less tenured group ranges from -.22 to .48 . Since there is overlap among the confidence intervals, there is not enough evidence to support a moderator effect.

With the organizational commitment-turnover and -turnover intent relationships, the confidence intervals also overlap. Specifically, with the organizational commitmentturnover correlation, the more tenured distribution has a confidence interval of -.45 to .09. The less tenured distribution's confidence interval ranges from -.55 to .05 . And, with organizational commitment-turnover intent, the more tenured distribution has a confidence interval of -.86 to -.12 . The less tenured group has a confidence interval that ranges from -.97 to -.19 . Again, since there is overlap among the confidence intervals, there is no evidence of a moderator effect here.

\section{Hypothesis 5}

Hypothesis 5 states that type of job (blue-collar versus white-collar) will act as a moderator in the organizational commitment-turnover relationship, such that the relationship will be stronger for those with white-collar jobs. Hypothesis 5 is not supported.

The confidence interval for the blue-collar distribution of the organizational commitment-turnover relationship ranges from -.26 to -.08 . The white-collar distribution 
has a confidence interval which varies from -.49 to .03 . The overlap in the confidence intervals indicate that there is not enough evidence to support a moderator effect here. Similarly, there is overlap in the confidence intervals of the blue- and white-collar distributions of the organizational commitment-turnover intent correlations, indicating that there is no moderator effect there, either. The confidence interval for the blue-collared distribution ranges from -.77 to -.37 . The confidence interval for the while-collar group ranges from -.93 to -.09 .

\section{Hypothesis 6}

Hypothesis 6 states that job involvement will be positively correlated with job satisfaction but will not be significantly correlated with either job performance or turnover. (Please see Table 17.) Hypothesis 6 is only partially supported. There is not enough evidence to indicate that job involvement is positively correlated with job satisfaction, since the confidence interval varies from -.15 to .83 , including zero. This finding runs counter to part of the hypothesis. However, the magnitude and direction of the correlation is as hypothesized. There is also not enough evidence to indicate that job involvement is positively correlated with performance or negatively correlated with turnover. This is because the confidence interval includes zero in both instances. These findings are in concert with the hypothesis. There is evidence, however, of a significant negative relationship between job involvement and turnover intent, since the credibility interval is from -.56 to -.04 , excluding zero. This finding runs counter to the hypothesis. 


\section{Hypothesis 7}

Hypothesis 7 states that type of organization (e.g., private versus public) will act as a moderator in the: (a) job involvement-job satisfaction relationship, such that the relationship will be stronger for employees in private organizations; (b) job involvementjob performance relationship, such that the relationship will be stronger for employees in private organizations; and (c) job involvement-turnover relationship, such that the relationship will be stronger for employees in public organizations. Hypothesis 7 is not supported.

The job involvement- job satisfaction correlations are divided into two distributions, one for public organizations and one for private organizations. The confidence interval for the public organization distribution ranges from -.06 to .74 . The confidence interval for the private company distribution varies from .06 to .70 . Since the two sets of confidence intervals overlap, there is not enough evidence to support a moderator effect. However, the magnitude of the correlations are as hypothesized.

The same circumstances also apply to the confidence intervals concerning the public and private company distributions of the correlations between job involvement and performance, turnover, and turnover intent, respectively. Concerning the private company distribution of the job involvement-performance correlations, the confidence interval ranges from -.03 to .33 . The distribution for the public organization ranges from -.24 to .54. Similarly, with regard to the job involvement-turnover relationship, the confidence interval for private companies ranges from -.22 to -.08 , while the confidence interval for public organizations varies from-.66 to .26 . And, for the job involvement-turnover intent 
correlations, the confidence interval for the private distribution ranges from -.54 to -.04 , while it varies from -.48 to -.12 for the public distribution. In each of these respective instances, the confidence intervals overlap, indicating that there is not enough evidence to support the hypothesized moderator effects.

\section{Hypothesis 8}

Hypothesis 8 states that job involvement will be positively correlated with organizational commitment. (Please refer to Table 20.) This hypothesis is only partially supported, since there is not enough evidence to indicate that all of the subdimensions of organizational commitment are related to job involvement. The confidence intervals range from -.21 to 1.19 . There is enough evidence to indicate that job involvement is positively correlated with organizational commitment, attitudinal organizational commitment, calculative organizational commitment, and normative organizational commitment, since the confidence intervals in each case exclude zero. (The highest $\rho$ here is .52 for the normative organizational commitment- job involvement relationship. The lowest $\rho$ here is .13 for the calculative organizational commitment-job involvement relationship.) However, the confidence intervals include zero for the relationships between job involvement and affective and continuance organizational commitment, respectively. Hence, there is not enough evidence to support a positive correlation between those variables and job involvement.

\section{Hypothesis 9}

Hypothesis 9 states that the six subdimensions of CPO will be positively correlated. First, testing by confidence intervals is explored. Then, the use of factor 
analysis is discussed. Overall, this hypothesis is only partially supported since there is not enough evidence to indicate that all six variables are intercorrelated.

\section{a. Testing of Confidence Intervals}

There are six subdimensions, so there are 15 correlations of interest here. (Please refer to Table 13.) Twelve of the cells are incomplete, leaving only three left to analyze. It is important to note that each of the remaining cells has three or fewer indicators. This means that the results must be viewed with caution. The $\rho$ 's are .46 and .50 for the relationships between affective occupational commitment and continuance and normative occupational commitment, respectively. The true score correlation $(\rho)$ is .26 for the relationship between continuance occupational commitment and normative occupational commitment. The confidence intervals range from .14 to .78 . for the respective correlations between the three variables. In each case, the confidence interval excludes zero, indicating that the three variables are intercorrelated. The positive manifold of the correlations does indicate the presence of a common factor across these subdimensions.

\section{b. Use of Factor Analysis}

Since there were only three out of the possible 15 correlations available for analysis, factor analysis was not conducted.

\section{Hypothesis 10}

Hypothesis 10 states that $\mathrm{CPO}$ and its subdimensions will be positively correlated with job satisfaction and job performance. (Please see Table 17). Hypothesis 10 is only partially supported. Overall, CPO and its subdimensions are positively correlated with job 
satisfaction but the results are inconclusive with regard to job performance. Specific details are given below:

There is enough evidence to indicate that career salience, professionalism, affective occupational commitment, and normative occupational commitment are positively correlated with job satisfaction, since their confidence intervals exclude zero. (Please note that the normative occupational commitment cell has only two indicators.) The lowest true score correlation ( $\rho$ ) among these four constructs is .24 (for the respective relationship between job satisfaction and professionalism), while the highest $\rho$ here is .59 (for the correlation between job satisfaction and affective occupational commitment).

Regarding all seven constructs of interest, the confidence intervals range from a low of -.15 to a high of .98 . It is interesting to note here that $\mathrm{CPO}$ has a $\rho$ of .40 with job satisfaction. Its confidence interval ranges from -.01 to .80 . So, this confidence interval just misses the cutoff to be considered as evidence of a positive relationship. The confidence interval for the career involvement-job satisfaction relationship also includes zero, indicating that there is not enough evidence to show that there is a positive relationship here. Finally, the confidence interval for continuance occupational commitment and job satisfaction does not include zero. However, the true score correlation here is -.15 , indicating a negative relationship between the two variables. This does not support the hypothesis. It is important to mention here that this cell only has two indicators, so its results must be viewed with caution.

With regard to job performance, there are two incomplete cells. Of the remaining five cells, four have indicators of three or fewer. The only one that has more than three 
indicators is the CPO cell. The confidence intervals range from -.15 to .19 . There is enough evidence to indicate that $\mathrm{CPO}$ and affective occupational commitment are positively correlated with job performance, since their confidence intervals do not include zero. There is not enough evidence to indicate that career salience is positively correlated with job performance, since its credibility interval includes zero. And, there is evidence in support of a negative relationship between job performance and continuance and normative occupational commitment, respectively. This runs counter to the hypothesis. However, all of these results, except for those involving CPO must be viewed with caution due to the low number of indicators, as mentioned above.

\section{Hypothesis 11}

Hypothesis 11 states that locus of control (e.g., internal or external) will act as a moderator in the (a) CPO-job satisfaction relationship, such that the relationship will be stronger for employees with an internal locus of control, and (b) CPO-job performance, such that the relationship will be stronger for employees with an internal locus of control. This hypothesis was unable to be tested, as explained in the beginning of this chapter.

XIII. Hypothesis 12

Hypothesis 12 states that age will serve as a moderator of the (a) CPO-job satisfaction relationship, such that the relationship will be stronger for older employees, and (b) CPO-job performance relationship, such that the relationship will be stronger for older employees. Hypothesis 12 is not supported.

In both instances, the correlations are divided into two distributions, one for older and one for younger employees. With the $\mathrm{CPO}$-job satisfaction relationship, the older 
distribution has a confidence interval of -.05 to .85 while the younger group has a distribution of -.05 to .71 . Since there is overlap in the confidence intervals, there is not enough evidence to support a moderator effect. Similarly, there is overlap of the confidence intervals in the two distributions for the CPO-performance relationship. Hence, there is not enough evidence to support a moderator effect here.

XIV. Hypothesis 13

Hypothesis 13 states that $\mathrm{CPO}$ will be positively correlated with organizational commitment and with job involvement. (Please refer to Tables 20 and 13). This hypothesis is only partially supported. In general, organizational commitment and its subdimensions are positively correlated with $\mathrm{CPO}$ and its subdimensions. And, job involvement is positively correlated with $\mathrm{CPO}$ and its subdimensions. The reason this hypothesis is only partially supported is because not all of the cells of interest are complete and because there are certain cells that do not support the hypothesis, as explained below. There are six organizational commitment constructs and seven CPO constructs of interest. Hence, there are 42 potential relationships to consider in the first part of this hypothesis. Of these, 21 are incomplete cells. Additionally, 15 of the remaining cells have three or fewer indicators. So, the results must be reviewed with caution. For the organizational commitment and CPO terms, the confidence intervals range from -.67 to 1.3. The highest $\rho$ is .99 and the lowest $\rho$ is -.25 .

The confidence intervals exclude zero (indicating a positive relationship) for the following pairs of variables: (1) organizational commitment with $\mathrm{CPO}$, career salience, and career involvement; (2) attitudinal organizational commitment with $\mathrm{CPO}$; (3) affective 
organizational commitment with $\mathrm{CPO}$, professionalism, affective occupational

commitment, continuance occupational commitment, and normative occupational

commitment; (4) continuance organizational commitment with continuance occupational

commitment, and normative occupational commitment; and (5) normative organizational

commitment with $\mathrm{CPO}$, affective occupational commitment, continuance occupational

commitment, and normative occupational commitment.

There is not enough evidence to indicate that organizational commitment is positively correlated with professionalism or that normative organizational commitment is positively correlated with career salience. Additionally, there is not enough evidence to indicate that either continuance or calculative organizational commitment is negatively correlated with CPO. (While there are negative true score correlations reported here, the confidence intervals include zero.) Finally, there is enough evidence to indicate that the correlations between: (1) calculative organizational commitment and career salience, and (2) continuance organizational commitment and affective occupational commitment are negative. This is evident since there is a negative $\rho$ reported, and in both cases, since the confidence interval excludes zero. It is important to note that these two cells have two or fewer indicators each. This greatly affects the level of importance that we should place on such results.

With regard to job involvement and its relationship to CPO and its subdimensions, there are seven potential cells of interest. Two of these cells are incomplete. Of the remaining five, three have two or fewer indicators. Hence, the results must be interpreted with caution. The confidence intervals range from -.01 to .94 . The lowest reported $\rho$ was 
.43 and the highest was .68 . There is enough evidence to indicate that job involvement is positively correlated with career salience, career involvement, professionalism, and affective occupational commitment, since the respective confidence intervals exclude zero. Interestingly, the confidence interval for the correlation between job involvement and CPO is from -.01 to .87 . So, this confidence interval just misses the cutoff to be considered in support of the hypothesis.

\section{Hypothesis 14}

Hypothesis 14 states that the subdimensions of work ethic endorsement will be positively correlated. This hypothesis is first tested by analyzing the various confidence intervals and then by employing factor analysis. Overall, this hypothesis is generally supported, although there is not enough evidence to indicate that all three variables are intercorrelated when testing confidence intervals. Also, employment commitment was dropped from the analysis, for reasons mentioned above.

\section{a. Testing of Confidence Intervals}

Since there are three subdimensions, there are three correlations of interest here. One of these cells is incomplete. (Please see Table 14.) Therefore, the results are inconclusive for the correlations between work ethic and work involvement.

There is enough evidence to indicate that Protestant work ethic endorsement is positively correlated with work ethic and with work involvement, since the true score correlations ( $\rho$ ) are .72 and .46 , respectively. The $95 \%$ confidence intervals range from .25 to .85 here. The confidence intervals do not include zero, so there appear to be significant direct effects. 
In the factor analysis, the first factor explains $70.95 \%$ of the variance. The eigenvalue is 2.13 . The root mean square residual for the one factor model is .2107. All of the residuals are between -.30 and -.06 . The second factor explains $19.78 \%$ of the variance and has an eigenvalue less than one. Based on these results, there is support for a one factor model here.

\section{Hypothesis 15}

Hypothesis 15 states that work ethic endorsement will be positively correlated with job satisfaction and job performance, and negatively correlated with turnover. (Please see Table 18.) This hypothesis is partially supported. In general, work ethic endorsement and its subdimensions are not positively correlated with job satisfaction and are negatively correlated with turnover and turnover intent. With regard to performance, the results are inconclusive. It is important to note that the part of the hypothesis concerning employment commitment was not tested, as explained previously. The specific details of hypothesis testing are depicted below.

Four of the 16 cells of interest are incomplete. Of the remaining 12 cells, five have three or fewer indicators. Hence, these results must be read with caution. Regarding relationships with job satisfaction, the confidence intervals range from -.28 to .47 . There is not enough evidence to indicate that job satisfaction is positively correlated with work ethic endorsement, Protestant work ethic endorsement, or work involvement, since the confidence intervals include zero. There is evidence to support the positive relationship between job satisfaction and work ethic, since the confidence interval does not include 
zero. However, this result must be reviewed with caution, since there are three indicators in the cell.

One of the cells needed to analyze the performance relationships is incomplete. Two of the remaining three provide enough evidence to indicate a positive relationship between performance and work ethic and work involvement, respectively. However, these two cells have only two indicators each. Finally, there is enough evidence to indicate that there is a negative relationship between Protestant work ethic endorsement and performance, since $\rho$ is -.01 and the confidence interval excludes zero. This finding runs counter to the hypothesis. It is important to note here that the true score correlation is not a strong negative correlation.

Of the eight possible cells needed to analyze the relationships between turnover and turnover intent with the work ethic endorsement variables, three of the cells are incomplete. Two of the remaining five cells have two or fewer indicators. Hence, these results must be reviewed with caution. The confidence intervals range from -.56 to .02 . There is enough evidence to indicate that there is a negative relationship between turnover (and turnover intent) with Protestant work ethic endorsement and work involvement, respectively. This is because the $\rho$ 's are negative and the confidence intervals do not include zero. There is not enough evidence to indicate a negative relationship between turnover intent and work ethic endorsement, since $\rho$ is -.27 , while the confidence interval ranges from -.56 to .02 . (Note that .02 just missed the cutoff.) 


\section{Hypothesis 16}

Hypothesis 16 states that age will serve as a moderator in the: (a) work ethic endorsement-job satisfaction relationship, such that the relationship will be stronger for older people; (b) work ethic endorsement-job performance relationship, such that the relationship will be stronger for older people; and (c) work ethic endorsement-turnover relationship, such that the relationship will be stronger for younger people. Overall, Hypothesis 16 was not supported. However, this hypothesis was not fully tested. I was unable to test for a moderator effect for the work ethic endorsement-performance relationship. (There were only nine reported correlations in the dataset for the work ethic endorsement-performance relationship. Of these nine correlations, only seven reported an age. Each of the seven ages fall into the "older person" category. Hence, there is no reason to test for a moderator effect here, since there are no correlations with these two variables that fall in the younger age distribution.) Also, as mentioned above, employment commitment was dropped from the analysis and is, therefore, not tested here.

With work ethic endorsement and job satisfaction, the confidence interval for the older distribution ranges from -.22 to .40 while the confidence interval for the younger distribution ranges from -.08 to .58 . Since there is overlap among the intervals, there is not enough evidence to support a moderator effect here. With regard to work ethic endorsement and turnover, there are only two correlations that fall in the older distribution and only one correlation that falls in the younger distribution. Hence, these results are to be interpreted with caution. In both instances, the standard deviation of the true score correlation equals zero. So, for the older distribution, the confidence interval for the work 
ethic endorsement-turnover relationship does not vary, at -.03 . The confidence interval for the younger distribution does not vary, at -.14 . While these results do support the hypothesis that the relationship between work ethic endorsement and turnover will be stronger for younger than for older people, these results must be interpreted with caution, given the reasons stated above.

Regarding the work ethic endorsement-turnover intent relationship, the confidence interval for the younger distribution varies from -.49 to -.19 , while the older distribution varies from -.36 to -.08 . Since there is overlap among the confidence intervals, there is not enough evidence to support the moderator hypothesis here.

XVIII. Hypothesis 17

Hypothesis 17 states that work ethic endorsement will be positively correlated with organizational commitment, job involvement, and CPO. (Please refer to Tables 21 and 23.) This hypothesis is only partially supported. In general, work ethic endorsement variables are positively correlated with organizational commitment and CPO variables. The relationship between work ethic endorsement variables and job involvement, however, is inconclusive. The reasons for partial support of the hypothesis are explained below.

Since there are five subdimensions of organizational commitment and three subdimensions of work ethic endorsement, there are 24 relationships of interest for the first part of the hypothesis. (Please note that employment commitment has been dropped from the analysis.) Of these 24 cells, 12 cells are incomplete. Further, eight of the remaining 12 cells have three or fewer indicators. So, some of these results must be viewed with caution. The confidence intervals range from .04 to .57 . The true score 
correlation $(\rho)$ varies from .04 (for the calculative organizational commitment- Protestant work ethic endorsement relationship) to .51 (for the affective organizational commitmentwork involvement relationship). All of the 12 cells provide evidence in support of the positive relationship between organizational commitment and work ethic endorsement variables, since each credibility interval does not include zero.

The four cells of interest for job involvement and work ethic endorsement variables are available. However, the confidence intervals vary from -.51 to .65 . There is enough evidence to indicate that job involvement is correlated with work ethic endorsement $(\rho=.49)$ and with Protestant work ethic endorsement $(\rho=.42)$, since their confidence intervals do not include zero. On the other hand, there is not enough evidence to indicate that the relationships of job involvement with work ethic or with work involvement are positive, since their respective credibility intervals include zero. Hence, it is unclear whether or not work ethic endorsement, in general, is positively correlated with job involvement.

With regard to CPO and work ethic endorsement terms, 21 out of the 28 cells of interest are incomplete. Further, of the remaining eight cells, five have indicators of three or fewer. These results, therefore, must be interpreted with caution. Of the available cells, all provide evidence of a positive relationship between work ethic endorsement and job involvement. Specifically, work ethic endorsement is significantly related to $\mathrm{CPO}$, career salience, and career involvement, since the confidence intervals exclude zero. Similarly, Protestant work ethic endorsement is positively correlated with $\mathrm{CPO}$ and career salience. And, CPO is positively related to work ethic and work involvement. 
Hypothesis 18 states that the subdimensions of union commitment will be positively correlated. This hypothesis is first tested by analyzing the various confidence intervals and then by employing factor analysis. Overall, this hypothesis is generally supported, although there is not enough evidence to indicate that all four variables are positively correlated when testing confidence intervals.

\section{a. Testing of Confidence Intervals}

Since there are four subdimensions, there are six correlations of interest here. All of the cells of interest are available. (Please refer to Table 15.) The true score correlations range from .45 (for the loyalty to the union-responsibility to the union relationship) to .66 (for the loyalty to the union-belief in unionism relationship). The confidence intervals range from -.08 to 1.15 . There is enough evidence to indicate that union loyalty is correlated with willingness to work for the union and belief in unionism, since the credibility intervals do not include zero. Similarly, there is enough evidence to determine that responsibility to the union is positively correlated with willingness to work for the union and with belief in unionism. However, there is not enough evidence to indicate that either the (1) union loyalty- responsibility to the union correlation or the (2) belief in unionism- willingness to work for the union correlation is positively correlated. This is because their respective credibility intervals include zero. It is important to note that in both cases, though, the lower end of the credibility interval is very weak (i.e., -.08, $-.01)$. 


\section{b. Use of Factor Analysis}

With the union commitment subdimensions, the first factor explains $67.41 \%$ of the variance. The eigenvalue is 2.70 . The root mean square residual is .1253 . All of the residuals fall between -.21 and -.03 . The second and third factors explain $14.26 \%$ and $11.90 \%$, respectively. The eigenvalues for these two factors are less than one. Based on these results, there is evidence in support of a one factor model here.

\section{Hypothesis 19}

Hypothesis 19 states that union commitment and its subdimensions will be negatively correlated with job satisfaction and will not be significantly correlated with job performance. (Please see Table 19.) The hypothesis is only partially supported, and, even then, the results are rather inconclusive. Details of the analysis are described below.

In the instance of job satisfaction, all of the needed cells are available. The credibility intervals range from -.55 to .31 . With the job satisfaction-union commitment relationship as well as with the job satisfaction-belief in unionism relationship, there is not enough evidence to indicate that there is a negative relationship among the variables. There is also not enough evidence to indicate that job satisfaction is positively correlated with either union loyalty or willingness to work for the union, since the credibility intervals include zero in both instances. However, there is enough evidence to provide support for the negative relationship between job satisfaction and responsibility to the union. Since only one of the five cells support the hypothesis, these results are considered inconclusive.

With regard to performance, only two of the five cells are not vacant. And, both of these cells have only one indicator each. Hence, the results must be interpreted with 
caution. There is enough evidence to indicate that the job performance-union commitment relationship is positively correlated, since $\rho$ is .22 and since the credibility interval does not include zero. There is also enough evidence to indicate that the job performance-union loyalty relationship is negatively related, since $\rho$ is -.01 and the confidence interval does not include zero. Either way, this portion of the hypothesis is not supported.

\section{Hypothesis 20}

Hypothesis 20 states that type of job (e.g., white-collar versus blue-collar) will serve as a moderator in the (a) union commitment-job satisfaction relationship, such that the relationship is stronger for blue-collar employees and in the (b) union commitment-job performance relationship, such that the relationship will be stronger for blue-collar employees. Hypothesis 20 is not supported.

In the union commitment- job satisfaction relationship, the confidence interval for blue-collared workers ranges from -.24 to .42 . The confidence interval for white-collar workers varies from -.49 to .37 . Since there is overlap here, there is not enough evidence to support type of job as a moderator. With regard to the union commitment-job performance relationship, type of job was unable to be tested as a moderator since there was only one correlation of interest with these specific variables.

\section{Hypothesis 21}

Hypothesis 21 states that union commitment will be positively correlated with organizational commitment, job involvement, $\mathrm{CPO}$, and work ethic endorsement. (Please refer to Tables 22,24 , and 25 .) This hypothesis is only partially supported. In general, union commitment is not positively correlated with organizational commitment or with job 
involvement. The relationship between union commitment and work ethic endorsement cannot be tested. However, union commitment is positively correlated with CPO. (Please note that employment commitment was dropped from the analysis.) A detailed description of hypothesis testing is found below:

Organizational commitment has five subdimensions and union commitment has four subdimensions. This means that there are 30 potential relationships of interest here. However, seventeen of the 30 cells of interest are incomplete. Of the 13 remaining cells, eight have indicators of three or fewer. Hence, these results need to be viewed with caution. The credibility intervals for these cells range from -.34 to 62 . The true score correlations $(\rho)$ range from -.22 (for the normative organizational commitment-union commitment relationship) to .33 (for the affective organizational commitment-union commitment relationship).

There is enough evidence to indicate that there is a positive relationship between affective organizational commitment and union commitment, union loyalty, and willingness to work for the union, respectively. (However, all indicators in these cells are three or fewer. This means that we must interpret the respective results with caution.) Similarly, there is enough evidence to indicate that the following relationships are negatively correlated: (1) affective organizational commitment with responsibility to the union, (2) continuance organizational commitment with union loyalty, responsibility to the union, and willingness to the union, (3) normative organizational commitment with union commitment, and (4) organizational commitment with belief in unionism. But, in each instance (other than with the organizational commitment-belief in unionism relationship), 
all cells have three or fewer indicators. Hence, the results depicted here must be interpreted with extreme caution. Finally, there is not enough evidence to indicate that organizational commitment is correlated (either positively or negatively) with union commitment, union loyalty, responsibility to the union, or willingness to work for the union.

With regard to job involvement, one of the needed cells is incomplete. Additionally, three of the remaining four cells have two or fewer indicators. The credibility intervals vary from -1.56 to 1.18 . There is not enough evidence to indicate that the relationship between union commitment and job involvement is negatively correlated. Also, there is not enough evidence to indicate that the relationships of job involvement with union loyalty and belief in unionism are positively correlated. Finally, there is enough evidence to indicate that willingness to work for the union is positively correlated with job involvement $(\rho=.09)$. However, there is only one indicator for that cell. Hence, these results must be interpreted with caution.

Of the 35 cells of interest in the CPO-union commitment relationship, 32 are incomplete. Each of the three remaining cells has three or fewer indicators. So, the results must be interpreted with caution. The confidence intervals range from .25 to .87 . The true score correlation varies from .35 to .56 . There is enough evidence to indicate that the respective correlations between union commitment and $\mathrm{CPO}$ are positive, as are the relationships between affective occupational commitment and both union loyalty and willingness to work for the union. 
Finally, all cells between work ethic endorsement variables and union commitment variables are incomplete. So, this part of the hypothesis cannot be tested. 


\section{CHAPTER V}

\section{Discussion}

Work commitment is an important area of study in the organizational sciences (Mowday et al., 1982). Researchers have explored a number of related dimensions and subdimensions of work commitment (Morrow, 1983, 1993). Previous studies have examined the impact of various dimensions of work commitment on organizational outcomes (cf. Mathieu \& Zajac, 1990; Morrow, 1983, 1993). However, much research has not focused on the specific impact of each work commitment concept or on the interrelationships among the various dimensions and subdimensions (cf. Morrow, 1983).

This dissertation meta-analytically examined the expansive material associated with work commitment. The primary purpose of this study was to (1) cumulate the correlations found among each of the dimensions of work commitment to see which, if any, are intercorrelated, and to (2) determine the impact of work commitment dimensions and subdimensions on specific outcome variables (job satisfaction, job performance, and turnover).

A number of interesting results have stemmed from the 213 separate meta-analyses that were conducted. First, the evidence does not indicate that all of the subdimensions for each respective dimension are positively related. Excluding incomplete cells and cells with three or fewer indicators, the only subdimension that is not positively correlated with its other subdimensions is continuance organizational commitment. Future research might consider revamping the work commitment taxonomy so that all subdimensions that fall within a particular dimension are interrelated. It might be appropriate, therefore, to drop 
continuance organizational commitment from the work commitment taxonomy. Just from the definition alone, it appears that continuance organizational commitment might be better placed along side variables relating to turnover intent. After all, if one is planning on staying with an organization, then he or she is definitely not planning on leaving the organization! Future researchers might also consider dropping employment commitment from the work commitment taxonomy. This is because the definition deals more with how committed one is to being employed than with how committed one is to his or her job or occupation.

Second, while most of the respective dimensions are interrelated, this is not the case across the board. Disregarding incomplete cells and cells with three or fewer indicators, there is no evidence of a significant positive relationship between organizational commitment and union commitment. In fact, the only significant relationship is negative between organizational commitment and belief in unionism. These findings run counter to the results of the recent meta-analysis on the relationship between union commitment and company commitment by Johnson et al. (1999). They found that there is a positive correlation between the two variables, supporting the notion of dual allegiance (e.g., simultaneous commitment to one's organization and union). It is important to note that while not significant in this dissertation, the magnitude and direction of the respective correlations between organizational commitment and union commitment, union loyalty, and willingness to work for the union are related as hypothesized. These findings should be considered in relation to other findings in this area (i.e., Mellor, 1990). 
With regard to the various hypothesized relationships between union commitment and work ethic endorsement variables, all of the cells are incomplete. And, ignoring incomplete cells and cells with three or fewer indicators, there is no evidence of a positive relationship between union commitment and either job involvement or CPO. Overall, these findings support Morrow's (1993) rationale for excluding union commitment from the work commitment taxonomy. Future researchers should develop a new work commitment taxonomy that considers these findings.

Along a similar line, local/cosmopolitanism should be dropped from the taxonomy, since there were only four articles relating this construct to the other dimensions out of all of the articles researched for this dissertation. Further, excluding incomplete cells and cells with three or fewer indicators, there is not enough evidence to indicate that job involvement is positively correlated with affective organizational commitment, continuance organizational commitment, work ethic, or work involvement. Future researchers should look more closely at the relationship between job involvement and organizational commitment and work ethic endorsement.

Additionally, it is interesting to note that the cells for the respective correlations between: (1) attitudinal and affective organizational commitment and (2) calculative and continuance organizational commitment are incomplete and are unable to be tested. This is of particular importance because these subdimensions were left as separate constructs in this dissertation and not combined (i.e., a combination construct of attitudinal and affective organizational commitment) so as to determine their impact on one another. But, 
it appears that researchers opt to use one term or the other in their studies, and do not measure both for sake of comparison.

When considering the relationships between attitudinal organizational commitment and the four outcome variables of interest, attitudinal organizational commitment is positively correlated with job satisfaction $(\rho=.70)$ and negatively correlated with turnover and turnover intent $(\rho=-.19,-.58$, respectively). When comparing affective organizational commitment with the same outcome variables, the results are quite similar in direction and in magnitude. Specifically, affective organizational commitment is positively correlated with job satisfaction $(\rho=.60)$ and is negatively correlated with turnover intent $(\rho=-.58)$. However, while the true score correlation between affective organizational commitment and turnover is negative $(\rho=.16)$, this relationship is not significant. In both instances, the relationships between attitudinal and affective organizational commitment with performance are positive, but they are not significant.

Overall, it appears that the terms attitudinal and affective organizational commitment might be measuring the same construct. However, this is not the case with calculative and continuance organizational commitment. Calculative organizational commitment is significantly correlated with job satisfaction $(\rho=.37)$ but continuance organizational commitment is not significantly correlated with this outcome variable ( $\rho=$ .13). Additionally, while the correlations with the remaining outcome variables are not significant for either calculative or continuance organizational commitment, the relationships differ in magnitude and in direction for the two subdimensions. For instance, while not significantly related, calculative organizational commitment is positively 
correlated with performance $(\rho=.17)$. Continuance organizational commitment is negatively correlated with performance $(\rho=-.18)$. And, although also not significant, the relationship between calculative organizational commitment and turnover intent is strong $(\rho=-.38)$, while it is weaker between continuance organizational commitment and turnover intent $(\rho=-.20)$. It seems that the terms calculative and continuance organizational commitment might be measuring different constructs. Future research might benefit from a more clear distinction between these respective terms.

With regard to additional relationships with outcome variables, some of the results for job involvement were not fully in-line with Brown's (1996) recent meta-analysis on the construct. Brown (1996) indicated that job involvement was significantly correlated with job satisfaction. With 450 indicators and a sample size of 131,246 , there was not enough evidence to support a positive relationship between the two variables in this study. Interestingly, there was also (unexpected) evidence of a significant negative relationship between job involvement and turnover intent.

Another surprising result was that there was, in general, not enough evidence to support the hypothesized positive relationship between organizational commitment (and its respective subdimensions) and job performance. The only significant positive relationship (i.e., normative organizational commitment-job performance) reported a low $\rho$ of .07. Also, it is interesting to note that continuance organizational commitment was not significantly related (either positively or negatively) to any of the outcome variables. Ignoring indicators with three or fewer variables, work ethic endorsement and its subdimensions were not significantly related to job satisfaction. And, aside from the 
relationship between job satisfaction and responsibility to the union, there was no support for the hypothesis that the union commitment dimension and its subdimensions would be negatively related to job satisfaction.

Regarding moderator effects, virtually all of the hypothesized moderator effects were not supported. This is surprising, since the hypotheses were formed based on prior findings from other studies (i.e., Colarelli \& Bishop, 1990; Cohen, 1993a; Cohen \& Hudecek, 1993). There was evidence in support of age as a moderator in the work ethic endorsement-turnover relationship. However, there were only two indicators for the olderaged subgroup and only one indicator for the younger-aged subgroup. So, these results must be viewed with caution.

All moderators were tested at the $95 \%$ level since that is the conventional standard. However, I also retested for moderator effects by applying a less rigorous standard (i.e., an $80 \%$ confidence interval). Interestingly, the results changed for only one relationship at this relaxed level. Specifically, when applying an $80 \%$ confidence interval, there was evidence in support of age as a moderator of the CPO-performance relationship. However, contrary to the related hypothesis (Hypothesis 12), the correlation between $\mathrm{CPO}$ and performance was stronger for younger employees than for older employees. Given my dataset, I was able to test two alternate models. First, I ran a factor analysis with job involvement, $\mathrm{CPO}$, and the organizational commitment subdimensions. The first factor explained $40.46 \%$ of the variance and had an eigenvalue of 2.83 . The root mean square residual was .1987 . All residuals were between -.37 and .30 . The second factor had an eigenvalue of 1.56 and explained $22.21 \%$ of the variance. The remaining 
four factors had eigenvalues less than one. So, there is evidence in support of a two factor model here. Interestingly, attitudinal organizational commitment, affective organizational commitment, normative organizational commitment, job involvement, and CPO all had high loadings on the first factor. Calculative and continuance organizational commitment had high loadings on the second factor. The results of this two factor model further emphasize the need to clarify the relationship between calculative and continuance organizational commitment. Further, additional research on organizational commitment and its relationship to job involvement and CPO might prove fruitful.

The other alternate model that I tested looked at the relationship between job involvement, $\mathrm{CPO}$, and the work ethic endorsement subdimensions. The first factor explained $51.56 \%$ of the variance and had an eigenvalue of 2.58 . The root mean square residual was .1676. All residuals were between -.31 and .07 . The second factor explained $20.82 \%$ of the variance and had an eigenvalue of 1.04 . The remaining two factors had eigenvalues less than one. Hence, there is evidence in support of a two factor model here. Interestingly, Protestant Work Ethic endorsement, work ethic, work involvement, and job involvement each had high loadings on the first factor. CPO had a high loading on the second factor. Based on these results, it appears that future research should further investigate the relationship between job involvement and work ethic endorsement variables.

There were several limitations in this dissertation, the first of which was that most of the tagged studies were cross-sectional. This meant that we were only given a static snapshot of the relationship between the variables of interest. Longitudinal studies, on the 
other hand, present a dynamic view of how relationships between variables change. Additionally, most of the studies included no experimental manipulation. Hence, that precluded inferences concerning cause-and-effect relationships among the variables.

The generalizability of the results across cultures was also bounded, because of a majority of North American samples. Very few studies encompassed people from other continents. Research shows that people from different cultures might express different perspectives on the same topic (cf. Silverthorne, 2001). Hence, North American findings might not be generalizable to other cultures (Randall, 1993). Future research should take a cross-cultural look at work commitment.

Finally, the 14 tables representing meta-analytic results show that the number of correlations between the five types of work commitment and the outcome variables was robust. However, there were numerous cells with three or fewer indicators used in the analyses. While they were included in this dissertation for sake of thoroughness, in no way should their results be considered without caution. For instance, most of the correlations between organizational commitment (and its subdimensions) and CPO (and its subdimensions) had three or fewer indicators. Future researchers should conduct more research on the respective relationships between these variables.

These findings have several implications for science and practice. By testing different models, we are now more aware of the role that work commitment plays in the workforce. It is apparent that the work commitment taxonomy needs to be revamped, as explained above. From a practical standpoint, it seems that various dimensions of work commitment do have a strong impact on important organizational outcome variables. 
Employers should focus on maintaining and enhancing the work commitment of employees, since their level of commitment greatly impacts their job satisfaction, performance, and turnover.

In conclusion, the results reported here highlight the importance of work commitment and the need to further investigate the work commitment taxonomy. Continued study should facilitate the construction of workplace theories that explain and guide interventions aimed at improving employee commitment and productivity. 
TABLE 1

Work Commitment Terms Adapted from Morrow's $(1983,1993)$ Taxonomy

\begin{tabular}{|l|l|}
\hline DIMENSIONS & SUBDIMENSIONS \\
\hline Work Commitment & \\
\hline Work Ethic Endorsement & Protestant Work Ethic endorsement, work ethic, \\
Work involvement, employment commitment \\
\hline Commitment & $\begin{array}{l}\text { Career salience, career involvement, } \\
\text { local/cosmopolitanism, professionalism }\end{array}$ \\
\hline Job Involvement & Job commitment \\
\hline Organizational Commitment & Calculative commitment, attitudinal commitment, \\
& continuance commitment, affective commitment, \\
& normative commitment \\
\hline Union Commitment & $-\cdots-$ \\
\hline
\end{tabular}


TABLE 2

Additional Work Commitment Terms from the Literature (new terms italicized)

\begin{tabular}{|l|l|l|}
\hline DIMENSIONS & SUBDIMENSIONS & CITE \\
\hline Career/Professional/Occu- & $\begin{array}{l}\text { Affective occupational } \\
\text { commitment, continuance } \\
\text { occupational commitment, } \\
\text { normative occupational } \\
\text { commitment }\end{array}$ & Allen, 2000 \\
& $\begin{array}{l}\text { Union loyalty, responsibility to } \\
\text { the union, willingness to work for } \\
\text { the union, belief in unionism }\end{array}$ & Burt, Thompson, \\
\hline Union Commitment & \& Spiller, 1980 \\
\hline
\end{tabular}


TABLE 3

Proposed Taxonomy of Work Commitment Terms

\begin{tabular}{|c|c|}
\hline DIMENSIONS & SUBDIMENSIONS \\
\hline Work Commitment & \\
\hline Organizational Commitment & $\begin{array}{l}\text { Calculative organizational commitment, } \\
\text { attitudinal organizational commitment, } \\
\text { continuance organizational commitment, } \\
\text { affective organizational commitment, } \\
\text { normative organizational commitment }\end{array}$ \\
\hline Job Involvement & $-\cdots$ \\
\hline $\begin{array}{l}\text { Career/Professional/Occupational } \\
\text { Commitment }\end{array}$ & $\begin{array}{l}\text { Career salience, career involvement, } \\
\text { professionalism, affective occupational } \\
\text { commitment, continuance occupational } \\
\text { commitment, normative occupational } \\
\text { commitment }\end{array}$ \\
\hline Work Ethic Endorsement & $\begin{array}{l}\text { Protestant Work Ethic endorsement, work } \\
\text { ethic, work involvement, employment } \\
\text { commitment }\end{array}$ \\
\hline Union Commitment & $\begin{array}{l}\text { Union loyalty, responsibility to the union, } \\
\text { willingness to work for the union, belief } \\
\text { in unionism }\end{array}$ \\
\hline
\end{tabular}


TABLE 4

Levels of Moderators Used in Study

\begin{tabular}{|l|l|}
\hline MODERATOR & LEVELS \\
\hline Age & $\begin{array}{l}\text { Older }(\geq 35.7 \text { years }), \\
\text { Younger }(\leq 35.6 \text { years })\end{array}$ \\
\hline Tenure & More Tenured $(\geq 7.24$ years), \\
& Less Tenured $(\leq 7.23$ years $)$ \\
\hline Type of Organization & Private, Public \\
\hline Type of Job & Blue-Collar, White-Collar \\
\hline Locus of Control & Internal Locus of Control, External Locus \\
& of Control \\
\hline
\end{tabular}


TABLE 5

Top Measures of Organizational Commitment

\begin{tabular}{|c|c|}
\hline DIMENSION/SUBDIMENSION & MEASURES (frequency in dataset) \\
\hline ORGANIZATIONAL COMMITMENT & $\begin{array}{l}\text { Mowday et al., } 1979(429) \\
\text { Porter et al., } 1974(216) \\
\text { Porter \& Smith, } 1970(100) \\
\text { Mowday et al, } 1982(55) \\
\text { O'Reilly \& Chatman, 1986(20) } \\
\text { Cook \& Wall, } 1980(18) \\
\text { Porter et al., 1976 (17) } \\
\text { Hrebiniak \& Alutto, } 1972(15) \\
\text { Mael, 1988 (9) } \\
\text { Mael \& Ashforth, } 1992(9) \\
\text { Meyer \& Allen, } 1991(6) \\
\text { Alutto et al., 1993 (6) } \\
\text { DeCotiis \& Summers, } 1987(6) \\
\text { Jorde-Bloom, } 1985(5) \\
\text { Steers, 1977 (5) }\end{array}$ \\
\hline $\begin{array}{l}\text { CALCULATIVE ORGANIZATIONAL } \\
\text { COMMITMENT }\end{array}$ & $\begin{array}{l}\text { Hrebiniak \& Alutto, } 1972(11) \\
\text { Alutto et al., } 1973(7)\end{array}$ \\
\hline $\begin{array}{l}\text { ATTITUDINAL ORGANIZATIONAL } \\
\text { COMMIMENT }\end{array}$ & Mowday et al., $1979(9)$ \\
\hline $\begin{array}{l}\text { CONTINUANCE ORGANIZATIONAL } \\
\text { COMMITMENT }\end{array}$ & $\begin{array}{l}\text { Meyer \& Allen, } 1984(54) \\
\text { Allen \& Meyer, } 1990(47) \\
\text { Meyer \& Allen, } 1991(15) \\
\text { Meyer et al., } 1993(9)\end{array}$ \\
\hline $\begin{array}{l}\text { AFFECTIVE ORGANIZATIONAL } \\
\text { COMMITMENT }\end{array}$ & $\begin{array}{l}\text { Meyer \& Allen, } 1984(74) \\
\text { Allen \& Meyer, } 1990(50) \\
\text { Meyer et al., } 1993(15) \\
\text { O'Reilly \& Chatman, } 1986(11) \\
\text { Meyer \& Allen, } 1991(10) \\
\text { Mowday et al., } 1979(9) \\
\text { Mowday et al., } 1982(7) \\
\text { Becker et al., } 1996(5)\end{array}$ \\
\hline $\begin{array}{l}\text { NORMATIVE ORGANIZATIONAL } \\
\text { COMMITMENT }\end{array}$ & $\begin{array}{l}\text { Allen \& Meyer, } 1990(48) \\
\text { Meyer \& Allen, } 1991(10) \\
\text { Wiener \& Vardi, } 1980(6) \\
\text { Meyer et al., } 1993(6)\end{array}$ \\
\hline
\end{tabular}


TABLE 6

Top Measures of Job Involvement

\begin{tabular}{|l|l|}
\hline \multicolumn{1}{|c|}{ DIMENSION } & \multicolumn{1}{|c|}{ MEASURES (frequency in dataset) } \\
\hline \multirow{2}{*}{ JOB INVOL VEMENT } & Lodahl \& Kejner, 1965 (304) \\
& Kanungo, 1982 (144) \\
& Patchen, 1970 (13) \\
& Lawler \& Hall, 1970 (12) \\
& Saleh \& Hosek, 1976(9) \\
& Kanungo, 1979 (6) \\
& Cook et al., 1981 (5) \\
\hline
\end{tabular}


TABLE 7

Top Measures of Career/Professional/Occupational (CPO) Commitment

\begin{tabular}{|c|c|}
\hline DIMENSION/SUBDIMENSION & MEASURES (frequency in dataset) \\
\hline $\mathrm{CPO}$ & $\begin{array}{l}\text { Blau, } 1985(28) \\
\text { Blau, } 1984(8) \\
\text { Blau, } 1988(7) \\
\text { Mowday et al., } 1979(6) \\
\text { Alutto et al., } 1973(5) \\
\text { DeGroot, } 1996(5) \\
\text { Hall, } 1968(5) \\
\text { Regoli \& Poole, } 1980(5)\end{array}$ \\
\hline CAREER SALIENCE & Greenhaus, $1971(7)$ \\
\hline CAREER INVOLVEMENT & Gould, $1979(7)$ \\
\hline PROFESSIONALISM & Hall, $1968(3)$ \\
\hline $\begin{array}{l}\text { AFFECTIVE OCCUPATIONAL } \\
\text { COMMITMENT }\end{array}$ & Blau, $1988(2)$ \\
\hline $\begin{array}{l}\text { CONTINUANCE OCCUPATIONAL } \\
\text { COMMTTMENT }\end{array}$ & Adapted from Meyer et al., 1993 (1) \\
\hline $\begin{array}{l}\text { NORMATIVE OCCUPATIONAL } \\
\text { COMMITMENT }\end{array}$ & Adapted from Meyer et al., 1993 (1) \\
\hline
\end{tabular}


TABLE 8

Top Measures of Work Ethic Endorsement

\begin{tabular}{|l|l|}
\hline \multicolumn{1}{|c|}{ DIMENSION/SUBDIMENSION } & \multicolumn{1}{|c|}{ MEASURES (frequency in dataset) } \\
\hline WORK ETHIC ENDORSEMENT & $\begin{array}{l}\text { Dubin, 1956 (6) } \\
\text { Cook et al., 1981 (5) }\end{array}$ \\
\hline $\begin{array}{l}\text { PROTESTANT WORK ETHIC } \\
\text { ENDORSEMENT }\end{array}$ & $\begin{array}{l}\text { Blood, 1969 (26) } \\
\text { Mirels \& Garrett, 1971 (19) }\end{array}$ \\
\hline WORK ETHIC & Buchholz, 1977(3) \\
\hline WORK INVOLVEMENT & Kanungo, 1982 (16) \\
\hline
\end{tabular}


TABLE 9

Top Measures of Union Commitment

\begin{tabular}{|l|l|}
\hline \multicolumn{1}{|c|}{ DIMENSION/SUBDIMENSION } & MEASURES (frequency in dataset) \\
\hline UNION COMMITMENT & $\begin{array}{l}\text { Gordon et al., 1980 (7) } \\
\text { Gordon et al., 1990(5) }\end{array}$ \\
\hline UNION LOYALTY & Gordon et al., 1980 (33) \\
\hline RESPONSIBILITY TO THE UNION & Gordon et al., 1980 (20) \\
\hline $\begin{array}{l}\text { WILLINGNESS TO WORK FOR THE } \\
\text { UNION }\end{array}$ & Gordon et al., 1980 (20) \\
\hline BELIEF IN UNIONISM & Gordon et al., 1980 (15) \\
\hline
\end{tabular}


TABLE 10

Top Measures of Outcome Variables

\begin{tabular}{|c|c|}
\hline OUTCOME VARIABLE & MEASURES (frequency in dataset) \\
\hline JOB SATISFACTION & 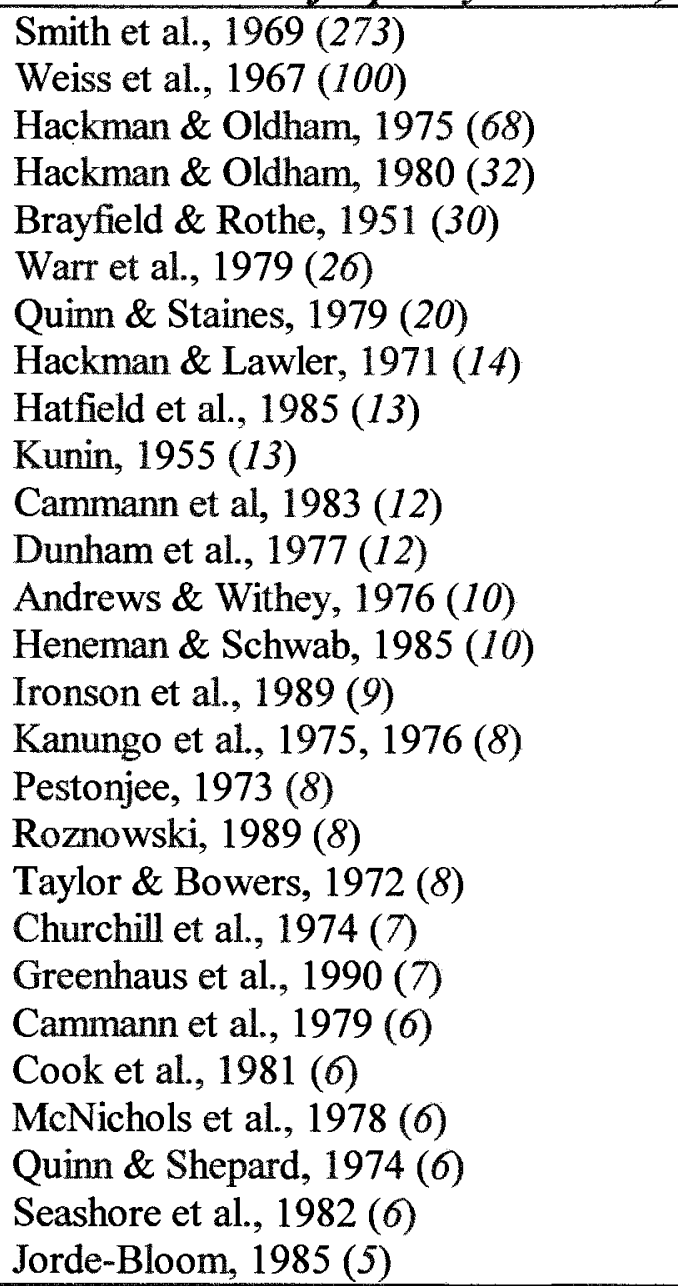 \\
\hline JOB PERFORMANCE & Behrman \& Perreault, 1982 (15) \\
\hline TURNOVER INTENT & $\begin{array}{l}\text { Bluedorn, } 1982(24) \\
\text { Cammann et al., } 1983(17) \\
\text { Cammann et al., } 1979(14) \\
\text { Colarelli, } 1984(11) \\
\text { Mobley, } 1977(11) \\
\text { Mobley et al., } 1979(11) \\
\text { Mobley et al., } 1978(8) \\
\text { Landau \& Hammer, } 1986(6) \\
\text { Lyons, } 1971(6) \\
\text { Seashore et al., } 1982(6) \\
\text { Hanisch \& Hulin, 1990, } 1991(5)\end{array}$ \\
\hline
\end{tabular}


TABLE 11

Reliabilities Table

\begin{tabular}{|c|c|c|c|c|c|c|c|c|c|c|}
\hline Variable & $\boldsymbol{K}$ & $\boldsymbol{N}$ & $\begin{array}{l}\text { Relia } \\
\text { Freqh } \\
\text { Mean }\end{array}$ & $\begin{array}{l}\text { bilities } \\
e n c y \\
S D\end{array}$ & $\begin{array}{l}\text { Relia } \\
\text { Samp } \\
\text { Mean }\end{array}$ & $\begin{array}{l}\text { bilities } \\
\text { Size } \\
\text { SD }\end{array}$ & $\begin{array}{l}\text { Sq. R } \\
\text { Frequ } \\
\text { Mear }\end{array}$ & $\begin{array}{l}\text { oot } \\
\text { ency } \\
\text { SD }\end{array}$ & $\begin{array}{l}\text { Sq. I } \\
\text { Sam } \\
\text { Mea }\end{array}$ & $\begin{array}{l}\text { got } \\
\text { le Size } \\
\text { SD }\end{array}$ \\
\hline $\begin{array}{c}\text { Work } \\
\text { Commitment }\end{array}$ & 4 & 720 & .81 & .0420 & .82 & .0361 & .90 & .0234 & .90 & .0201 \\
\hline $\mathrm{OC}$ & 873 & 423,335 & .85 & .0756 & .85 & .0681 & .92 & .0431 & .92 & .0386 \\
\hline Attitudinal OC & 13 & 4,550 & .85 & .0709 & .83 & .0554 & .92 & .0389 & .91 & .0304 \\
\hline Calculative $\mathrm{OC}$ & 21 & 3,994 & .82 & .0678 & .81 & .0607 & .91 & .0376 & .90 & .0336 \\
\hline Affective OC & 195 & 57,759 & .84 & .0544 & .84 & .0536 & .91 & .0300 & .92 & .0228 \\
\hline $\begin{array}{c}\text { Continuance } \\
\text { OC }\end{array}$ & 128 & 38,134 & .77 & .0662 & .78 & .0584 & .88 & .0382 & .88 & .0334 \\
\hline Normative OC & 59 & 18,550 & .74 & .0703 & .75 & .0586 & .86 & .0413 & .86 & .0341 \\
\hline $\begin{array}{c}\text { Job } \\
\text { Involvement }\end{array}$ & 455 & 151,413 & .78 & .0890 & .76 & .1037 & .88 & .0520 & .87 & .0618 \\
\hline $\mathrm{CPO}$ & 133 & 39,946 & .81 & .0979 & & .1051 & .90 & .0565 & .89 & .0623 \\
\hline Career Salience & 10 & 2,590 & .71 & .1006 & .68 & .1023 & .84 & .0601 & .82 & .0620 \\
\hline $\begin{array}{c}\text { Career } \\
\text { Involvement }\end{array}$ & 7 & 2,829 & & .0472 & .74 & .0441 & .86 & .0272 & .86 & .0253 \\
\hline Prof. & 8 & 1,657 & .72 & .0625 & .70 & .0611 & .85 & .0378 & .84 & .0372 \\
\hline Affective Occ. & 11 & 3,276 & .85 & .0340 & .85 & .0316 & .92 & .0185 & .92 & .0172 \\
\hline $\begin{array}{c}\text { Continuance } \\
\text { Occ. }\end{array}$ & 7 & 2,670 & .83 & .0658 & .81 & .0567 & .91 & .0358 & .90 & .0312 \\
\hline Normative Occ. & 7 & 2,670 & .82 & .0759 & .81 & .0593 & .91 & .0413 & .90 & .0324 \\
\hline $\begin{array}{c}\mathrm{WE} \\
\text { Endorsement }\end{array}$ & 19 & 20,357 & .72 & .0879 & .75 & .0719 & .85 & .0540 & .86 & .0440 \\
\hline PWE & 32 & 7,831 & .70 & .1272 & .67 & .1272 & .83 & .0841 & .81 & .0838 \\
\hline WE & 8 & 2,069 & .75 & .0756 & .76 & .0847 & .86 & .0435 & .87 & .0484 \\
\hline $\begin{array}{c}\text { Work } \\
\text { Involvement }\end{array}$ & 60 & 28,707 & .77 & .0864 & .79 & .0909 & .88 & .0499 & .89 & .0533 \\
\hline $\begin{array}{c}\text { Union } \\
\text { Commitment }\end{array}$ & 30 & 7,738 & & .0575 & .87 & .0654 & .93 & .0309 & .93 & .0354 \\
\hline Loyalty & 51 & 29,542 & .88 & .0465 & .87 & .0468 & .94 & .0251 & .93 & .0254 \\
\hline Responsibility & 22 & 8,135 & .72 & .0790 & .70 & .0794 & .85 & .0476 & .84 & .0476 \\
\hline Willingness & 21 & 6,195 & .77 & .0876 & .78 & .0737 & .88 & .0517 & .88 & .0432 \\
\hline $\begin{array}{c}\text { Belief in } \\
\text { Unionism } \\
\end{array}$ & 18 & 8,217 & .79 & .1036 & .84 & .0794 & .89 & .0604 & .91 & .0452 \\
\hline Job Satisfaction & 832 & 389,602 & .83 & .0789 & .83 & .0771 & .91 & .0447 & .91 & .0434 \\
\hline Performance & 138 & 28,331 & .85 & .0936 & .84 & .1063 & .92 & .0536 & .91 & .0616 \\
\hline Turnover & 2 & 853 & .85 & .0071 & .85 & .0048 & .92 & .0038 & .92 & .0026 \\
\hline Turnover Intent & 243 & 84,644 & .82 & .0850 & .82 & .0755 & .91 & .0482 & .90 & .0407 \\
\hline
\end{tabular}

Note. $K$, number of reliability estimates used in meta-analysis; $N$, total sample size; Sq. Root, square root of reliability estimates; Frequency, frequency-weighted; Sample Size, sample size-weighted; $S D$, standard deviation; $O C$, organizational commitment; $C P O$, career/professional/occupational commitment; Prof., professionalism; $O c c$., occupational commitment; $W E$, work ethic; $P W E$, Protestant work ethic endorsement. 
TABLE 12

Meta-Analytic Results, Organizational Commitment Variables

\begin{tabular}{|c|c|c|c|c|c|c|}
\hline & $\overline{\mathrm{OC}}$ & $\begin{array}{l}\text { Attitudinal } \\
\text { OC }\end{array}$ & $\begin{array}{l}\text { Calculative } \\
\text { OC }\end{array}$ & $\begin{array}{l}\text { Affective } \\
\text { OC }\end{array}$ & $\begin{array}{l}\text { Continuance } \\
\text { OC }\end{array}$ & $\begin{array}{l}\text { Normative } \\
\text { OC }\end{array}$ \\
\hline OC & $\mathrm{I}$ & & & & & \\
\hline $\begin{array}{l}\text { Attitudinal } \\
\text { OC }\end{array}$ & $\mathrm{I}$ & $\mathrm{I}$ & & & & \\
\hline $\begin{array}{l}\text { Calculative } \\
\text { OC }\end{array}$ & $I$ & $\begin{array}{l}\mathrm{k}=1 \\
\mathrm{~N}=533 \\
\mathrm{RBAR}=.42 \\
\mathrm{SDr}=- \\
\rho=.50 \\
\mathrm{SD} \rho^{-}-\end{array}$ & $I$ & & & \\
\hline Affective $O C$ & $I$ & I & $\begin{array}{l}\mathrm{k}=3 \\
\mathrm{~N}=1,072 \\
\mathrm{RBAR}=.12 \\
\mathrm{SDr}=.2793 \\
\rho=.14 \\
\mathrm{SD} \rho=.3269\end{array}$ & $I$ & & \\
\hline $\begin{array}{l}\text { Continuance } \\
\text { OC }\end{array}$ & $T$ & $\begin{array}{l}k=1 \\
N=138 \\
R B A R=.51 \\
S D r=- \\
\rho=.63 \\
S D \rho=-\end{array}$ & $I$ & $\begin{array}{l}=97 \\
N=27,569 \\
R B A R=.05 \\
S D r=.1694 \\
\rho=.07 \\
S D \rho=.1959\end{array}$ & $I$ & \\
\hline $\begin{array}{l}\text { Normative } \\
\text { OC }\end{array}$ & $I$ & $I$ & $\begin{array}{l}\mathrm{k}=3 \\
\mathrm{~N}=432 \\
\mathrm{RBAR}=.01 \\
\mathrm{SDr}=.0535 \\
\rho=.02 \\
\mathrm{SD} \rho=0\end{array}$ & $\begin{array}{l}\mathrm{k}=34 \\
N=11,846 \\
\mathrm{RBAR}=.48 \\
\mathrm{SDr}=.1174 \\
\rho=.60 \\
S D \rho=.1333\end{array}$ & $\begin{array}{l}\mathrm{k}=33 \\
N=11,788 \\
\mathrm{RBAR}=.13 \\
\mathrm{SDr}=.1079 \\
\rho=.18 \\
\mathrm{SD} \rho=.1234\end{array}$ & $\mathrm{I}$ \\
\hline
\end{tabular}

Note. $\mathrm{OC}$, organizational commitment; $\mathrm{K}$, number of correlations included in the analysis; $N$, total sample size; $R B A R$, sample size weighted mean observed correlation; $S D r$, sample size weighted standard deviation of mean observed correlation; $\rho$, RBAR corrected for unreliability; $S D \rho$, standard deviation of $\rho ; I$, incomplete cell. 
TABLE 13

Meta-Analytic Results, Job Involvement and CPO Variables

\begin{tabular}{|c|c|c|c|c|c|c|c|c|}
\hline & $\begin{array}{l}\text { Job } \\
\text { Involvement } \\
\text { (Inv.) }\end{array}$ & $\mathrm{CPO}$ & $\begin{array}{l}\text { Career } \\
\text { Sal- } \\
\text { ience } \\
\end{array}$ & $\begin{array}{l}\text { Career } \\
\text { Involve- } \\
\text { ment } \\
\end{array}$ & Prof. & $\begin{array}{l}\text { Affective } \\
\text { Occ. }\end{array}$ & $\begin{array}{l}\text { Contin- } \\
\text { uance Occ. }\end{array}$ & $\begin{array}{l}\text { Norm- } \\
\text { ative } \\
\text { Occ. } \\
\end{array}$ \\
\hline Job Inv. & I & & & & & & & \\
\hline CPO & $\begin{array}{l}\mathrm{k}=53 \\
N=14,158 \\
\mathrm{RBAR}=.34 \\
\mathrm{SDr}=.1901 \\
\rho=.43 \\
\mathrm{SD} \rho=.2248\end{array}$ & $I$ & & & & & & \\
\hline $\begin{array}{l}\text { Career } \\
\text { Salience }\end{array}$ & $\begin{array}{l}\mathrm{k}=10 \\
\mathrm{~N}=2,274 \\
\mathrm{RBAR}=.47 \\
\mathrm{SDr}=.1358 \\
\rho=.63 \\
\mathrm{SD} \rho=.1579 \\
\end{array}$ & $I$ & $\mathrm{I}$ & & & & & \\
\hline $\begin{array}{l}\text { Career } \\
\text { In- } \\
\text { volve- } \\
\text { ment }\end{array}$ & $\begin{array}{l}k=2 \\
N=912 \\
R B A R=.51 \\
S D r=.0398 \\
\rho=.68 \\
S D \rho=0 \\
\end{array}$ & I & $T$ & I & & & & \\
\hline Prof. & $\begin{array}{l}\mathrm{K}=1 \\
\mathrm{~N}=325 \\
\mathrm{RBAR}=.41 \\
\mathrm{SDr}=- \\
\rho=.55 \\
\mathrm{SD} \rho=-\end{array}$ & I & $I$ & I & I & & & \\
\hline $\begin{array}{l}\text { Affect- } \\
\text { ive } \\
\text { Occ. }\end{array}$ & \begin{tabular}{l|}
$K=2$ \\
$N=348$ \\
$R B A R=.55$ \\
$S D r=.05$ \\
$\rho=.67$ \\
$S D \rho=0$ \\
\end{tabular} & 1 & I & I & I & $I$ & & \\
\hline $\begin{array}{l}\text { Contin- } \\
\text { uance } \\
\text { Occ. }\end{array}$ & $\mathrm{I}$ & I & I & 1 & I & $\begin{array}{l}\mathrm{k}=3 \\
N=9,875 \\
\mathrm{RBAR}=.39 \\
\mathrm{SDr}=.1411 \\
\rho=.46 \\
\mathrm{SD} \rho=.1643\end{array}$ & I & \\
\hline $\begin{array}{l}\text { Norm- } \\
\text { ative } \\
\text { Occ. }\end{array}$ & $I$ & I & I & I & I & $\begin{array}{l}k=2 \\
N=835 \\
R B A R=.41 \\
S D r=.1209 \\
\rho=.50 \\
S D \rho=.1326\end{array}$ & $\begin{array}{l}k=2 \\
N=835 \\
R B A R=.21 \\
S D r=.0134 \\
\rho=.26 \\
S D \rho=0\end{array}$ & I \\
\hline
\end{tabular}

Note. Please see other tables for descriptions of symbols used. 
TABLE 14

Meta-Analytic Results, Work Ethic Endorsement Variables

\begin{tabular}{|c|c|c|c|c|}
\hline & WE Endorsement & $\begin{array}{l}\text { Protestant WE } \\
\text { Endorsement }\end{array}$ & $\mathbf{W E}$ & $\begin{array}{l}\text { Work } \\
\text { Involvement }\end{array}$ \\
\hline $\begin{array}{l}\text { WE } \\
\text { Endorsement }\end{array}$ & $T$ & & & \\
\hline $\begin{array}{l}\text { Protestant WE } \\
\text { Endorsement }\end{array}$ & I & I & & \\
\hline$\overline{\mathbf{W E}}$ & I & $\begin{array}{l}k=4 \\
N=641 \\
R B A R=.51 \\
S D r=.0946 \\
\rho=.72 \\
S D \rho=.0666\end{array}$ & $I$ & \\
\hline $\begin{array}{l}\text { Work } \\
\text { Involvement }\end{array}$ & I & $\begin{array}{l}\mathrm{k}=9 \\
N=3,436 \\
\mathrm{RBAR}=.34 \\
\mathrm{SDr}=.0999 \\
\rho=.46 \\
\mathrm{SD} \rho=.1083\end{array}$ & I & I \\
\hline
\end{tabular}

Note. $W E$, work ethic; $K$, number of correlations included in the analysis; $N$, total sample size; $R B A R$, sample size weighted mean observed correlation; $S D r$, sample size weighted standard deviation of mean observed correlation; $\rho$, RBAR corrected for unreliability; $S D \rho$, standard deviation of $\rho ; I$, incomplete cell. 
TABLE 15

Meta-Analytic Results, Union Commitment Variables

\begin{tabular}{|c|c|c|c|c|c|}
\hline & $\begin{array}{l}\text { Union } \\
\text { Commitment }\end{array}$ & Loyalty & Responsibility & Willingness & $\begin{array}{l}\text { Belief in } \\
\text { Unionism }\end{array}$ \\
\hline $\begin{array}{l}\text { Union } \\
\text { Commitment }\end{array}$ & $\mathrm{I}$ & & & & \\
\hline Loyalty & $I$ & $\mathrm{I}$ & & & \\
\hline Responsibility & $\mathrm{I}$ & $\begin{array}{l}k=25 \\
N=10,799 \\
R B A R=.36 \\
S D r=.2239 \\
\rho=.45 \\
S D \rho=.2724\end{array}$ & I & & \\
\hline Willingness & $\bar{I}$ & $\begin{array}{l}k=25 \\
N=9,150 \\
R B A R=.51 \\
S D r=.2290 \\
\rho=.62 \\
S D \rho=.2690\end{array}$ & $\begin{array}{l}\mathrm{k}=22 \\
\mathrm{~N}=7,908 \\
\mathrm{RBAR}=.44 \\
\mathrm{SDr}=.1712 \\
\rho=.59 \\
\mathrm{SD} \rho=.2157\end{array}$ & $T$ & \\
\hline $\begin{array}{l}\text { Belief in } \\
\text { Unionism }\end{array}$ & $I$ & $\begin{array}{l}k=25 \\
N=12,300 \\
R B A R=.55 \\
S D r=.1905 \\
\rho=.66 \\
S D \rho=.2181\end{array}$ & $\begin{array}{l}k=20 \\
N=7,517 \\
R B A R=.42 \\
S D r=.2026 \\
\rho=.56 \\
S D \rho=.2557\end{array}$ & $\begin{array}{l}k=20 \\
N=7,612 \\
R B A R=.40 \\
S D r=.2156 \\
\rho=.51 \\
S D \rho=.2645\end{array}$ & I \\
\hline
\end{tabular}

Note. K, number of correlations included in the analysis; N, total sample size; RBAR, sample size weighted mean observed correlation; SDr, sample size weighted standard deviation of mean observed correlation; $\rho, \operatorname{RBAR}$ corrected for unreliability; $\operatorname{SD} \rho$, standard deviation of $\rho$; 1 , incomplete cell. 
TABLE 16

Meta-Analytic Results of Work and Organizational Com. Variables with Outcomes

\begin{tabular}{|c|c|c|c|c|}
\hline & Job Satisfaction & Performance & Turnover & Turnover Intent \\
\hline $\begin{array}{c}\text { Work } \\
\text { Commitment }\end{array}$ & $\begin{array}{l}\mathrm{k}=9 \\
N=2,001 \\
\mathrm{RBAR}=.28 \\
\mathrm{SDr}=.2407 \\
\rho=.34 \\
S D \rho=.2809\end{array}$ & I & $I$ & $\begin{array}{l}\mathrm{k}=1 \\
N=141 \\
\mathrm{RBAR}=-.08 \\
\mathrm{SDr}=- \\
\rho=-.10 \\
\mathrm{SD} \rho=-\end{array}$ \\
\hline $\mathrm{OC}$ & $\begin{array}{l}k=776 \\
N=452,688 \\
R B A R=.50 \\
S D r=.1639 \\
\rho=.59 \\
S D \rho=.1857\end{array}$ & $\begin{array}{l}k=179 \\
N=40,419 \\
R B A R=.15 \\
S D r=.1267 \\
\rho=.17 \\
S D \rho=.1258\end{array}$ & $\begin{array}{l}k=99 \\
N=38,360 \\
R B A R=-.19 \\
S D r=.1088 \\
\rho=-23 \\
S D \rho=.1131\end{array}$ & $\begin{array}{l}\mathrm{k}=316 \\
N=127,243 \\
\mathrm{RBAR}=-.48 \\
\mathrm{SDr}=.1560 \\
\rho^{=-.57} \\
\mathrm{SD} \rho=.1749\end{array}$ \\
\hline Attitudinal OC & $\begin{array}{l}k=11 \\
N=4,535 \\
R B A R=.59 \\
S D r=.1883 \\
\rho=.70 \\
S D \rho=.2146 \\
\end{array}$ & $\begin{array}{l}\mathrm{k}=2 \\
\mathrm{~N}=574 \\
\mathrm{RBAR}=.07 \\
\mathrm{SDr}=.1030 \\
\rho=.08 \\
\mathrm{SD} \rho=.0984\end{array}$ & $\begin{array}{l}\mathrm{k}=3 \\
\mathrm{~N}=781 \\
\mathrm{RBAR}=-.16 \\
\mathrm{SDr}=.0927 \\
\rho=-.19 \\
\mathrm{SD} \rho=.0818\end{array}$ & $\begin{array}{l}\mathrm{k}=6 \\
\mathrm{~N}=3,320 \\
\mathrm{RBAR}=-.48 \\
\mathrm{SDr}=.1151 \\
\rho=-.58 \\
\mathrm{SD} \rho=.1254\end{array}$ \\
\hline Calculative $\mathrm{OC}$ & $\begin{array}{l}\mathrm{k}=11 \\
N=2,298 \\
\mathrm{RBAR}=.31 \\
\mathrm{SDr}=.1302 \\
\rho^{=.37} \\
\mathrm{SD} \rho=.1345\end{array}$ & $\begin{array}{l}k=3 \\
N=835 \\
R B A R=.15 \\
S D r=.1228 \\
\rho=.17 \\
S D \rho=.1268\end{array}$ & $I$ & $\begin{array}{l}\mathrm{k}=4 \\
\mathrm{~N}=1,139 \\
\mathrm{RBAR}=-.28 \\
\mathrm{SDr}=.2218 \\
\rho=-.38 \\
\mathrm{SD} \rho=.2578\end{array}$ \\
\hline Affective OC & $\begin{array}{l}\mathrm{k}=85 \\
N=26,318 \\
\mathrm{RBAR}=.50 \\
S D r=.1333 \\
\rho=.60 \\
S D \rho=.1457\end{array}$ & $\begin{array}{l}\mathrm{k}=43 \\
N=8,633 \\
\mathrm{RBAR}=.19 \\
\mathrm{SDr}=.1685 \\
\rho=.22 \\
S D \rho=.1798\end{array}$ & $\begin{array}{l}k=10 \\
N=3,644 \\
R B A R==.14 \\
S D r=.1690 \\
\rho=-.16 \\
S D \rho=.1891\end{array}$ & $\begin{array}{l}k=62 \\
N=20,950 \\
R B A R=-.48 \\
S D r=.1155 \\
\rho=-.58 \\
S D \rho=.1233\end{array}$ \\
\hline Continuance $\mathrm{OC}$ & $\begin{array}{l}\mathrm{k}=57 \\
\mathrm{~N}=22,716 \\
\mathrm{RBAR}=.10 \\
\mathrm{SDr}=.2264 \\
\rho=.13 \\
\mathrm{SD} \rho=.2739\end{array}$ & $\begin{array}{l}\mathrm{k}=26 \\
N=4,642 \\
\mathrm{RBAR}=-.14 \\
\mathrm{SDr}=.2023 \\
\rho=-.18 \\
\mathrm{SD} \rho=.2304\end{array}$ & $\begin{array}{l}\mathrm{k}=10 \\
N=2,730 \\
\mathrm{RBAR}=-.13 \\
\mathrm{SDr}=.1346 \\
\rho=-.16 \\
\mathrm{SD} \rho=.1481\end{array}$ & $\begin{array}{l}\mathrm{k}=28 \\
\mathrm{~N}=10,807 \\
\mathrm{RBAR}=-.16 \\
\mathrm{SDr}=.1349 \\
\rho=-.20 \\
\mathrm{SD} \rho=.1558\end{array}$ \\
\hline Normative OC & $\begin{array}{l}\mathrm{k}=32 \\
\mathrm{~N}=13,254 \\
\mathrm{RBAR}=.29 \\
\mathrm{SDr}=.0931 \\
\rho=.37 \\
\mathrm{SD} \rho=.0997\end{array}$ & $\begin{array}{l}k=14 \\
N=3,175 \\
R B A R=.05 \\
S D r=.0610 \\
\rho=.07 \\
S D \rho=0\end{array}$ & $\begin{array}{l}\mathrm{k}=3 \\
\mathrm{~N}=1,430 \\
\mathrm{RBAR}=-.17 \\
\mathrm{SDr}=.0602 \\
\rho=-.21 \\
\mathrm{SD} \rho=.0495\end{array}$ & $\begin{array}{l}k=23 \\
N=9,902 \\
R B A R=-.29 \\
S D r=.07 \\
\rho=-.37 \\
S D \rho=.0686\end{array}$ \\
\hline
\end{tabular}

Note. $O C$, organizational commitment; $K$, number of correlations included in the analysis; $N$, total sample size; $R B A R$, sample size weighted mean observed correlation; $S D r$, sample size weighted standard deviation of mean observed correlation; $\rho$, RBAR corrected for unreliability; $S D \rho$, standard deviation of $\rho ; I$, incomplete cell. 
TABLE 17

Meta-Analytic Results of Job Involvement and CPO variables with Outcomes

\begin{tabular}{|c|c|c|c|c|}
\hline & Job Satisfaction & Performance & Turnover & Turnover Intent \\
\hline Job Involvement & $\begin{array}{l}\mathrm{k}=450 \\
N=131,246 \\
\mathrm{RBAR}=.28 \\
\mathrm{SDr}=.2102 \\
\rho=.34 \\
\mathrm{SD} \rho=.2493\end{array}$ & $\begin{array}{l}k=83 \\
N=21,264 \\
R B A R=.14 \\
S D r=.1498 \\
\rho=18 \\
S D \rho=.1658\end{array}$ & $\begin{array}{l}\mathrm{k}=26 \\
\mathrm{~N}=8,713 \\
\mathrm{RBAR}=.13 \\
\mathrm{SDr}=.0964 \\
\rho=.16 \\
\mathrm{SD} \rho=.0973\end{array}$ & $\begin{array}{l}\mathrm{k}=102 \\
\mathrm{~N}=40,054 \\
\mathrm{RBAR}=-.24 \\
\mathrm{SD}=.1179 \\
\rho=-.30 \\
\mathrm{SD} \rho=.1318\end{array}$ \\
\hline CPO & $\begin{array}{l}k=100 \\
N=29,138 \\
R B A R=.33 \\
S D=.1799 \\
\rho=.40 \\
S D \rho=.2054\end{array}$ & $\begin{array}{l}k=16 \\
N=3,226 \\
R B A R=.16 \\
S D r=.0488 \\
\rho=.19 \\
S D \rho=0\end{array}$ & $\begin{array}{l}k=16 \\
N=3,676 \\
R B A R=-.05 \\
S D r=.1274 \\
\rho=-.06 \\
S D \rho=.1303\end{array}$ & $\begin{array}{l}\mathrm{k}=48 \\
\mathrm{~N}=14,860 \\
\mathrm{RBAR}=-.23 \\
\mathrm{SD}=.2219 \\
\rho=-.29 \\
\mathrm{SD} \rho=.2604\end{array}$ \\
\hline Career Salience & $\begin{array}{l}k=5 \\
N=869 \\
R B A R=.22 \\
S D r=.0818 \\
\rho=.29 \\
S D \rho=.0429\end{array}$ & $\begin{array}{l}\mathrm{k}=3 \\
N=446 \\
\mathrm{RBAR}=.01 \\
\mathrm{SDr}=.1046 \\
\rho=.01 \\
\mathrm{SD} \rho=.0821\end{array}$ & $\mathrm{I}$ & $\begin{array}{l}\mathrm{k}=1 \\
N=195 \\
\mathrm{RBAR}=.02 \\
\mathrm{SDr}=- \\
\rho=.03 \\
\mathrm{SD} \rho=-\end{array}$ \\
\hline $\begin{array}{c}\text { Career } \\
\text { Involvement }\end{array}$ & $\begin{array}{l}\mathrm{k}=7 \\
N=2,829 \\
\mathrm{RBAR}=.21 \\
\mathrm{SD}=.1535 \\
\rho=.27 \\
\mathrm{SD} \rho=.1842\end{array}$ & I & I & $\begin{array}{l}k=2 \\
N=912 \\
\text { RBAR=-.16 } \\
\text { SDr }=0 \\
\rho=-.21 \\
S D \rho=0\end{array}$ \\
\hline Professionalism & $\begin{array}{l}k=7 \\
N=1,332 \\
R B A R=.18 \\
S D r=.1053 \\
\rho=.24 \\
S D \rho=.0991\end{array}$ & I & $\begin{array}{l}\mathrm{k}=2 \\
N=607 \\
\mathrm{RBAR}=.03 \\
\mathrm{SDr}=0 \\
\rho=.04 \\
\mathrm{SD} \rho=0\end{array}$ & $\begin{array}{l}\mathrm{k}=2 \\
\mathrm{~N}=607 \\
\mathrm{RBAR}=-.04 \\
\mathrm{SDr}=.1300 \\
\rho=.05 \\
\mathrm{SD} \rho=.1499\end{array}$ \\
\hline Affective Occ. & $\begin{array}{l}k=6 \\
N=1,441 \\
R B A R=.50 \\
S D=.1773 \\
\rho=.59 \\
S D \rho=.1982\end{array}$ & $\begin{array}{l}\mathrm{k}=2 \\
\mathrm{~N}=1,206 \\
\mathrm{RBAR}=.06 \\
\mathrm{SDr}=.0100 \\
\rho=.07 \\
\mathrm{SD} \rho=0\end{array}$ & I & $\begin{array}{l}k=6 \\
N=1,755 \\
R B A R=-39 \\
S D r=.1858 \\
\rho=-.47 \\
S D \rho=.2101\end{array}$ \\
\hline $\begin{array}{c}\text { Continuance } \\
\text { Occ. }\end{array}$ & $\begin{array}{l}\mathrm{k}=2 \\
\mathrm{~N}=835 \\
\mathrm{RBAR}=-.13 \\
\mathrm{SDr}=.0224 \\
\rho=-.15 \\
\mathrm{SD} \rho=0\end{array}$ & $\begin{array}{l}\mathrm{k}=2 \\
\mathrm{~N}=1,206 \\
\mathrm{RBAR}=-.09 \\
\mathrm{SDr}=.0200 \\
\rho=-.11 \\
\mathrm{SD} \rho=0\end{array}$ & I & $\begin{array}{l}k=4 \\
N=1,497 \\
R B A R=.01 \\
S D=.1678 \\
\rho=.01 \\
S D \rho=.1917\end{array}$ \\
\hline Normative Occ. & $\begin{array}{l}k=2 \\
N=835 \\
R B A R=.23 \\
S D r=.0314 \\
\rho=.28 \\
S D \rho=0\end{array}$ & $\begin{array}{l}\mathrm{k}=2 \\
\mathrm{~N}=1,206 \\
\mathrm{RBAR}=-.04 \\
\mathrm{SD}=.0150 \\
\rho=-.04 \\
\mathrm{SD} \rho=0\end{array}$ & I & $\begin{array}{l}k=4 \\
N=1,497 \\
R B A R=-.22 \\
S D r=.1067 \\
\rho=-.27 \\
S D \rho=.1125\end{array}$ \\
\hline
\end{tabular}

Note. Please see other tables for descriptions of symbols used. 
TABLE 18

Meta-Analytic Results of Work Ethic Endorsement Variables and Outcomes

\begin{tabular}{|c|c|c|c|c|}
\hline & Job Satisfaction & Performance & Turnover & Turnover Intent \\
\hline & & & & \\
\hline $\begin{array}{c}\mathrm{WE} \\
\text { Endorsement }\end{array}$ & $\begin{array}{l}k=16 \\
N=48,867 \\
R B A R=.11 \\
S D r=.09 \\
\rho=.15 \\
S D \rho=.1129\end{array}$ & I & 1 & $\begin{array}{l}\mathrm{k}=6 \\
\mathrm{~N}=4,478 \\
\mathrm{RBAR}=-.21 \\
\mathrm{SDr}=.1230 \\
\rho=-.27 \\
\mathrm{SD} \rho=.1503\end{array}$ \\
\hline $\begin{array}{l}\text { Protestant WE } \\
\text { Endorsement }\end{array}$ & $\begin{array}{l}\mathrm{k}=23 \\
\mathrm{~N}=2,940 \\
\mathrm{RBAR}=.17 \\
S D r=.1278 \\
\rho=.23 \\
S D \rho=.1207\end{array}$ & $\begin{array}{l}\mathrm{k}=5 \\
N=856 \\
R B A R=.01 \\
S D r=.0504 \\
\rho=-.01 \\
S D \rho=0\end{array}$ & $\begin{array}{l}\mathrm{k}=1 \\
\mathrm{~N}=145 \\
\mathrm{RBAR}=-.11 \\
\mathrm{SDr}=- \\
\rho=-14 \\
\mathrm{SD} \rho=-\end{array}$ & $\begin{array}{l}\mathrm{k}=5 \\
N=860 \\
\mathrm{RBAR}=-.08 \\
\mathrm{SDr}=.0742 \\
\rho=-.10 \\
\mathrm{SD} \rho=0\end{array}$ \\
\hline WE & $\begin{array}{l}\mathrm{k}=3 \\
\mathrm{~N}=1,081 \\
\mathrm{RBAR}=.15 \\
\mathrm{SDr}=.0234 \\
\rho=.19 \\
\mathrm{SD} \rho=0\end{array}$ & $\begin{array}{l}\mathrm{k}=2 \\
\mathrm{~N}=60 \\
\mathrm{RBAR}=.38 \\
\mathrm{SDr}=.2150 \\
\rho=.47 \\
\mathrm{SD} \rho=.1755\end{array}$ & $I$ & $\mathrm{I}$ \\
\hline $\begin{array}{c}\text { Work } \\
\text { Involvement }\end{array}$ & $\begin{array}{l}\mathrm{k}=36 \\
N=15,932 \\
\mathrm{RBAR}=.07 \\
\mathrm{SDr}=.1577 \\
\rho=.08 \\
\mathrm{SD} \rho=.1858\end{array}$ & $\begin{array}{l}k=2 \\
N=461 \\
R B A R=.06 \\
S D r=0 \\
\rho=.07 \\
S D \rho=0\end{array}$ & $\begin{array}{l}\mathrm{k}=2 \\
\mathrm{~N}=566 \\
\mathrm{RBAR}=-.02 \\
\mathrm{SDr}=0 \\
\rho=-.02 \\
\mathrm{SD} \rho=0\end{array}$ & $\begin{array}{l}\mathrm{k}=7 \\
\mathrm{~N}=3,191 \\
\mathrm{RBAR}=-.17 \\
\mathrm{SDr}=.0568 \\
\rho^{=}=.21 \\
\mathrm{SD} \rho=.0389\end{array}$ \\
\hline
\end{tabular}

Note. $W E$, work ethic; $K$, number of correlations included in the analysis; $N$, total sample size; $R B A R$, sample size weighted mean observed correlation; $S D r$, sample size weighted standard deviation of mean observed correlation; $\rho, \operatorname{RBAR}$ corrected for unreliability; $S D \rho$, standard deviation of $\rho ; I$, incomplete cell. 
TABLE 19

Meta-Analytic Results: Union Commitment Variables and Outcomes

\begin{tabular}{|c|c|c|c|c|}
\hline & Job Satisfaction & Performance & Turnover & Turnover Intent \\
\hline & & & & \\
\hline $\begin{array}{c}\text { Union } \\
\text { Commitment }\end{array}$ & $\begin{array}{l}\mathrm{k}=24 \\
\mathrm{~N}=5,649 \\
\mathrm{RBAR}=-.04 \\
\mathrm{SDr}=.2300 \\
\rho=-.05 \\
\mathrm{SD} \rho=.2569\end{array}$ & $\begin{array}{l}\mathrm{k}=1 \\
N=114 \\
\mathrm{RBAR}=.19 \\
\mathrm{SDr}=- \\
\rho=.22 \\
\mathrm{SD} \rho=-\end{array}$ & $\begin{array}{l}\mathrm{k}=1 \\
N=114 \\
\mathrm{RBAR}=-.08 \\
\mathrm{SDr}=- \\
\rho=-.09 \\
\mathrm{SD} \rho=-\end{array}$ & $\begin{array}{l}\mathrm{k}=1 \\
N=1,167 \\
\mathrm{RBAR}=-.04 \\
\mathrm{SDr}=- \\
\rho=-.05 \\
\mathrm{SD} \rho=-\end{array}$ \\
\hline Loyalty & $\begin{array}{l}\mathrm{k}=30 \\
N=15,552 \\
\mathrm{RBAR}=.10 \\
\mathrm{SDr}=.0944 \\
\rho=.12 \\
\mathrm{SD} \rho=.0969\end{array}$ & $\begin{array}{l}\mathrm{k}=1 \\
\mathrm{~N}=74 \\
\mathrm{RBAR}=-.01 \\
\mathrm{SDr}=- \\
\rho=-.01 \\
\mathrm{SD} \rho=-\end{array}$ & I & $\begin{array}{l}\mathrm{k}=3 \\
\mathrm{~N}=1,344 \\
\mathrm{RBAR}=-.05 \\
\mathrm{SDr}=.0381 \\
\rho=-.06 \\
\mathrm{SD} \rho=0\end{array}$ \\
\hline Responsibility & $\begin{array}{l}k=8 \\
N=1,852 \\
R B A R=-.13 \\
S D r=-.0584 \\
\rho=-.17 \\
S D \rho=0\end{array}$ & $I$ & I & $\begin{array}{l}\mathrm{k}=1 \\
N=48 \\
\mathrm{RBAR}=.08 \\
\mathrm{SDr}=- \\
\rho=.10 \\
\mathrm{SD} \rho=-\end{array}$ \\
\hline Willingness & $\begin{array}{l}\mathrm{k}=12 \\
N=3,277 \\
\mathrm{RBAR}=.02 \\
\mathrm{SDr}=.0811 \\
\rho=.03 \\
\mathrm{SD} \rho=.0667\end{array}$ & I & I & $\begin{array}{l}k=2 \\
N=177 \\
R B A R=-.11 \\
S D r=.0222 \\
\rho=-.14 \\
S D \rho=0\end{array}$ \\
\hline $\begin{array}{l}\text { Belief in } \\
\text { Unionism }\end{array}$ & $\begin{array}{l}k=8 \\
N=1,765 \\
R B A R=-.11 \\
S D r=.1304 \\
\rho=-.14 \\
S D \rho=.1365\end{array}$ & I & I & $\mathrm{I}$ \\
\hline
\end{tabular}

Note. $K$, number of correlations included in the analysis; $N$, total sample size; $R B A R$, sample size weighted mean observed correlation; $S D r$, sample size weighted standard deviation of mean observed correlation; $\rho, \operatorname{RBAR}$ corrected for unreliability; $S D \rho$, standard deviation of $\rho ; I$, incomplete cell. 
TABLE 20

Meta-Analytic Results: Organizational Commitment with Job Involvement, CPO

\begin{tabular}{|c|c|c|c|c|c|c|}
\hline & $\mathrm{OC}$ & $\begin{array}{l}\text { Attitudinal } \\
\text { OC }\end{array}$ & $\begin{array}{l}\text { Calculative } \\
\text { OC } \\
\end{array}$ & Affective $\mathrm{OC}$ & $\begin{array}{l}\text { Contin- } \\
\text { uance OC }\end{array}$ & $\begin{array}{l}\text { Normative } \\
\text { OC }\end{array}$ \\
\hline $\begin{array}{l}\text { Job } \\
\text { Involve- } \\
\text { ment }\end{array}$ & $\begin{array}{l}K=137 \\
N=45,934 \\
R B A R=.42 \\
S D r=.1679 \\
\rho=.51 \\
S D \rho=.1938\end{array}$ & $\begin{array}{l}k=4 \\
N=2,417 \\
\operatorname{RBAR}=.30 \\
S D r=.1394 \\
\rho=.37 \\
S D \rho=.1621\end{array}$ & $\begin{array}{l}\mathrm{k}=5 \\
\mathrm{~N}=842 \\
\mathrm{RBAR}=.11 \\
\mathrm{SDr}=.0860 \\
\rho=.13 \\
\mathrm{SD} \rho=.0480\end{array}$ & $\begin{array}{l}\mathrm{k}=19 \\
N=5,286 \\
\mathrm{RBAR}=.39 \\
\mathrm{SDr}=.2945 \\
\rho=.49 \\
\mathrm{SD} \rho=.3547\end{array}$ & $\begin{array}{l}k=8 \\
N=1,556 \\
R B A R=.15 \\
S D r=.1209 \\
\rho=.19 \\
S D \rho=.1255\end{array}$ & $\begin{array}{l}\mathrm{k}=4 \\
\mathrm{~N}=510 \\
\mathrm{RBAR}=.40 \\
\mathrm{SDr}=.0391 \\
\rho=.52 \\
\mathrm{SD} \rho=0\end{array}$ \\
\hline $\mathrm{CPO}$ & $\begin{array}{l}K=80 \\
N=27,351 \\
R B A R=.35 \\
S D r=.1596 \\
\rho=.42 \\
S D \rho=.1791\end{array}$ & $\begin{array}{l}k=1 \\
N=122 \\
R B A R=.45 \\
S D r=- \\
\rho=.54 \\
S D \rho=.\end{array}$ & $\begin{array}{l}\mathrm{k}=3 \\
\mathrm{~N}=666 \\
\mathrm{RBAR}=-.05 \\
\mathrm{SDr}=.2626 \\
\rho=.07 \\
\mathrm{SD} \rho=.3080\end{array}$ & $\begin{array}{l}k=14 \\
N=5,120 \\
R B A R=.39 \\
S D r=.1381 \\
\rho=.47 \\
S D \rho=.1537\end{array}$ & $\begin{array}{l}k=6 \\
N=1,528 \\
\operatorname{RBAR}=-.07 \\
S D=.1073 \\
\rho=-.09 \\
S D \rho=.1095\end{array}$ & $\begin{array}{l}k=3 \\
N=972 \\
R B A R=.19 \\
S D r=.0582 \\
\rho=.24 \\
S D \rho=.0217\end{array}$ \\
\hline $\begin{array}{l}\text { Career } \\
\text { Salience }\end{array}$ & $\begin{array}{l}K=4 \\
N=1,662 \\
R B A R=.30 \\
S D r=.1237 \\
\rho=.38 \\
S D \rho=.1440 \\
\end{array}$ & $\mathrm{I}$ & $\begin{array}{l}k=2 \\
N=141 \\
\text { RBAR }=-.04 \\
\text { SDr }=.0734 \\
\rho=.05 \\
S D \rho=0\end{array}$ & I & I & $\begin{array}{l}k=2 \\
N=141 \\
R B A R=.09 \\
S D r=.1859 \\
\rho=.13 \\
S D \rho=.1947\end{array}$ \\
\hline $\begin{array}{l}\text { Career } \\
\text { Involve- } \\
\text { ment }\end{array}$ & $\begin{array}{l}K=2 \\
N=912 \\
R B A R=.40 \\
S D r=.0946 \\
\rho=.51 \\
S D \rho=.1042\end{array}$ & $\mathrm{I}$ & I & I & I & 1 \\
\hline Prof. & $\begin{array}{l}K=8 \\
N=1,468 \\
R B A R=.26 \\
S D r=.2178 \\
\rho=.33 \\
S D \rho=.2605 \\
\end{array}$ & I & I & $\begin{array}{l}\mathrm{k}=1 \\
\mathrm{~N}=305 \\
\mathrm{RBAR}=.03 \\
\mathrm{SDr}=- \\
\rho=.04 \\
\mathrm{SD} \rho=-\end{array}$ & I & I \\
\hline $\begin{array}{l}\text { Affective } \\
\text { Occ. }\end{array}$ & I & I & I & $\begin{array}{l}k=7 \\
N=1,779 \\
R B A R=.51 \\
S D=.0883 \\
\rho=.61 \\
S D \rho=.0849\end{array}$ & $\begin{array}{l}\mathrm{k}=1 \\
\mathrm{~N}=603 \\
\mathrm{RBAR}=.20 \\
\mathrm{SDr}=- \\
\rho=.25 \\
\mathrm{SD} \rho=-\end{array}$ & $\begin{array}{l}k=1 \\
N=603 \\
R B A R=.36 \\
S D=- \\
\rho=.45 \\
S D \rho=.\end{array}$ \\
\hline $\begin{array}{l}\text { Contin- } \\
\text { uance } \\
\text { Occ. }\end{array}$ & I & I & I & $\begin{array}{l}k=1 \\
N=603 \\
R B A R=.03 \\
S D r=- \\
\rho=.04 \\
S D \rho=-\end{array}$ & $\begin{array}{l}\mathrm{k}=3 \\
\mathrm{~N}=1,173 \\
\mathrm{RBAR}=.82 \\
\mathrm{SDr}=.0831 \\
\rho=.99 \\
\mathrm{SD} \rho=0 \\
\end{array}$ & $\begin{array}{l}k=1 \\
N=603 \\
R B A R=.12 \\
S D r=- \\
\rho=.15 \\
S D \rho=.\end{array}$ \\
\hline $\begin{array}{l}\text { Normative } \\
\text { Occ. }\end{array}$ & 1 & I & I & $\begin{array}{l}k=1 \\
N=603 \\
R B A R=.33 \\
S D=- \\
\rho=.40 \\
S D \rho=-\end{array}$ & $\begin{array}{l}k=1 \\
N=603 \\
R B A R=.15 \\
S D=- \\
\rho=.19 \\
S D \rho=-\end{array}$ & $\begin{array}{l}\mathrm{k}=3 \\
N=1,173 \\
\mathrm{RBAR}=.76 \\
\mathrm{SD}=.1466 \\
\rho=.97 \\
\mathrm{SD} \rho=.1731 \\
\end{array}$ \\
\hline
\end{tabular}

Note. Please see other tables for descriptions of symbols used. 
TABLE 21

Meta-Analytic Results: Organizational Commitment with Work Ethic Endorsement Variables

\begin{tabular}{|c|c|c|c|c|c|c|}
\hline & OC & $\begin{array}{l}\text { Attitudinal } \\
\text { OC }\end{array}$ & $\begin{array}{l}\text { Calculative } \\
\text { OC }\end{array}$ & $\begin{array}{l}\text { Affective } \\
\text { OC }\end{array}$ & $\begin{array}{l}\text { Continuance } \\
\text { OC }\end{array}$ & $\begin{array}{l}\text { Normative } \\
\text { OC }\end{array}$ \\
\hline $\begin{array}{l}\text { WE } \\
\text { Endorse- } \\
\text { ment }\end{array}$ & \begin{tabular}{l|}
$\mathrm{k}=4$ \\
$\mathrm{~N}=3,586$ \\
$\mathrm{RBAR}=.33$ \\
$\mathrm{SDr}=.0658$ \\
$\rho=.42$ \\
$\mathrm{SD} \rho=.0670$ \\
\end{tabular} & I & $I$ & $\begin{array}{l}\mathrm{k}=3 \\
\mathrm{~N}=1,016 \\
\mathrm{RBAR}=.27 \\
\mathrm{SDr}=.0420 \\
\rho=.34 \\
\mathrm{SD} \rho=0\end{array}$ & I & $\mathrm{I}$ \\
\hline $\begin{array}{l}\text { Protestant } \\
\text { WE } \\
\text { Endorse- } \\
\text { ment }\end{array}$ & $\begin{array}{l}\mathrm{k}=13 \\
\mathrm{~N}=3,093 \\
\mathrm{RBAR}=.27 \\
\mathrm{SDr}=.1099 \\
\rho=.35 \\
\mathrm{SD} \rho=.1125\end{array}$ & I & $\begin{array}{l}\mathrm{k}=3 \\
\mathrm{~N}=353 \\
\mathrm{RBAR}=.03 \\
\mathrm{SDr}=.0384 \\
\rho=.04 \\
\mathrm{SD} \rho=0\end{array}$ & $\begin{array}{l}\mathrm{k}=4 \\
\mathrm{~N}=940 \\
\mathrm{RBAR}=.08 \\
\mathrm{SDr}=.0176 \\
\rho=.11 \\
\mathrm{SD} \rho=0\end{array}$ & $\begin{array}{l}\mathrm{k}=3 \\
\mathrm{~N}=591 \\
\mathrm{RBAR}=.09 \\
\mathrm{SDr}=.0623 \\
\rho=.13 \\
\mathrm{SD} \rho=0\end{array}$ & $\begin{array}{l}k=2 \\
N=369 \\
R B A R=.14 \\
S D r=.0383 \\
\rho=.20 \\
S D \rho=0\end{array}$ \\
\hline$\overline{W E}$ & $\begin{array}{l}k=3 \\
N=969 \\
R B A R=.30 \\
S D r=.0736 \\
\rho=.38 \\
S D \rho=.0617\end{array}$ & I & $I$ & I & I & I \\
\hline $\begin{array}{l}\text { Work } \\
\text { Involve- } \\
\text { ment }\end{array}$ & $\begin{array}{l}\mathrm{k}=16 \\
N=5,458 \\
\mathrm{RBAR}=.34 \\
\mathrm{SDr}=.0832 \\
\rho=.42 \\
\mathrm{SD} \rho=.0774\end{array}$ & I & I & $\begin{array}{l}k=1 \\
N=238 \\
R B A R=.41 \\
S D r=- \\
p=.51 \\
S D \rho^{-}=\end{array}$ & $\begin{array}{l}\mathrm{k}=1 \\
\mathrm{~N}=238 \\
\mathrm{RBAR}=.05 \\
\mathrm{SDr}=- \\
\rho=.07 \\
\mathrm{SD} \rho=-\end{array}$ & $\begin{array}{l}k=1 \\
N=238 \\
R B A R=33 \\
S D r=- \\
\rho=44 \\
S D \rho=-\end{array}$ \\
\hline
\end{tabular}

Note. $O C$, organizational commitment; $W E$, work ethic; $K$, number of correlations included in the analysis; $N$, total sample size; $R B A R$, sample size weighted mean observed correlation; $S D r$, sample size weighted standard deviation of mean observed correlation; $\rho, \operatorname{RBAR}$ corrected for unreliability; $S D \rho$, standard deviation of $\rho ; 1$, incomplete cell. 
TABLE 22

Meta-Analytic Results: Organizational Commitment and Union Commitment Variables

\begin{tabular}{|c|c|c|c|c|c|c|}
\hline & $\overline{O C}$ & $\begin{array}{l}\text { Attitudinal } \\
\text { OC }\end{array}$ & $\begin{array}{l}\text { Calculative } \\
\text { OC }\end{array}$ & $\begin{array}{l}\text { Affective } \\
\text { OC }\end{array}$ & $\begin{array}{l}\text { Contin- } \\
\text { uance } O C\end{array}$ & $\begin{array}{l}\text { Normative } \\
\text { OC }\end{array}$ \\
\hline $\begin{array}{l}\text { Union } \\
\text { Commitment }\end{array}$ & $\begin{array}{l}\mathrm{k}=21 \\
\mathrm{~N}=5,093 \\
\mathrm{RBAR}=.12 \\
\mathrm{SDr}=.2234 \\
\rho=.14 \\
\mathrm{SD} \rho=.2469\end{array}$ & $I$ & $I$ & $\begin{array}{l}\mathrm{k}=2 \\
\mathrm{~N}=542 \\
\mathrm{RBAR}=.28 \\
\mathrm{SDr}=.0150 \\
\rho=.33 \\
\mathrm{SD} \rho=0\end{array}$ & I & $\begin{array}{l}\mathrm{k}=1 \\
\mathrm{~N}=176 \\
\mathrm{RBAR}=-.18 \\
\mathrm{SDr}=- \\
\rho=-.22 \\
\mathrm{SD} \rho=-\end{array}$ \\
\hline Loyalty & $\begin{array}{l}k=18 \\
N=8,881 \\
R B A R=.15 \\
S D r=.1305 \\
\rho=.18 \\
S D \rho=.1405\end{array}$ & I & $\mathrm{I}$ & $\begin{array}{l}\mathrm{k}=3 \\
\mathrm{~N}=2,466 \\
\mathrm{RBAR}=.21 \\
\mathrm{SDr}=.0418 \\
\rho=.24 \\
\mathrm{SD} \rho=.0271\end{array}$ & $\begin{array}{l}k=1 \\
N=48 \\
R B A R=-.13 \\
S D r=- \\
\rho=-.16 \\
S D \rho=-\end{array}$ & $\mathrm{I}$ \\
\hline Responsibility & $\begin{array}{l}\mathrm{k}=9 \\
\mathrm{~N}=11,670 \\
\mathrm{RBAR}=-.03 \\
\mathrm{SDr}=.0381 \\
\rho=-.04 \\
\mathrm{SD} \rho=.0352\end{array}$ & I & I & $\begin{array}{l}\mathrm{k}=2 \\
\mathrm{~N}=2,337 \\
\mathrm{RBAR}=-.11 \\
\mathrm{SDr}=.0255 \\
\rho=-.14 \\
\mathrm{SD} \rho=0\end{array}$ & $\begin{array}{l}k=1 \\
N=48 \\
\text { RBAR=-.04 } \\
\text { SDr=- } \\
\rho=-.05 \\
\text { SD } \rho=-\end{array}$ & I \\
\hline Willingness & $\begin{array}{l}\mathrm{k}=7 \\
\mathrm{~N}=1,278 \\
\mathrm{RBAR}=.06 \\
\mathrm{SDr}=.0949 \\
\rho=.07 \\
\mathrm{SD} \rho=.0728\end{array}$ & I & I & $\begin{array}{l}k=2 \\
N=177 \\
R B A R=.26 \\
S D r=.0758 \\
\rho=.32 \\
S D \rho=0 \\
\end{array}$ & $\begin{array}{l}\mathrm{k}=1 \\
\mathrm{~N}=48 \\
\mathrm{RBAR}=-.13 \\
\mathrm{SDr}=- \\
\rho=-.17 \\
\mathrm{SD} \rho^{=-}\end{array}$ & I \\
\hline $\begin{array}{l}\text { Belief in } \\
\text { Unionism }\end{array}$ & $\begin{array}{l}\mathrm{k}=7 \\
N=1,210 \\
\mathrm{RBAR}=-.10 \\
\mathrm{SDr}=.0435 \\
\rho=-.12 \\
\mathrm{SD} \rho=0\end{array}$ & II & $\mathrm{I}$ & I & I & I \\
\hline
\end{tabular}

Note. $O C$, organizational commitment; $K$, number of correlations included in the analysis; $N$, total sample size; $R B A R$, sample size weighted mean observed correlation; $S D r$, sample size weighted standard deviation of mean observed correlation; $\rho$, RBAR corrected for unreliability; $S D \rho$, standard deviation of $\rho ; I$, incomplete cell. 
TABLE 23

Meta-Analytic Results: Job Involvement, CPO, and Work Ethic Endorsement

\begin{tabular}{|c|c|c|c|c|}
\hline & WE Endorsement & $\begin{array}{l}\text { Protestant WE } \\
\text { Endorsement }\end{array}$ & WE & $\begin{array}{l}\text { Work } \\
\text { Involvement }\end{array}$ \\
\hline $\begin{array}{l}\text { Job } \\
\text { Involvement }\end{array}$ & $\begin{array}{l}k=7 \\
N=4,602 \\
R B A R=.37 \\
S D r=.0619 \\
\rho=.49 \\
S D \rho=.0548\end{array}$ & $\begin{array}{l}k=31 \\
N=7,663 \\
\operatorname{RBAR}=.30 \\
S D r=.1061 \\
\rho=.42 \\
S D \rho=.1104\end{array}$ & $\begin{array}{l}k=6 \\
N=1,385 \\
R B A R=.23 \\
S D r=.1532 \\
\rho=.30 \\
S D \rho=.1807\end{array}$ & $\begin{array}{l}\mathrm{k}=40 \\
\mathrm{~N}=22,085 \\
\mathrm{RBAR}=.20 \\
\mathrm{SDr}=.3093 \\
\rho=.26 \\
\mathrm{SD} \rho=.3916\end{array}$ \\
\hline $\mathbf{C P O}$ & $\begin{array}{l}\mathrm{k}=3 \\
N=1,165 \\
\operatorname{RBAR}=.28 \\
\mathrm{SDr}=.0545 \\
\rho=.36 \\
\mathrm{SD} \rho=.0165\end{array}$ & $\begin{array}{l}k=5 \\
N=1,037 \\
R B A R=.18 \\
S D r=.0634 \\
\rho=.25 \\
S D \rho=0\end{array}$ & $\begin{array}{l}k=1 \\
N=389 \\
R B A R=.10 \\
S D r=- \\
\rho=.13 \\
S D \rho=-\end{array}$ & $\begin{array}{l}k=6 \\
N=1,998 \\
\mathrm{RBAR}=.32 \\
\mathrm{SDr}=.0847 \\
\rho=.40 \\
\mathrm{SD} \rho=.0792\end{array}$ \\
\hline Career Salience & $\begin{array}{l}k=1 \\
N=563 \\
R B A R=.46 \\
S D r=- \\
\rho=.65 \\
S D \rho=-\end{array}$ & $\begin{array}{l}k=3 \\
N=1,467 \\
R B A R=.36 \\
S D r=.1158 \\
\rho=.51 \\
S D \rho=.1413\end{array}$ & I & 1 \\
\hline $\begin{array}{l}\text { Career } \\
\text { Involvement }\end{array}$ & $\begin{array}{l}k=1 \\
N=498 \\
R B A R=.21 \\
S D r=- \\
\rho=.29 \\
S D p=-\end{array}$ & $I$ & $\mathrm{I}$ & $\bar{I}$ \\
\hline Professionalism & $I$ & $\mathrm{I}$ & I & I \\
\hline Affective Occ. & I & $\mathrm{I}$ & I & I \\
\hline $\begin{array}{l}\text { Continuance } \\
\text { Occ. }\end{array}$ & $\bar{I}$ & $\mathrm{I}$ & I & I \\
\hline Normative Occ. & $\bar{I}$ & $I$ & I & I \\
\hline
\end{tabular}

Note. $C P O$, career/professional/occupational commitment; Occ., occupational commitment; $W E$, work ethic; $K$, number of correlations included in the analysis; $N$, total sample size; $R B A R$, sample size weighted mean observed correlation; $S D r$, sample size weighted standard deviation of mean observed correlation; $\rho$, RBAR corrected for unreliability; $S D \rho$, standard deviation of $\rho$; $I$, incomplete cell. 


\section{TABLE 24}

Meta-Analytic Results: Job Involvement, CPO, and Union Commitment Variables

\begin{tabular}{|c|c|c|c|c|c|}
\hline & $\begin{array}{l}\text { Union } \\
\text { Commit- } \\
\text { ment }\end{array}$ & Loyalty & Responsibility & Willingness & $\begin{array}{l}\text { Belief in } \\
\text { Unionism }\end{array}$ \\
\hline $\begin{array}{l}\text { Job } \\
\text { Involvement }\end{array}$ & $\begin{array}{l}k=2 \\
N=306 \\
R B A R=-.15 \\
S D r=.5853 \\
\rho=-.19 \\
S D \rho=.6989\end{array}$ & $\begin{array}{l}k=4 \\
N=2,016 \\
R B A R=.06 \\
S D r=.0621 \\
\rho=.08 \\
S D \rho=.0519\end{array}$ & I & $\begin{array}{l}\mathrm{k}=1 \\
N=297 \\
\mathrm{RBAR}=.07 \\
\mathrm{SDr}=- \\
\rho=.09 \\
\mathrm{SD} \rho=-\end{array}$ & $\begin{array}{l}\mathrm{k}=2 \\
\mathrm{~N}=406 \\
\mathrm{RBAR}=.04 \\
\mathrm{SD}=.0798 \\
\rho=.05 \\
\mathrm{SD} \rho=.0476 \\
\end{array}$ \\
\hline CPO & $\begin{array}{l}\mathrm{k}=3 \\
\mathrm{~N}=378 \\
\mathrm{RBAR}=.47 \\
\mathrm{SDr}=.1559 \\
\rho=.56 \\
\mathrm{SD} \rho=.1597\end{array}$ & $\mathrm{I}$ & $I$ & $\mathrm{I}$ & 1 \\
\hline Career Salience & $\mathrm{I}$ & I & $\mathrm{T}$ & I & 1 \\
\hline $\begin{array}{l}\text { Career } \\
\text { Involvement }\end{array}$ & I & $\mathrm{I}$ & $I$ & I & I \\
\hline Professionalism & I & I & $\mathrm{I}$ & 1 & I \\
\hline Affective Occ. & $I$ & $\begin{array}{l}k=2 \\
N=258 \\
R B A R=.30 \\
S D r=.0800 \\
\rho=.35 \\
S D \rho=0 \\
\end{array}$ & $I$ & $\begin{array}{l}\mathrm{k}=2 \\
\mathrm{~N}=258 \\
\mathrm{RBAR}=.31 \\
\mathrm{SDr}=.0100 \\
\rho=.38 \\
\mathrm{SD} \rho=0 \\
\end{array}$ & I \\
\hline $\begin{array}{l}\text { Continuance } \\
\text { Occ. }\end{array}$ & I & I & I & 1 & I \\
\hline Normative Occ. & I & I & I & I & 1 \\
\hline
\end{tabular}

Note. $C P O$, career/professional/occupational commitment; $O c c$., occupational commitment; $K$, number of correlations included in the analysis; $N$, total sample size; $R B A R$, sample size weighted mean observed correlation; $S D r$, sample size weighted standard deviation of mean observed correlation; $\rho$, RBAR corrected for unreliability; $S D \rho$, standard deviation of $\rho ; l$, incomplete cell. 
TABLE 25

Meta-Analytic Results: Work Ethic Endorsement and Union Commitment Variables

\begin{tabular}{|c|c|c|c|c|}
\hline & $\begin{array}{l}\text { WE } \\
\text { Endorsement }\end{array}$ & $\begin{array}{l}\text { Protestant WE } \\
\text { Endorsement }\end{array}$ & WE & $\begin{array}{l}\text { Work } \\
\text { Involvement }\end{array}$ \\
\hline Union Commitment & $\mathrm{I}$ & I & $\mathrm{I}$ & I \\
\hline Loyalty & $\mathrm{I}$ & $\mathrm{I}$ & $I$ & $\mathrm{I}$ \\
\hline Responsibility & 1 & $\mathrm{I}$ & $I$ & I \\
\hline Willingness & $I$ & I & $I$ & I \\
\hline Belief in Unionism & I & I & I & I \\
\hline
\end{tabular}

Note. WE, work ethic; $I$, incomplete cell. 


\section{LIST OF REFERENCES}

Aiken, L., \& West, S. G. (1993). Detecting interactions in multiple regression: Measurement error, power, and design considerations. The Score, APA Division 5 Newsletter, 16, 7.

Allen, N. J., \& Meyer, J. P. (1990). The measurement and antecedents of affective, continuance and normative commitment to the organization. Journal of Occupational Psychology, 63, 1-18.

Allen, T. D., \& Russell, J. E. (1999). Parental leave of absence: Some not so family-friendly implications. Journal of Applied Social Psychology, 29, 166-191.

Alutto, J. A., Hrebiniak, L. G., \& Alonso, R. C. (1973). On operationalizing the concept of commitment. Social Forces, 51, 448-454.

Andrews, F. M., \& Withey, S. B. (1976). Social Indicators of Well-Being. New York: Plenum.

Andrisani, P. J., \& Nestel, G. (1976). Internal-external control as a contributor to and outcome of work experience. Journal of Applied Psychology, 61, 156-165.

Aranya, N., Pollack, J., \& Amernic, J. (1981). An examination of professional commitment in public accounting. Accounting, Organizations and Society, 6, 271-280.

Baack, D., Luthans, F., \& Rogers, J. (1993). Analysis of the organizational commitment of clergy members. Journal of Managerial Issues, 5, 232-253.

Becker, B., \& Gerhart, B. (1996). The impact of human resource management on organizational performance: Progress and prospects. Academy of Management Journal. 39, 779-801.

Becker, H. S. (1960). Notes on the concept of commitment. American Journal of Sociology, 66, 32-42.

Becker, T. E. (1992). Foci and bases of commitment: Are they distinctions worth making? Academy of Management Journal, 35, 232-244.

Becker, T. E., Billings, R. S., Eveleth, D. M., \& Gilbert, N. C. (1996). Foci and bases of employee commitment: Implications for job performance. Academy of Management Journal, 39, 464-482.

Beehr, T. A. (1996). Basic organizational psychology. Boston: Allyn \& Bacon. 
Behrman, D. N., \& Perreault, W. D., Jr. (1982). Measuring the performance of industrial salespersons. Journal of Business Research, 10, 355-370.

Ben-Sira, Z. (1986). The plight of primary medical care: The problematics of 'committedness' to the practice. Social Science and Medicine, 22, 699-712.

Bernardin, H. J., \& Beatty, R. W. (1984). Performance appraisal: Assessing human behavior at work. Boston: PWS.

Blau, G. J. (1985). A multiple study investigation of the dimensionality of job involvement. Journal of Vocational Behavior, 27, 19-36.

Blau, G. J. (1988). Further exploring the meaning and measurement of career commitment. Journal of Vocational Behavior, 32, 284-297.

Blood, M. R. (1969). Work values and job satisfaction. Journal of Applied Psychology, 53, 456-459.

Bluedorn, A. C. (1982). A unified model of turnover from organizations. Human Relations, 35, 135-153.

Brayfield, A. H., \& Rothe, H. F. (1951). An index of job satisfaction. Journal of Applied Psychology, 35, 307-311.

Brierley, J. A. (1998). Accountants' organizational-professional conflict: A metaanalysis. The Journal of Psychology, 132, 291-300.

Brown, S. P. (1996). A meta-analysis and review of organizational research on job involvement. Psychological Bulletin, 120, 235-255. 1188.

Buchholz, R. A. (1976). Measurement of beliefs. Human Relations, 29, 1177-

Buchholz, R. A. (1977). The belief structure of managers relative to work concepts measured by a factor analytic model. Personnel Psychology, 30, 567-587.

Cammann, C., Fichman, M., Jenkins, D., \& Klesh, J. (1979). The Michigan Organizational Assessment Questionnaire. Unpublished manuscript, University of Michigan, Ann Arbor.

Cammann, C., Fichman, M., Jenkins, G. D., Jr., \& Klesh, J. R. (1983). Assessing the attitudes and perceptions of organizational members. In S.E. Seashore, E. E. Lawler, P. H. Mirvis, and C. Cammann (Eds.), Assessing organizational change: A guide to methods, measures, and practices (pp. 71-138). New York: Wiley. 
Campbell, J. P., McCloy, R. A., Oppler, S. H., \& Sager, C. E. (1993). A theory of performance. In N. Schmitt \& W. C. Borman (Eds.), Personnel selection in organizations (pp. 35-70). San Francisco: Josey-Bass.

Churchill, G. A., Ford, N. M., \& Walker, O. C. (1974). Measuring the job satisfaction of industrial salesmen. Journal of Marketing Research, 11, 254-260.

Cohen, A. (1991). Career stage as a moderator of the relationships between organizational commitment and its outcomes: A meta-analysis. Journal of Occupational Psychology, 64, 253-268.

Cohen, A. (1992). Antecedents of organizational commitment across occupational groups: A meta-analysis. Journal of Organizational Behavior, 13, 539-558.

Cohen, A. (1993a). Age and tenure in relation to organizational commitment: A meta-analysis. Basic and Applied Social Psychology, 14, 143-159.

Cohen, A. (1993b). Organizational commitment and turnover: A meta-analysis. Academy of Management Journal, 36, 1140-1157.

Cohen, A., \& Gattiker, U. E. (1994). Rewards and organizational commitment across structural characteristics: A meta-analysis. Journal of Business and Psychology, 9, 137-157.

Cohen, A., \& Hudecek, N. (1993). Organizational commitment-turnover relationships across occupational groups: A meta-analysis. Group and Organization Management, 18, 188-213.

Cohen, J. (1988). Statistical power analysis ( $\left.2^{\text {nd }} \mathrm{ed}.\right)$. Hillsdale: Erlbaum.

Colarelli, S. M. (1984). Methods of communication and mediating processes in realistic job previews. Journal of Applied Psychology, 69, 633-642.

Colarelli, S. M., \& Bishop, R. C. (1990). Career commitment: Functions, correlates, and management. Group and Organizational Studies, 15, 158-176.

Cook, J. D., Hepworth, S. J., Wall, T. D., \& Warr, P. B. (1981). The experience of work. New York: Academic Press.

Cook, J. D., \& Wall, T. D. (1980). New work attitude measures of trust, organizational commitment and personal need non-fulfillment. Journal of Occupational Psychology, 53, 39-52. 
Dailey, R. C., \& Morgan, C. P. (1978). Personal characteristics and job involvement as antecedents of boundary spanning behaviour: A path analysis. The Journal of Management Studies, 15, 330-339.

Damanpour, F. (1991). Organizational innovation: A meta-analysis of effects of determinants and moderators. Academy of Management Journal, 34, 555-590.

DeCotiis, T. A., \& Summers, T. P. (1987). A path analysis of a model of antecedents and consequences of organizational commitment. Human Relations, 40, 445470 .

Dickson, J. W., \& Buchholz, R. A. (1979). Differences in beliefs about work between managers and blue-collar workers. Journal of Management Studies, 16, 235-251.

Drasgow, F., \& Miller, H. E. (1982). Psychometric and substantive issues in scale construction and validation. Journal of Applied Psychology, 67, 268-279.

Dubin, R. (1956). Industrial workers' worlds: A study of the 'central life interests' of industrial workers. Social Problems, $3,131-142$.

Dunham, R. B., Smith, F. J., \& Blackburn, R. S. (1977). Validation of the Index of Organizational Reactions with the JDI, the MSQ, and Faces Scales. Academy of Management Journal, 20, 420-432.

Eby, L. T., Freeman, D. M., Rush, M. C., \& Lance, C. E. (1999). Motivational bases of affective organizational commitment: A partial test of an integrative theoretical model. Journal of Occupational and Organizational Psychology, 72, 463-483.

Elfering, A., Semmer, N. K., \& Kalin, W. (2000). Stability and change in job satisfaction at the transition from vocational training into "real work." Swiss Journal of Psychology, 59, 256-271.

Farrell, D., \& Rusbult, C. E. (1981). Exchange variables as predictors of job satisfaction, job commitment, and turnover: The mpact of rewards, costs, alternatives, and investments. Organizational Behavior and Human Performance, 27, 78-95.

Fullager, C. (1986). A factor analytic study on the validity of a union commitment scale. Journal of Applied Psychology, 71, 129-136.

Furnham, A. (1990). A content, correlational, and factor analytic study of seven questionnaire measures of the Protestant Work Ethic. Human Relations, 43, 383-399.

Furnham, A. (1997). The relationship between work and economic values. Journal of Economic Psychology, 18, 1-14. 
Ganster, D. C., Fusilier, M. R., \& Mayes, B. T. (1986). Role of social support in the experience of stress at work. Journal of Applied Psychology, 71, 102-110.

Gordon, M. E., Philpot, J. W., Burt, R. E., Thompson, C. A., \& Spiller, W. E. (1980). Commitment to the union: Development of a measure and an examination of its correlates. Journal of Applied Psychology, 65, 479-499.

Gould, S. (1979). Characteristics of career planners in upwardly mobile occupations. Academy of Management Journal, 22, 539-550.

Gouldner, A. W. (1958). Cosmopolitans and locals: Toward an analysis of latent social identity. Administrative Science Quarterly, 3, 444-480.

Greenhaus, J. H. (1971). An investigation of the role of career salience in vocational behavior. Journal of Vocational Behavior, 1, 209-216.

Greenhaus, J. H., Parasuraman, S., \& Wormley, W. M. (1990). Effects of race on organizational experiences, job performance evaluations, and career outcomes. Academy of Management Journal, 33, 64-86.

Grover, S. L. (1993). Why professionals lie: The impact of professional role conflict on reporting accuracy. Organizational Behavior and Human Decision Processes, $\underline{55}, 251-272$.

Grube, J. A., \& Piliavin, J. A. (2000). Role identity, organizational experiences, and volunteer performance. Personality and Social Psychology Bulletin, 26, 1108-1119.

Guimond, S. (1995). Encounter and metamorphosis: The impact of military socialisation on professional values. Applied Psychology: An International Review, 44. 251-275.

Hackett, R. D. (1989). Work attitudes and employee absenteeism: A synthesis of the literature. Journal of Occupational Psychology, 62, 235-248.

Hackman, J. R., \& Lawler, E. E. (1971). Employee reactions to job characteristics. Journal of Applied Psychology, 55, 259-286.

Hackman, J. R., \& Oldham, G. R. (1975). Development of the Job Diagnostic Survey. Journal of Applied Psychology, 60, 159-170.

Hackman, J. R., \& Oldham, G. R. (1980). Work redesign. Reading, MA: Addison-Wesley. 
Hall, D. T., \& Lawler, E. E. (1970). Job characteristics and pressures and the organizational integration of professionals. Administrative Science Quarterly, 15, 271281.

Hall, R. H. (1968). Professionalization and bureaucratization. American Sociological Review, 33, 92-104.

Hanisch, K. A., \& Hulin, C. L. (1990). Job attitudes and organizational withdrawal: An examination of retirement and other voluntary withdrawal behaviors. Journal of Vocational Behavior, 37, 60-78.

Hanisch, K. A., \& Hulin, C. L. (1991). General attitudes and organizational withdrawal: An evaluation of a causal model. Journal of Vocational Behavior, 39, 110128.

Hatfield, J. D., Robinson, R. B., \& Huseman, R. C. (1985). An empirical evaluation of a test for assessing job satisfaction. Psychological Reports, 56, 39-45.

Heneman, H. G., \& Schwab, D. P. (1985). Pay satisfaction: Its multidimensional nature and measurement. International Journal of Psychology, 20, 129-141.

Higgins, C. A., Duxbury, L. E., \& Irving, R. H. (1992). Work-family conflict in the dual-career family. Organizational Behavior and Human Decision Processes, 51, 5175 .

Hrebiniak, L. G., \& Alutto, J. A. (1972). Personal and role-related factors in the development of organizational commitment. Administrative Science Quarterly, 17, 555573.

Iaffaldano, M. T., \& Muchinsky, P. M. (1985). Job satisfaction and job performance: A meta-analysis. Psychological Bulletin, 97, 251-273.

Indiresan, J. (1975). Multivariate analysis of factors affecting the job satisfaction of engineering teachers. Indian Journal of Psychometry and Education. 6, 16-27.

Ironson, G. H., Smith, P. C., Brannick, M. T., \& Gibson, W. M. (1989). Construction of a Job in General Scale: A comparison of global, composite, and specific measures. Journal of Applied Psychology, 74, 193-200.

Irving, P. G., Coleman, D. F., \& Cooper, C. L. (1997). Further assessments of a three component model of occupational commitment: Generalizability and differences across occupations. Journal of Applied Psychology, 82, 444-452. 
Jackson, P. R., Stafford, E.M., Banks, M.H., \& Warr, P.B. (1983). Unemployment and psychological distress in young people: The moderating role of employment commitment. Journal of Applied Psychology, 68, 525-535.

Johnson, W. R., Johnson, G. J., \& Patterson, C. R. (1999). Moderators of the relationship between company and union commitment: A meta-analysis. The Journal of Psychology, 133, 85-103.

Jorde-Bloom, P. (1985). The Early Childhood Job Satisfaction Survey. Unpublished manuscript, National College of Education, Evanston.

Kahn, W. A. (1990). Psychological conditions of personal engagement and disengagement at work. Academy of Management Journal, 33, 692-724.

Kanungo, R. N. (1979). The concepts of alienation and involvement revisited. Psychological Bulletin, 86, 119-138.

Kanungo, R. N. (1982). Measurement of job and work involvement. Journal of Applied Psychology, 67, 341-349.

Kanungo, R. N., Gorn, G. J., \& Dauderis, H. J. (1976). Motivational orientation of Canadian Anglophone and Francophone managers. Canadian Journal of Behavioural Science, $8,107-121$.

Kanungo, R. N., Misra, S. B., \& Dayal, I. (1975). Relationship of job involvement to perceived importance and satisfaction of employee needs. International Review of Applied Psychology, 24, 49-59.

Kim, S. W., Price, J. L., Mueller, C. W., \& Watson, T. W. (1996). The determinants of career intent among physicians at a U. S. Air Force hospital. Human Relations, 49, 947-976.

Kim, W. C., \& Mauborgne, R. A. (1993). Procedural justice, attitudes, and subsidiary top management compliance with multinationals' corporate strategic decisions. Academy of Management Journal, 36, 502-526.

Ko, J., Price, J. L., \& Mueller, C. W. (1997). Assessment of Meyer and Allen's three-component model of organizational commitment in South Korea. Journal of Applied Psychology, 82, 961-973.

Kreitner, R., \& Kinicki, A. (1998). Organizational behavior. ( $3^{\text {rd }}$ ed.). Boston: McGraw-Hill. 
Kunin, T. (1955). The construction of a new type of attitude measure. Personnel Psychology, 8, 65-77.

Lam, P., Foong, Y. Y., \& Moo, S. N. (1995). Work life, career commitment, and job satisfaction as antecedents of career withdrawal cognition among teacher interns. Journal of Research and Development in Education, 28, 230-236.

Landau, J., \& Hammer, T. H. (1986). Clerical employees' perceptions of intraorganizational career opportunities. Academy of Management Journal, 29, 385-404.

Larwood, L., Wright, T. A., Desrochers, S., \& Dahir, V. (1998). Extending latent role and psychological contract theories to predict intent to turnover and politics in business organizations. Group and Organization Management, 23, 100-123.

Lawler, E. E., \& Hall, D. T. (1970). Relationships of job characteristics to job involvement, satisfaction, and intrinsic motivation. Journal of Applied Psychology, 54, 305-312.

Lee, K., Carswell, J. J., \& Allen, N. J. (2000). A meta-analytic review of occupational commitment: Relations with person- and work-related variables. Journal of Applied Psychology, 85, 799-811.

Levenson, H. (1973). Multidimensional locus of control in psychiatric patients. Journal of Consulting and Clinical Psychology, 41, 397-404.

Lodahl, T. M., \& Kejner, M. (1965). The definition and measurement of job involvement. Journal of Applied Psychology, 49, 24-33.

London, M., Cheney, L. A., \& Tavis, R. L., (1977). The relationship between cosmopolitan-local orientation and job performance. Journal of Vocational Behavior, 11 , 182-195.

Lyons, T. F. (1971). Role clarity, need for clarity, satisfaction, tension, and withdrawal. Organizational Behavior and Human Decision Processes, 6, 99-110.

Mael, F. (1988). Organizational identification: Construct redefinition and a field application with organizational alumni. Unpublished doctoral dissertation, Wayne State University, Detroit.

Mael, F., \& Ashforth, B. E. (1992). Alumni and their alma mater: A partial test of the reformulated model of organizational identification. Journal of Organizational Behavior, 13, 103-123.

March, J. G., \& Simon, H. A. (1958). Organizations. New York: Wiley. 
Mathieu, J. E. (1988). A causal model of organizational commitment in a military training environment. Journal of Vocational Behavior, 32, 321-335.

Mathieu, J. E., \& Zajac, D. M. (1990). A review and meta-analysis of the antecedents, correlates, and consequences of organizational commitment. Psychological Bulletin, 108, 171-194.

McKelvey, B., \& Sekaran, U. (1977). Toward a career-based theory of job involvement: A study of scientists and engineers. Administrative Science Quarterly, 22, 281-305.

McNichols, C. W., Stahl, M. J., \& Manley, T. R. (1978). A validation of Hoppock's job satisfaction measure. Academy of Management Journal, 21, 737-742.

Mellor, S. (1990). The relationship between membership decline and union commitment: A field study of local unions in crisis. Journal of Applied Psychology, 75, 258-267.

Meyer, J. P., \& Allen, N. J. (1984). Testing the "side-bet theory" of organizational commitment: Some methodological considerations. Journal of Applied Psychology, 69, 372-378.

Meyer, J. P., \& Allen, N. J. (1991). A three-component conceptualization of organizational commitment. Human Resource Management Review, 1, 61-89.

Meyer, J. P., Allen, N. J., \& Gellatly, I. R. (1990). Affective and continuance commitment to the organization: Evaluation of measures and analysis of concurrent and time-lagged relations. Journal of Applied Psychology, 75, 710-720.

Meyer, J. P., Allen, N. J., \& Smith, K. A. (1993). Commitment to organizations and occupations: Extension and test of a three-component conceptualization. Journal of Applied Psychology, 78, 538-551.

Mirels, H. L., \& Garrett, J. B. (1971). The Protestant ethic as a personality variable. Journal of Consulting and Clinical Psychology, 36, 40-44.

Mobley, W. H. (1977). Intermediate linkages in the relationship between job satisfaction and employee turnover. Journal of Applied Psychology, 62, 237-240.

Mobley, W. H., Griffeth, R. W., Hand, H. H., \& Meglino, B. M. (1979). Review and conceptual analysis of the employee turnover process. Psychological Bulletin, 86, 493-522.

Mobley, W. H., Horner, S. O., \& Hollingsworth, A. T. (1978). An evaluation of precursors of hospital employee turnover. Journal of Applied Psychology, 63, 408-414. 
Morrow, P.C. (1983). Concept redundancy in organizational research: The case of work commitment. Academy of Management Review, 8, 486-500.

Morrow, P.C. (1993). The theory and measurement of work commitment. Greenwich: JAI Press Inc.

Morrow, P.C., \& Goetz, J.F., Jr. (1988). Professionalism as a form of work commitment. Journal of Vocational Behavior, 32, 92-111.

Morrow, P. C., \& McElroy, J. C. (1986). On assessing measures of work commitment. Journal of Occupational Behaviour, 7, 139-145.

Morrow, P.C., \& McElroy, J.C. (1987). Work commitment and job satisfaction over three career stages. Journal of Vocational Behavior, 30, 330-346.

Morrow, P. C., \& Wirth, R. E. (1989). Work commitment among salaried professionals. Journal of Vocational Behavior, 34, 40-56.

Mowday, R. T., Porter, L. M., \& Steers, R. M. (1982). Employee-organization linkages. New York: Academic Press.

Mowday, R. T., Steers, R. M., \& Porter, L. M. (1979). The measurement of organizational commitment. Journal of Vocational Behavior, 14, 224-247.

Nunnally, J. C., \& Bernstein, I. H. (1994). Psychometric theory. ( $3^{\text {rd }}$ ed.). New York: McGraw-Hill, Inc.

O'Reilly, C. A., \& Chatman, J. (1986). Organizational commitment and psychological attachment: The effects of compliance, identification, and internalization on prosocial behavior. Journal of Applied Psychology, 71, 492-499.

Patchen, M. (1970). Participation, achievement, and involvement on the job. Englewood Cliffs, N.J.: Prentice-Hall.

Pestonjee, D. M. (1973). Organizational structures and job attitudes. Calcutta: The Minerva Associates.

Porter, L. W., Crampon, W. J., \& Smith, F. J. (1976). Organizational commitment and managerial turnover: A longitudinal study. Organizational Behavior and Human Decision Processes, 15, 87-98.

Porter, L. W., \& Smith, F. J. (1970). The etiology of organizational commitment. Unpublished manuscript, University of California, Irvine. 
Porter, L.W., Steers, R. M., Mowday, R. T., \& Boulian, P.V. (1974). Organizational commitment, job satisfaction, and turnover among psychiatric technicians. Journal of Applied Psychology, 59, 603-609.

Putti, J. M., Aryee, S., \& Liang, T. K. (1989). Work values and organizational commitment: A study in the Asian context. Human Relations, 42, 275-288.

Quinn, R. P., \& Shepard, L. J. (1974). The 1972-73 Quality of Employment Survey: Descriptive statistics, with comparison data from the 1969-70 Survey of Working Conditions. Ann Arbor: Institute for Social Research, University of Michigan.

Quinn, R. P., \& Staines, G. L. (1979). The 1977 Quality of Employment Survey. Ann Arbor: Institute for Social Research, University of Michigan.

Randall, D. M. (1990). The consequences of organizational commitment: methodological investigation. Journal of Organizational Behavior, 11, 361-378.

Randall, D. M. (1993). Cross-cultural research on organizational commitment: A review and application of Hofstede's Value Survey Module. Journal of Business Research, 26, 91-110.

Regoli, R. M., \& Poole, E. D. (1980). Police professionalism and role conflict: A comparison of rural and urban departments. Human Relations, 33, 241-252.

Riggio, R.E. (1999). Introduction to Industrial/Organizational Psychology $\left(3^{\text {rd }}\right.$ ed). Upper Saddle River: Prentice Hall.

Rotter, J. B. (1966). Generalized expectancies for internal versus external control of reinforcement. Psychological Monographs, 80, 609.

Rotter, J. B., \& Mulray, R. C. (1965). Internal versus external control of reinforcement and decision time. Journal of Personality and Social Psychology, 2, 598604.

Roznowski, M. (1989). Examination of the measurement properties of the Job Descriptive Index with experimental items. Journal of Applied Psychology, 74, 805-814.

Saleh, S., \& Hosek, J. (1976). Job involvement: Concepts and measurements. Academy of Management Journal, 19, 213-224.

Schmitt, N., White, J. K., Coyle, B. W., \& Rauschenberger, J. (1979). Retirement and life satisfaction. Academy of Management Journal, 22, 282-291. 
Schuler, R. S. (1977). Moderating effects of job involvement and growth need strength on task-outcome relationships. Journal of Business Research, 5, 293-309.

Seashore, S. E., Lawler, E. E., Mirvis, P., \& Cammann, C. (Eds.). (1982). Observing and measuring organizational change: A guide to field practice. New York: Wiley.

Shore, L. M., \& Martin, H. J. (1989). Job satisfaction and organizational commitment in relation to work performance and turnover intentions. Human Relations, 42, 625-638.

Shore, L. M., Tetrick, L. E., Sinclair, R. R., \& Newton, L. A. (1994). Validation of a measure of perceived union support. Journal of Applied Psychology, 79, 971-977.

Silverthorne, C. (2001). Leadership effectiveness and personality: A cross cultural evaluation. Personality and Individual Differences, 30, 303-309.

Smith, P. C., Kendall, L. M., \& Hulin, C. L. (1969). The measurement of satisfaction in work and retirement: A strategy for the study of attitudes. Chicago: Rand McNally.

Spector, P. E. (1988). Development of the Work Locus of Control Scale. Journal of Occupational Psychology, 61, 335-340.

Steers, R. M. (1977). Antecedents and outcomes of organizational commitment. Administrative Science Quarterly, 22, 46-56.

Steers, R. M., \& Rhodes, S. R. (1978). Major influences on employee attendance: A process model. Journal of Applied Psychology, 63, 391-407.

Taylor, J. C., \& Bowers, D. G. (1972). Survey of Organizations: A Machine Scored Standardized Questionnaire Instrument. Ann Arbor: Institute for Social Research, University of Michigan.

Tett, R. P., \& Meyer, J. P. (1993). Job satisfaction, organizational commitment, turnover intention, and turnover: Path analyses based on meta-analytic findings. Personnel Psychology, 46, 259-293.

Ting, Y. (1996). Analysis of job satisfaction of the federal white-collar work force: Findings from the Survey of Federal Employees. American Review of Public Administration, 26, 439-456.

Ting, Y. (1997). Determinants of job satisfaction of federal government employees. Public Personnel Management, 26, 313-334. 
Trevor, C. O., Gerhart, B., \& Boudreau, J. W. (1997). Voluntary turnover and job performance: Curvilinearity and the moderating influences of salary growth and promotions. Journal of Applied Psychology, 82, 44-61.

Valecha, G. K. (1972). Construct validation of internal-external locus of reinforcement related to work-related variables. Proceedings of the Annual Convention of the American Psychological Association, 7, 455-456.

Van Scotter, J. R., \& Motowidlo, S. J. (1996). Interpersonal facilitation and job dedication as separate facts of contextual performance. Journal of Applied Psychology. $\underline{81}, 525-531$.

Viswesvaran, C., \& Ones, D. S. (1995). Theory testing: Combining psychometric meta-analysis and structural equations modeling. Personnel Psychology, 48, 865-885.

Viswesvaran, C., Ones, D. S., \& Schmidt, F. L. (1996). Comparative analysis of the reliability of job performance ratings. Journal of Applied Psychology, 81, 557-574.

Wallace, J. E. (1993). Professional and organizational commitment: Compatible or incompatible? Journal of Vocational Behavior, 42, 333-349.

Wanberg, C. R., Kanfer, R., \& Rotundo, M. (1999). Unemployed individuals: Motives, job-search competencies, and job-search constraints as predictors of job seeking and reemployment. Journal of Applied Psychology, 84, 897-910.

Warr, P., Cook, J., \& Wall, T. (1979). Scales for the measurement of some work attitudes and aspects of psychological well-being. Journal of Occupational Psychology, 52, 129-148.

Weber, M. (1905). The Protestant ethic and the spirit of Capitalism. New York: Scribners.

Weiss, D. J., Dawis, R. V., \& England, G. W. (1967). Manual for the Minnesota Satisfaction Questionnaire. Minnesota Studies in Vocational Rehabilitation, 22, 120.

Wiener, Y., \& Vardi, Y. (1980). Relationships between job, organization, and career commitments and work outcomes: An integrative approach. Organizational Behavior and Human Performance, 26, 81-96.

Williams, L. J., \& Hazer, J. T. (1986). Antecedents and consequences of satisfaction and commitment in turnover models: A reanalysis using latent variable structural equation methods. Journal of Applied Psychology, 71, 219-231. 
Zellars, K. L., \& Kacmar, K. M. (1999). The influence of individual differences on reactions to c-workers' ingratiatory behaviors. Journal of Managerial Issues, 11, 234-248. 


\section{APPENDIX A \\ Potential Moderators Worth Exploring}

While there is no strong theoretical proof for the following moderator effects, I believe that these are potential moderators worth exploring:

In the CPO dimension, it appears that self-esteem might serve as a moderator between CPO and outcome variables (Gould, 1979).

Potential Hypothesis 1: Self-esteem (e.g., high versus low) will serve as a moderator in the: (a) CPO-job satisfaction relationship, such that the relationship will be stronger for employees with high self-esteem; (b) CPOjob performance relationship, such that the relationship will be stronger for employees with high self-esteem; and (c) CPO-turnover relationship, such that the relationship will be stronger for employees with low self-esteem.

In the job involvement dimension, it appears that locus of control might serve as a moderator between job involvement dimensions and outcome variables (Morrow, 1983).

Potential Hypothesis 2: Locus of control (e.g., internal versus external) will serve as a moderator in the: (a) job involvement-job satisfaction relationship, such that the relationship will be stronger for employees with high internal locus of control; (b) job involvement-job performance relationship, such that the relationship will be stronger for employees with a high internal locus of control; (c) job involvement-turnover relationship, such that the relationship will be stronger for employees with high external locus of control. 
Finally, age of employee might also serve as a moderator with job involvement and various outcome variables (cf. Cohen, 1991; Morrow, 1983).

Potential Hypothesis 3: Age of employee will serve as a moderator in the:

(a) job involvement-job satisfaction relationship, such that the relationship will be stronger for older employees; (b) job involvement-job performance relationship, such that the relationship will be stronger for older employees; (c) job involvement-turnover relationship, such that the relationship will be stronger for younger employees.

As mentioned at the beginning of Chapter IV, all of the analyses with self-esteem and locus of control were dropped from the analysis. Hence, the only potential hypothesis that could be tested was Potential Hypothesis 3, stated above. This potential hypothesis was not supported.

With the job involvement-job satisfaction relationship, the confidence interval for the older distribution varied from -.28 to .86 . The confidence interval for the younger distribution ranged form -.19 to .89 . Since there is overlap among the confidence intervals, there is not enough evidence to support a moderator effect here. Similarly, there is overlap among the confidence intervals for the other relationships of interest. With job involvement-job performance, the older distribution has a confidence interval of -.09 to .33 , while the younger distribution has a confidence interval of -.05 to .67 . The job involvement-turnover relationship has a confidence interval of -.42 to .04 for the older distribution, while it has a confidence interval of -.25 to -.07 for the younger distribution. Finally, in the job involvement-turnover intent relationship, the older distribution's 
confidence interval ranged from -.53 to -.03 . The confidence interval for the younger distribution varies from -.61 to -.05 . In each of these instances, there is overlap among the respective confidence intervals, indicating lack of support for a moderator effect. 


\section{APPENDIX B}

\section{Articles Used in Meta-Analysis}

Abdel-Halim, A. A. (1979). Individual and interpersonal moderators of employee reactions to job characteristics: A reexamination. Personnel Psychology, 32, 121-137.

Abdel-Halim, A. A. (1982). Social support and managerial affective responses to job stress. Journal of Occupational Behaviour, 3, 281-295.

Abdulla, M. H. A., \& Shaw, J. D. (1999). Personal factors and organizational commitment: Main and interactive effects in the United Arab Emirates. Journal of Managerial Issues, 11, 77-93.

Abelson, M. A. (1983). The impact of goal change on prominent perceptions and behaviors of employees. Journal of Management, 9, 65-79.

Abraham, R. (1999). The impact of emotional dissonance on organizational commitment and intention to turnover. Journal of Psychology, 133, 441-455.

Abrams, D., Ando, K., \& Hinkle, S. (1998). Psychological attachment to the group: Cross-cultural differences in organizational identification and subjective norms as predictors of workers' turnover intentions. Personality and Social Psychology Bulletin, 24, 1027-1039.

Adams, G. A. (1999). Career-related variables and planned retirement age: An extension of Beehr's model. Journal of Vocational Behavior, 55, 221-235.

Adams, G. A., \& Beehr, T. A. (1998). Turnover and retirement: A comparison of their similarities and differences. Personnel Psychology, 51, 643-665.

Adams, G. A., King, L. A., \& King, D. W. (1996). Relationships of job and family involvement, family social support, and work-family conflict with job and life satisfaction. Journal of Applied Psychology, 81, 411-420.

Adkins, C. L. (1995). Previous work experience and organizational socialization: A longitudinal examination. Academy of Management Journal, 38, 839-862.

Ahmad, S., \& Khanna, P. (1992). Job stress and job satisfaction of middle level hotel employees. Journal of Personality and Clinical Studies, 8, 51-56.

Al-Aameri, A. S. (2000). Job satisfaction and organizational commitment for nurses. Saudi Medical Journal, 21, 531-535. 
Aldag, R. J., \& Brief, A. P. (1975). Some correlates of work values. Journal of Applied Psychology, 60, 757-760.

Ali, A. J., \& Azim, A. (1995). Work ethic and loyalty in Canada. Journal of Social Psychology, 135, 31-37.

Allen, N. J., \& Meyer, J. P. (1990). The measurement and antecedents of affective, continuance and normative commitment to the organization. Journal of Occupational Psychology, 63, 1-18.

Allen, N. J., \& Meyer, J. P. (1993). Organizational commitment: Evidence of career stage effects? Journal of Business Research, 26, 49-61.

Allen, T. D. (2001). Family-supportive work environments: The role of organizational perceptions. Journal of Vocational Behavior, 58, 414-435.

Allen, T. D., Freeman, D. M., Russell, J. E. A., Reizenstein, R. C., \& Rentz, J. O. (2001). Survivor reactions to organizational downsizing: Does time ease the pain? Journal of Occupational and Organizational Psychology, 74, 145-164.

Allen, T. D., Poteet, M. L., \& Russell, J. E. A. (1998). Attitudes of managers who are more or less career plateaued. Career Development Quarterly, 47, 159-172.

Allen, T. D., \& Rush, M. C. (1998). The effects of organizational citizenship behavior on performance judgments: A field study and a laboratory experiment. Journal of Applied Psychology, 83, 247-260.

Allen, W. R., Drevs, R. A., \& Ruhe, J. A. (1999). Reasons why college-educated women change employment. Journal of Business and Psychology, 14, 77-93.

Alnajjar, A. A. (1996). Relationship between job satisfaction and organizational commitment among employees in the United Arab Emirates. Psychological Reports, 79, 315-321.

Angle, H. L., \& Lawson, M. B. (1993). Changes in affective and continuance commitment in times of relocation. Journal of Business Research, 26, 3-15.

Angle, H. L., \& Lawson, M. B. (1994). Organizational commitment and employees' performance ratings: Both type of commitment and type of performance count. Psychological Reports, 75, 1539-1551.

Angle, H. L., \& Perry, J. L. (1986). Dual commitment and labor-management relationship climates. Academy of Management Journal, 29, 31-50. 
Aranya, N., Barak, A., \& Amernic, J. A test of Holland's theory in a population of accountants. Journal of Vocational Behavior, 19, 15-24.

Aranya, N., \& Ferris, K. R. (1983). Organizational-professional conflict among U.S. and Israeli professional accountants. Journal of Social Psychology, 119, 153-161.

Aranya, N., Kushnir, T., \& Valency, A. (1986). Organizational commitment in a male-dominated profession. Human Relations, 39, 433-448.

Aranya, N., \& Wheeler, J. T. (1986). Accountants' personality types and their commitment to organization and profession. Contemporary Accounting Research, 3, 184199.

Armstrong-Stassen, M. (1993). Production workers' reactions to a plant closing: The role of transfer, stress, and support. Anxiety, Stress, and Coping, 6, 201-214.

Arnold, H. J., \& Feldman, D. C. (1982). A multivariate analysis of the determinants of job turnover. Journal of Applied Psychology, 67, 350-360.

Arnold, H. J., Feldman, D. C., \& Purbhoo, M. (1985). The role of socialdesirability response bias in turnover research. Academy of Management Journal, 28, 955-966.

Arnold, J., \& Mackenzie Davey, K. (1999). Graduates' work experiences as predictors of organisational commitment, intent to leave, and turnover: Which experiences really matter? Applied Psychology: An International Review, 48, 211-228.

Aryee, S. (1994). Job involvement: An analysis of its determinants among male and female teachers. Canadian Journal of Administrative Sciences, 11, 320-330.

Aryee, S., Chay, Y. W., \& Chew, J. (1994). An investigation of the predictors and outcomes of career commitment in three career stages. Journal of Vocational Behavior, 44, 1-16.

Aryee. S., \& Debrah, Y. A. (1993). A cross-cultural application of a career planning model. Journal of Organizational Behavior, 14, 119-127.

Aryee, S., \& Debrah, Y. A. (1997). Members' participation in the union: An investigation of some determinants in Singapore. Human Relations, 50, 129-147.

Aryee, S., \& Heng, L. J. (1990). A note on the applicability of an organizational commitment model. Work and Occupations, 17, 229-239. 
Aryee, S., Luk, V., \& Stone, R. (1998). Family-responsive variables and retention-relevant outcomes among employed parents. Human Relations, 51, 73-87.

Aryee, S., \& Tan, K. (1992). Antecedents and outcomes of career commitment. Journal of Vocational Behavior, 40, 288-305.

Aryee, S., Wyatt, T., \& Min, M. K. (1991). Antecedents of organizational commitment and turnover intentions among professional accountants in different employment settings in Singapore. Journal of Social Psychology, 131, 545-556.

Ashforth, B. E. (1989). The experience of powerlessness on organizations. Organizational Behavior and Human Decision Processes, 43, 207-242.

Ashforth, B. E., \& Saks, A. M. (1996). Socialization tactics: Longitudinal effects on newcomer adjustment. Academy of Management Journal, 39, 149-178.

Ashforth, B. E., Saks, A. M., \& Lee, R. T. (1997). On the dimensionality of Jones' (1986) measures of organizational socialization tactics. International Journal of Selection and Assessment, 5, 200-214.

Awal, D., \& Stumpf, S. A. (1981). Differentiating between perceived organization and work group climates. Journal of Management, 7, 33-42.

Baack, D., Luthans, F., \& Rogers, J. (1993). Analysis of the organizational commitment of clergy members. Journal of Managerial Issues, 5, 232-253.

Baba, V. V., \& Jamal, M. (1991). Routinization of job context and job content as related to employees' quality of working life: A study of Canadian nurses. Journal of Organizational Behavior, 12, 379-386.

Babakus, E., Cravens, D. W., Johnston, M., \& Moncrief, W. C. (1996). Examining the role of organizational variables in the salesperson job satisfaction model. Journal of Personal Selling and Sales Management, 16, 33-46.

Babakus, E., Cravens, D. W., Johnston, M., \& Moncrief, W. C. (1999). The role of emotional exhaustion in sales force attitude and behavior relationships. Journal of the Academy of Marketing Science, 27, 58-70.

Babu, P. P., \& Reddy, K. S. (1989). Work ethic religiosity and job involvement of employees under difference managements. Indian Journal of Applied Psychology, 26, 3037. 
Baker, J. G., \& Baker, D. F. (1999), Perceived ideological differences, job satisfaction and organizational commitment among psychiatrists in a community mental health center. Community Mental Health Journal, 35, 85-95.

Balaji, C. (1985). Organizational commitment and satisfaction of professionals and nonprofessionals in cooperatives. Vikalpa, 10, 35-41.

Ball, G. A., Trevino, L. K., \& Sims, Jr., H. P. (1993). Justice and organizational punishment: Attitudinal outcomes of disciplinary events. Social Justice Research, 6, 3967.

Bardsley, J. J., \& Rhodes, S. R. (1996). Using the Steers-Rhodes (1984) framework to identify correlates of employee lateness. Journal of Business and Psychology, 10, 351-365.

Barling, J. (1986). Fathers' work experiences, the father-child relationship and children's behaviour. Journal of Occupational Behaviour, 7, 61-66.

Barling, J., Bluen, S. D., \& Fain, R. (1987). Psychological functioning following an acute disaster. Journal of Applied Psychology, 72, 683-690.

Barling, J., Fullager, C., Kelloway, E. K., \& McElvie, L. (1992). Union loyalty and strike propensity. Journal of Social Psychology, 132, 581-590.

Barling, J., \& Kelloway, E. K. (1996). Job insecurity and health: The moderating role of workplace control. Stress Medicine, 12, 253-259.

Barling, J., \& Kryl, I. P. (1990). Moderators of the relationship between daily work stressors and mood. Work and Stress, 4, 319-329.

Barling, J., \& Rosenbaum, A. (1986). Work stressors and wife abuse. Journal of Applied Psychology, 71, 346-348.

Barling, J., Wade. B., \& Fullager, C. (1990). Predicting employee commitment to company and union: Divergent models. Journal of Occupational Psychology, 63, 49-61.

Barrick, M. R., Mount, M. K., \& Strauss, J. P. (1994). Antecedents of involuntary turnover due to a reduction in force. Personnel Psychology, 47, 515-535.

Bashaw, R. E., \& Grant, E. S. (1994). Exploring the distinctive nature of work commitments: Their relationships with personal characteristics, job performance, and propensity to leave. Journal of Personal Selling and Sales Management, 14, 41-56. 
Bateman, T. S., \& Strasser, S. (1984). A longitudinal analysis of the antecedents of organizational commitment. Academy of Management Journal, 27, 95-112.

Batlis, N. C. (1980). Job involvement and locus of control as moderators of roleperception/individual-outcome relationships. Psychological Reports, 46, 111-119.

Bauer, T. N., \& Green, S. G. (1998). Testing the combined effects of newcomer information seeking and manager behavior on socialization. Journal of Applied Psychology, 83, 72-83.

Baugh, S. G., Lankau, M. J., \& Scandura, T. A. (1996). An investigation of the effects of protégé gender on responses to mentoring. Journal of Vocational Behavior, 49 , 309-323.

Baugh, S. G., \& Scandura, T. A. (1999). The effect of multiple mentors on protege attitudes toward the work setting. Journal of Social Behavior and Personality, 14 , 503-521.

Beauvais, L. L., Scholl, R. W., \& Cooper, E. A. (1991). Dual commitment among unionized faculty: A longitudinal investigation. Human Relations, 44, 175-192.

Becker, T. E. (1992). Foci and bases of commitment: Are they distinctions worth making? Academy of Management Journal, 35, 232-244.

Becker, T. E., \& Billings, R. S. (1993). Profiles of commitment: An empirical test. Journal of Organizational Behavior, 14, 177-190.

Becker, T. E., Billings, R. S., Eveleth, D. M., \& Gilbert, N. L. (1996). Foci and bases of employee commitment: Implications for job performance. Academy of Management Journal, 39, 464-482.

Bedeian, A. G., Kemery, E. R., \& Pizzolatto, A. B. (1991). Career commitment and expected utility of present job as predictors of turnover intentions and turnover behavior. Journal of Vocational Behavior, 39, 331-343.

Bedeian, A. G., Pizzolatto, A. B., Long, R. G., \& Griffeth, R. W. (1991). The measurement and conceptualization of career stages. Journal of Career Development, 17, 153-156.

Beehr, T.A., \& Gupta, N. (1978). A note on the structure of employee withdrawal. Organizational Behavior and Human Performance, 21, 73-9. 
Begley, T. M., \& Czajka, J. M. (1993). Panel analysis of the moderating effects of commitment on job satisfaction, intent to quit, and health following organizational change. Journal of Applied Psychology, 78, 552-556.

Bemmels, B. (1995). Dual commitment: Unique construct or epiphenomenon? Journal of Labor Research, 16, 401-422.

Ben-Bakr, K. A., Al-Shammari, I. S., Jefri, O. A., \& Prasad, J. N. (1994). Organizational commitment, satisfaction, and turnover in Saudi organizations: A predictive study. The Journal of Socio-Economics, 23, 449-456.

Ben-Porat, A. (1980). Job involvement, central life interest, and job satisfaction. Psychological Reports, 46, 507-512.

Ben-Sira, Z. (1986). The plight of primary medical care: The problematics of 'committedness' to the practice. Social Science and Medicine, 22, 699-712.

Beutell, N. J., \& Wittig-Berman, U. (1999). Predictors of work-family conflict and satisfaction with family, job, career, and life. Psychological Reports, 85, 893-903.

Bhagat, R. S., McQuaid, S. J., Lindholm, H., \& Segovis, J. (1985). Total life stress: A multimethod validation of the construct and its effects on organizationally valued outcomes and withdrawal behaviors. Journal of Applied Psychology, 70, 202-214.

Bhalla, S., Jones, B., \& Flynn, D. M. (1991). Role stress among Canadian whitecollar workers. Work and Stress, 5, 289-299.

Bhatt, D. J. (1997). Job stress, job involvement and job satisfaction of teachers: A correlational study. Indian Journal of Psychometry and Education, 28, 87-94.

Bigoness, W. J. (1978). Correlates of faculty attitudes toward collective bargaining. Journal of Applied Psychology, 63, 228-233.

Billingsley, B. S., \& Cross, L. H. (1992). Predictors of commitment, job satisfaction, and intent to stay in teaching: A comparison of general and special educators. Journal of Special Education, 25, 453-471.

Birdi, K., Allan, C., \& Warr, P. (1997). Correlates and perceived outcomes of four types of employee development activity. Journal of Applied Psychology, 82, 845857.

Bishop, J. W., \& Scott, K. D. (2000). An examination of organizational and team commitment in a self-directed team environment. Journal of Applied Psychology, 85, 439450 . 
Bishop, J. W., Scott, K. D., \& Burroughs, S. M. (2000). Support, commitment, and employee outcomes in a team environment. Journal of Management, 26, 1113-1132.

Blau, G. (1988). An investigation of the apprenticeship organizational socialization strategy. Journal of Vocational Behavior, 32, 176-195.

Blau, G. (1989). Testing the generalizability of a career commitment measure and its impact on employee turnover. Journal of Vocational Behavior, 35, 88-103.

Blau, G. (1993). Further exploring the relationship between job search and voluntary individual turnover. Personnel Psychology, 46, 313-330.

Blau, G. (1994). Developing and testing a taxonomy of lateness behavior. Journal of Applied Psychology, 79, 959-970.

Blau, G. (1994). Further evidence for the discriminant validity of four facets of work commitment: Occupation, value, organization, and job. Perceptual and Motor Skills, 79, 1617-1618.

Blau, G. (1994). Testing a two-dimensional measure of job search behavior. Organizational Behavior and Human Decision Processes, 59, 288-312.

Blau, G. (1999). Early-career job factors influencing the professional commitment of medical technologists. Academy of Management Journal, 42, 687-695.

Blau, G. (2000). Job, organizational, and professional context antecedents as predictors of intent for interrole work transitions. Journal of Vocational Behavior, 56, 330-345.

Blau, G. (2001). Testing the discriminant validity of occupational entrenchment. Journal of Occupational and Organizational Psychology, 74, 85-93.

Blau, G., \& Boal, K. (1989). Using job involvement and organizational commitment interactively to predict turnover. Journal of Management, 15, 115-127.

Blau, G. J. (1985). Relationship of extrinsic, intrinsic, and demographic predictors to various types of withdrawal behaviors. Journal of Applied Psychology, 70, 442-450.

Blau, G. J. (1985). The measurement and prediction of career commitment. Journal of Occupational Psychology, 58, 277-288.

Blau, G. J. (1986). Job involvement and organizational commitment as interactive predictors of tardiness and absenteeism. Journal of Management, 12, 577-584. 
Blau, G. J. (1988). Further exploring the meaning and measurement of career commitment. Journal of Vocational Behavior, 32, 284-297.

Blau, G., \& Lunz, M. (1998). Testing the incremental effect of professional commitment on intent to leave one's profession beyond the effects of external, personal, and work-related variables. Journal of Vocational Behavior, 52, 260-269.

Blau, G., Paul, A., \& St. John, N. (1993). On developing a general index of work commitment. Journal of Vocational Behavior, 42, 298-314.

Blegen, M. A., Mueller, C. W., \& Price, J. L. (1988). Measurement of kinship responsibility for organizational research. Journal of Applied Psychology, 73, 402-409.

Bloom, P. J. (1996). The quality of work life in NAEYC accredited and nonaccredited early childhood programs. Early Education and Development, 7, 301-317.

Bluedorn, A. C. (1982). A unified model of turnover from organizations. Human Relations, 35, 135-153.

Blumberg, M. (1980). Job switching in autonomous work groups: An exploratory study in a Pennsylvania coal mine. Academy of Management Journal, 23, 287-306.

Bolino, M. C., \& Feldman, D. C. (2000). The antecedents and consequences of underemployment among expatriates. Journal of Organizational Behavior, 21, 889-911.

Bolon, D. S. (1997). Organizational citizenship behavior among hospital employees: A multidimensional analysis involving job satisfaction and organizational commitment. Hospital and Health Services Administration, 42, 221-241.

Borg, M. G., Riding, R. J., \& Falzon, J. M. (1991). Stress in teaching: A study of occupational stress and its determinants, job satisfaction and career commitment among primary schoolteachers. Educational Psychology, 11, 59-75.

Borucki, Z. (1987). Perceived organizational stress, emotions, and negative consequences of stress: Global self-esteem and sense of interpersonal competence as moderator variables. Polish Psychological Bulletin, 18, 139-148.

Bozeman, D. P., Perrewe, P. L., Hochwarter, W. A., \& Brymer, R. A. (2001). Organizational politics, perceived control, and work outcomes: Boundary conditions on the effects of politics. Journal of Applied Social Psychology, 31, 486-503.

Breaugh, J. A. (1981). Predicting absenteeism from prior absenteeism and work attitudes. Journal of Applied Psychology, 66, 555-560. 
Breaugh, J. A. (1981). Relationships between recruiting sources and employee performance, absenteeism, and work attitudes. Academy of Management Journal, 24, 142-147.

Brett, J. F., Cron, W. L., \& Slocum, J. W., Jr. (1995). Economic dependency on work: A moderator of the relationship between organizational commitment and performance. Academy of Management Journal, 38, 261-271.

Brewer, A. M., \& Hensher, D. A. (1998). The importance of organisational commitment in managing change: Experience of the NSW private bus industry. Transportation Research Part E: Logistics and Transportation Review, 34, 117-130.

Brief, A. P., \& Aldag, R. J. (1977). Work values as moderators of perceived leader behavior-satisfaction relationships. Sociology of Work and Occupations, 4, 99112.

Brief, A. P., Van Sell, M., \& Aldag, R. J. (1978). Job scope-employee reaction relationships: Methodological considerations. Journal of Management, 4, 27-32.

Brierley, J. A. (1996). The measurement of organizational commitment and professional commitment. Journal of Social Psychology, 136, 265-267.

Brockner, J., Grover, S. L., \& Blonder, M. D. (1988). Predictors of survivors' job involvement following layoffs: A field study. Journal of Applied Psychology, 73, 436-442.

Brockner, J., Tyler, T. R., \& Cooper-Schneider, R. (1992). The influence of prior commitment to an institution on reactions to perceived unfairness: The higher they are, the harder they fall. Administrative Science Quarterly, 37, 241-261.

Brockner, J., Wiesenfeld, B. M., Reed, T., Grover, S., \& Martin, C. (1993). Interactive effect of job content and context on the reactions of layoff survivors. Journal of Personality and Social Psychology, 64, 187-197.

Brooke, P. P., Jr., Russell, D. W., \& Price, J. L. (1988). Discriminant validation of measures of job satisfaction, job involvement, and organizational commitment. Journal of Applied Psychology, 73, 139-145.

Brown, S. P., Cron, W. L., \& Leigh, T. W. (1993). Do feelings of success mediate sales performance-work attitude relationships? Journal of the Academy of Marketing Science, 21, 91-100.

Brown, S. P., Cron, W. L., \& Slocum, J. W., Jr. (1998). Effects of trait competitiveness and perceived intraorganizational competition on salesperson goal setting and performance. Journal of Marketing, 62, 88-98. 
Brown, S. P., \& Leigh, T. W. (1996). A new look at psychological climate and its relationship to job involvement, effort, and performance. Journal of Applied Psychology, 81, 358-368.

Bruning, N. S., \& Snyder, R. A. (1983). Sex and position as predictors of organizational commitment. Academy of Management Journal, 26, 485-491.

Buchko, A. A. (1992). Effects of employee ownership on employee attitudes: A test of three theoretical perspectives. Work and Occupations, 19, 59-78.

Buchko, A. A. (1992). Employee ownership, attitudes, and turnover: An empirical assessment. Human Relations, 45, 711-733.

Buchko, A. A. (1993). The effects of employee ownership on employee attitudes: An integrated causal model and path analysis. Journal of Management Studies, 30, 633657.

Buchko, A. A., Weinzimmer, L. G., \& Sergeyev, A. V. (1997). A comparative analysis of organizational commitment between workers in the United States and Russia. Journal of Managerial Issues, 9, 204-215.

Buchko, A. A., Weinzimmer, L. G., \& Sergeyev, A. V. (1998). Effects of cultural context on the antecedents, correlates, and consequences of organizational commitment: A study of Russian workers. Journal of Business Research, 43, 109-116.

Buckley, M. R., Fedor, D. B., Veres, J. G., Wiese, D. S., \& Carraher, S. M. (1998). Investigating newcomer expectations and job-related outcomes. Journal of Applied Psychology, 83, 452-461.

Buffardi, L. C., \& Erdwins, C. J. (1997). Child-care satisfaction: Linkages to work attitudes, interrole conflict, and maternal separation anxiety. Journal of Occupational Health Psychology, 2, 84-96.

Burke, R. J., \& McKeen, C. A. (1995). Work experiences, career development, and career success of managerial and professional women. Journal of Social Behavior and Personality, 10, 81-96.

Burrows, L., Munday, R., Tunnell, J., \& Seay, R. (1996). Leadership substitutes: Their effects on teacher organizational commitment and satisfaction. Journal of Instructional Psychology, 23, 3-8.

Bycio, P., Hackett, R. D., \& Allen, J. S. (1995). Further assessments of Bass's (1985) conceptualization of transactional and transformational leadership. Journal of Applied Psychology, 80, 468-478. 
Carson, K. D., \& Bedeian, A. G. (1994). Career commitment: Construction of a measure and examination of its psychometric properties. Journal of Vocational Behavior, 44, 237-262.

Carson, K. D., \& Carson, P. P. (1998). Career commitment, competencies, and citizenship. Journal of Career Assessment, 6, 195-208.

Carson, K. D., Carson, P. P., \& Bedeian, A. G. (1995). Development and construct validation of a career entrenchment measure. Journal of Occupational and Organizational Psychology, 68, 301-320.

Carson, K. D., Carson, P. P., Lanford, H., \& Roe, C. W. (1997). The effects of organization-based self-esteem on workplace outcomes: An examination of emergency medical technicians. Public Personnel Management, 26, 139-155.

Cassar, V. (1999). Can leader direction and employee participation co-exist? Investigating interaction effects between participation and favourable work-related attitudes among Maltese middle-managers. Journal of Managerial Psychology, 14, 57-68.

Caught, K., Shadur, M. A., \& Rodwell, J. J. (2000). The measurement artifact in the organizational commitment questionnaire. Psychological Reports, 87, 777-788.

Chacko, T. I. (1982). Women and equal employment opportunity: Some unintended effects. Journal of Applied Psychology, 67, 119-123.

Chan, A. W., \& Snape, E. (2000). Union weakness in Hong Kong: Workplace industrial relations and the federation of trade unions. Economic and Industrial Democracy, 21, 117-146.

Chan, D. (2001). Method effects of positive affectivity, negative affectivity, and impression management in self-reports of work attitudes. Human Performance, 14, 77-96.

Chandrashekaran, M., McNeilly, K., Russ, F. A., \& Marinova, D. (2000). From uncertain intentions to actual behavior: A threshold model of whether and when salespeople quit. Journal of Marketing Research, 37, 463-479.

Chang, E. (1999). Career commitment as a complex moderator of organizational commitment and turnover intention. Human Relations, 52, 1257-1278.

Chapman, D. W., \& Green, M. S. (1986). Teacher retention: A further examination. Journal of Educational Research, 79, 273-279. 
Chassie, M. B., \& Bhagat, R. S. (1980). Role stress in working women: Differential effect on selected organizational outcomes. Group and Organization Studies, 5, 224-233.

Chay, Y., \& Aryee, S. (1999). Potential moderating influence of career growth opportunities on careerist orientation and work attitudes: Evidence of the protean career era in Singapore. Journal of Organizational Behavior, 20, 613-623.

Chelte, A. F., \& Tausky, C. (1987). A note on organizational commitment: Antecedents and consequences among managers, professionals, and blue-collar workers. Work and Occupations, 13, 553-561.

Cheloha, R. S., \& Farr, J. L. (1980). Absenteeism, job involvement, and job satisfaction in an organizational setting. Journal of Applied Psychology, 65, 467-473.

Chen, Z. X., \& Francesco, A. M. (2000). Employee demography, organizational commitment, and turnover intentions in China: Do cultural differences matter? Human Relations, 53, 869-887.

Cheng, E.W.L. (2000). Test of the MBA knowledge and skills transfer. International Journal of Human Resource Management, 11, 837-852.

Cherniss, C. (1991). Career commitment in human service professionals: A biographical study. Human Relations, 44, 419-437.

Chiu, W. C. K., \& Ng, C. W. (1999). Women-friendly HRM and organizational commitment: A study among women and men of organizations in Hong Kong. Journal of Occupational and Organizational Psychology, 72, 485-502.

Chonko, L. B. (1983). Job involvement as obsession-compulsion: Some preliminary empirical findings. Psychological Reports, 53, 1191-1197.

Chusmir, L. H., \& Hood, J. A. (1986). Relationship between Type A behaviors pattern and motivational needs. Psychological Reports, 58, 783-794.

Chusmir, L. H., \& Koberg, C. S. (1986). Development and validation of the sex role conflict scale. Journal of Applied Behavioral Science, 22, 397-409.

Chusmir, L. H., \& Koberg, C. S. (1988). A look at sex differences in the relationships between religious beliefs and work-related attitudes. Journal of Social Behavior and Personality, 3, 37-48.

Chusmir, L. H., \& Koberg, C. S. (1988). Religion and attitudes toward work: A new look at an old question. Journal of Organizational Behavior, 9, 251-262. 
Clegg, C. W. (1983). Psychology of employee lateness, absence, and turnover: A methodological critique and an empirical study. Journal of Applied Psychology, 68, 88101.

Cleveland, J. N., \& Shore, L. M. (1992). Self- and supervisory perspectives on age and work attitudes and performance. Journal of Applied Psychology, 77, 469-484.

Clugston, M. (2000). The mediating effects of multidimensional commitment on job satisfaction and intent to leave. Journal of Organizational Behavior, 21, 477-486.

Clugston, M., Howell, J. P., \& Dorfman, P. W. (2000). Does cultural socialization predict multiple bases and foci of commitment? Journal of Management, 26, 5-30.

Cohen, A. (1992). Attitudinal militancy and propensity to strike among unionized engineers and x-ray technicians. Human Relations, 45, 1333-1366.

Cohen, A. (1993). An empirical assessment of the multidimensionality of union participation. Journal of Management, 19, 749-773.

Cohen, A. (1993). Work commitment in relation to withdrawal intentions and union effectiveness. Journal of Business Research, 26, 75-90.

Cohen, A. (1995). An examination of the relationships between work commitment and nonwork domains. Human Relations, 48, 239-263.

Cohen, A. (1996). On the discriminant validity of the Meyer and Allen measure of organizational commitment: How does it fit with the work commitment construct? Educational and Psychological Measurement, 56, 494-503.

Cohen, A. (1997). Nonwork influences on withdrawal cognitions: An empirical examination of an overlooked issue. Human Relations, 50, 1511-1536.

Cohen, A. (1998). An examination of the relationship between work commitment and work outcomes among hospital nurses. Scandinavian Journal of Management, 14, 117.

Cohen, A. (1999). Relationships among five forms of commitment: An empirical assessment. Journal of Organizational Behavior, 20, 285-308.

Cohen, A. (1999). The relation between commitment forms and work outcomes in Jewish and Arab culture. Journal of Vocational Behavior, 54, 371-391.

Cohen, A. (2000). The relationship between commitment forms and work outcomes: A comparison of three models. Human Relations, 53, 387-417. 
Cohen, A., \& Kirchmeyer, C. (1994). Unions and ethnic diversity: The Israeli case of East European immigrants. Journal of Applied Behavioral Science, 30, 141-158.

Cohen, A., \& Kirchmeyer, C. (1995). A multidimensional approach to the relation between organizational commitment and nonwork participation. Journal of Vocational Behavior, 46, 189-202.

Colarelli, S. M., \& Bishop, R. C. (1990). Career commitment: Functions, correlates, and management. Group and Organization Studies, 15, 158-176.

Colarelli, S. M., Dean, R. A., \& Konstans, C. (1987). Comparative effects of personal and situational influences on job outcomes of new professionals. Journal of Applied Psychology, 72, 558-566.

Coleman, D. F., Irving, G. P., \& Cooper, C. L. (1999). Another look at the locus of control-organizational commitment relationship: It depends on the form of commitment. Journal of Organizational Behavior, 20, 995-1001.

Conlon, E. J., \& Gallagher, D. G. (1987). Commitment to employer and union: Effects of membership status. Academy of Management Journal, 30, 151-162.

Cook, J., \& Wall, T. (1980). New work attitude measures of trust, organizational commitment and personal need non-fulfilment. Journal of Occupational Psychology, 53, 39-52.

Cooke, D. K. (1997). Discriminant validity of the Organizational Commitment Questionnaire. Psychological Reports, 80, 431-441.

Cordero, R., Farris, G. F., \& DiTomaso, N. (1998). Technical professionals in cross-functional teams: Their quality of work life. Journal of Product Innovation Management, 15, 550-563.

Cosier, R. A., \& Dalton, D. R. (1990). Positive effects on conflict: A field assessment. The International Journal of Conflict Management, 1, 81-92.

Cox, T. H., \& Nkomo, S. M. (1991). A race and gender-group analysis of the early career experience of MBAs. Work and Occupations, 18, 431-446.

Cramer, D. (1996). Job satisfaction and organizational continuance commitment: A two-wave panel study. Journal of Organizational Behavior, 17, 389-400.

Crohan, S. E., Antonucci, T. C., \& Adelman, P. K. (1989). Job characteristics and well-being at midlife: Ethnic and gender comparisons. Psychology of Women Quarterly, 13, 223-235. 
Cropanzano, R., Howes, J. C., Grandey, A. A., \& Toth, P. (1997). The relationship of organizational politics and support to work behaviors, attitudes, and stress. Journal of Organizational Behavior, 18, 159-180.

Cropanzano, R., James, K., \& Konovsky, M. A. (1993). Dispositional affectivity as a predictor of work attitudes and job performance. Journal of Organizational Behavior, $14,595-606$.

Cross, L. H., \& Billingsley, B. S. (1994). Testing a model of special educators' intent to stay in teaching. Exceptional Children, 60, 411-421.

Currivan, D. B. (1999). The causal order of job satisfaction and organizational commitment in models of employee turnover. Human Resource Management Review, 9 , 495-524.

Curry, J. P., Wakefield, D. S., Price, J. L., \& Mueller, C. W. (1986). On the causal ordering of job satisfaction and organizational commitment. Academy of Management Journal, 29, 847-858.

Dailey, R. C. (1978). Antecedents of performance for scientists and engineers: A path analytic study. Review of Business and Economic Research, 14, 37-46.

Dailey, R. C. (1986). Understanding organizational commitment for volunteers: Empirical and managerial implications. Journal of Voluntary Action Research, 15, 19-31.

Dailey, R. C., \& Kirk, D. J. (1992). Distributive and procedural justice as antecedents of job dissatisfaction and intent to turnover. Human Relations, 45, 305-317.

Dalton, D. R., \& Mesch, D. J. (1991). On the extent and reduction of avoidable absenteeism: An assessment of absence policy provisions. Journal of Applied Psychology, 76, 810-817.

Dalton, D. R., \& Todor, W. D. (1982). Antecedents of grievance filing behavior: Attitude/behavioral consistency and the union steward. Academy of Management Journal, 25, 158-169.

Dalton, D. R., \& Todor, W. D. (1982). Union steward locus of control, job, union involvement, and grievance behavior. Journal of Business Research, 10, 85-101.

Darden, W. R., Hampton, R., \& Howell, R. D. (1989). Career versus organizational commitment: Antecedents and consequences of retail salespeoples' commitment. Journal of Retailing, 65, 80-106. 
Davy, J. A., Kinicki, A. J., \& Scheck, C. L. (1991). Developing and testing a model of survivor responses to layoffs. Journal of Vocational Behavior, 38, 302-317.

Davy, J. A., Kinicki, A. J., \& Scheck, C. L. (1997). A test of job security's direct and mediated effects on withdrawal cognitions. Journal of Organizational Behavior, 18 , 323-349.

Day, N. E., \& Schoenrade, P. (1997). Staying in the closet versus coming out: Relationships between communication about sexual orientation and work attitudes. Personnel Psychology, 50, 147-163.

Day, N. E., \& Schoenrade, P. (2000). The relationship among reported disclosure of sexual orientation, anti-discrimination policies, top management support and work attitudes of gay and lesbian employees. Personnel Review, 29, 346-363.

DeCotiis, T. A., \& Summers, T. P. (1987). A path analysis of a model of the antecedents and consequences of organizational commitment. Human Relations, 40, 445470.

DeGroot, H. A., Burke, L. J., \& George, V. M. (1998). Implementing the differentiated pay structure model: Process and outcomes. Journal of Nursing Administration, 28, 28-38.

DeWitt, R., Trevino, L. K., \& Mollica, K. A. (1998). The influence of eligibility on employees' reactions to voluntary workforce reductions. Journal of Management, 24, 593-613.

Deery, S. J., Iverson, R. D., \& Erwin, P. J. (1994). Predicting organizational and union commitment: The effect of industrial relations climate. British Journal of Industrial Relations, 32, 581-597.

Delobbe, N., \& Vandenberghe, C. (2000). A four-dimensional model of organizational commitment among Belgian employees. European Journal of Psychological Assessment, 16, 125-138.

Dodd-McCue, D., \& Wright, G. B. (1996). Men, women, and attitudinal commitment: The effects of workplace experiences and socialization. Human Relations, 49, 1065-1091.

Dolen, M. R., \& Shultz, K. S. (1998). Comparison of organizational, professional, university, and academic commitment scales. Psychological Reports, 82, 1232-1234. 
Dolke, A. M., \& Srivastava, P. K. (1988). Need satisfaction, job involvement and intrinsic motivation: A factor analytical study. Indian Journal of Applied Psychology, 25, 13-17.

Donaldson, S. I., Sussman, S., Dent, C. W., Severson, H. H., \& Stoddard, J. L. (1999). Health behavior, quality of work life, and organizational effectiveness in the lumbar industry. Health Education and Behavior, 26, 579-591.

Dougherty, T. W., Bluedorn, A. C., \& Keon, T. L. (1985). Precursors of employee turnover: A multiple-sample causal analysis. Journal of Occupational Behaviour, 6, 259-271.

Drasgow, F., \& Miller, H. E. (1982). Psychometric and substantive issues in scale construction and validation. Journal of Applied Psychology, 67, 268-279.

Drory, A. (1981). Organizational stress and job attitudes: Moderating effects of organizational level and task characteristics. Psychological Reports, 49, 139-146.

Dubinsky, A. J., Kotabe, M., Lim, C. U., \& Wagner, W. (1997). The impact of values on salespeople's job responses: A cross-national investigation. Journal of Business Research, 39, 195-208.

Dubinsky, A. J., Michaels, R. E., Kotabe, M., Lim, C. U., \& Moon, H. (1992). Influence of role stress on industrial salespeople's work outcomes in the United States, Japan, and Korea. Journal of International Business Studies, 23, 77-99.

Dubinsky, A. J., \& Skinner, S. J. (1984). Impact of job characteristics on retail salespeople's reactions to their jobs. Journal of Retailing, 60, 35-62.

Dubinsky, A. J., \& Yammarino, F. J. (1985). Job-related responses of insurance agents: A multi-firm investigation. Journal of Risk and Insurance, 52, 501-517.

Dulebohn, J. H., \& Martocchio, J. J. (1998). Employee perceptions of the fairness of work group incentive pay plans. Journal of Management, 24, 469-488.

Eaton, A. E., Gordon, M. E., \& Keefe, J. H. (1992). The impact of quality of work life programs and grievance system effectiveness on union commitment. Industrial and Labor Relations Review, 45, 591-604.

Efraty, D., \& Sirgy, J. (1990). The effects of quality of working life (QWL) on employee behavioral responses. Social Indicators Research, 22, 31-47. 
Efraty, D., Sirgy, M. J., \& Claiborne, C. B. (1991). The effects of personal alienation on organizational identification: A quality-of-work-life model. Journal of Business and Psychology, 6, 57-76.

Eisenstat, R. A., \& Felner, R. D. (1984). Toward a differentiated view of burnout: Personal and organizational mediators of job satisfaction and stress. American Journal of Community Psychology, 12, 411-430.

Elfering, A., Semmer, N. K., \& Kalin, W. (2000). Stability and change in job satisfaction at the transition from vocational training into "real work." Swiss Journal of Psychology, 59, 256-271.

Ellemers, N., de Gilder, D., \& van den Heuvel, H. (1998). Career-oriented versus team-oriented commitment and behavior at work. Journal of Applied Psychology, 83, 717-730.

Ellis, B. H., \& Miller, K. I. (1993). The role of assertiveness, personal control, and participation in the prediction of nurse burnout. Journal of Applied Communication Research, 21, 327-342.

Elloy, D. F., Everett, J. E., \& Flynn, W. R. (1991). An examination of the correlates of job involvement. Group and Organization Studies, 16, 160-177.

Elloy, D. F., Everett, J. E., \& Flynn, W. R. (1995). Multidimensional mapping of the correlates of job involvement. Canadian Journal of Behavioural Science, 27, 79-91.

Evans, M. A. (1999). An analysis and cross-validation of the role of information during downsizing. Military Psychology, 11, 345-364.

Farkas, A. J., \& Tetrick, L. E. (1989). A three-wave longitudinal analysis of the causal ordering of satisfaction and commitment on turnover decisions. Journal of Applied Psychology, 74, 855-868.

Farrell, D., \& Rusbult, C. E. (1981). Exchange variables as predictors of job satisfaction, job commitment, and turnover: The impact of rewards, costs, alternatives, and investments. Organizational Behavior and Human Performance, 27, 28, 78-95.

Feldman, D. C. (1976). A contingency theory of socialization. Administrative Science Quarterly, 21, 433-452.

Feldman, D. C., \& Turnley, W. H. (1995). Underemployment among recent business college graduates. Journal of Organizational Behavior, 16, 691-706. 
Feldman, D. C., \& Weitz, B. A. (1991). From the invisible hand to the gladhand: Understanding a careerist orientation to work. Human Resource Management, 30, 237257.

Ferris, K.R. (1981). Organizational commitment and performance in a professional accounting firm. Accounting, Organizations and Society, 6, 317-325.

Ferris, K. R., \& Aranya, N. (1983). A comparison of two organization commitment scales. Personnel Psychology, 36, 87-98.

Fields, M. W., \& Thacker, J. W. (1992). Influence of quality of work life on company and union commitment. Academy of Management Journal, 35, 439-450.

Finegan, J. E. (2000). The impact of person and organizational values on organizational commitment. Journal of Occupational and Organizational Psychology, 73, 149-169.

Fisher, C. D. (1985). Social support and adjustment to work: A longitudinal study. Journal of Management, 11, 39-53.

Fitzgerald, L. F., Drasgow, F., \& Magley, V. J. (1999). Sexual harassment in the armed forces: A test of an integrated model. Military Psychology, 11, 329-343.

Fletcher, C. (1991). Candidates' reactions to assessment centers and their outcomes: A longitudinal study. Journal of Occupational Psychology, 64, 117-127.

Florkowski, G. W., \& Schuster, M. H. (1992). Support for profit sharing and organizational commitment: A path analysis. Human Relations, 45, 507-523.

Flynn, D. M., \& Solomon, E. (1985). Organizational commitment: A multivariate test within the banking industry. Psychological Reports, 57, 119-130.

Folger, R., \& Konovsky, M. A. (1989). Effects of procedural and distributive justice on reactions to pay raise decisions. Academy of Management Journal, 32, 115130.

Freeborn, D. K. (2001). Satisfaction, commitment, and psychological well-being among HMO physicians. Western Journal of Medicine, 174, 13-18.

French, J. L., \& Rosenstein, J. (1984). Employee ownership, work attitudes, and power relationships. Academy of Management Journal, 27, 861-869.

Fresko, B., Kfir, D., \& Nasser, F. (1997). Predicting teacher commitment. Teaching and Teacher Education, 13, 429-438. 
Frone, M. R. (2000). Interpersonal conflict at work and psychological outcomes: Testing a model among young workers. Journal of Occupational Health Psychology, 5, 246-255.

Frone, M. R., \& Major, B. (1988). Communication quality and job satisfaction among managerial nurses: The moderating influence of job involvement. Group and Organization Studies, 13, 332-347.

Fukami, C. V., \& Larson, E. W. (1984). Commitment to company and union: Parallel models. Journal of Applied Psychology, 69, 367-371.

Fullager, C. (1986). A factor analytic study on the validity of a union commitment scale. Journal of Applied Psychology, 71, 129-136.

Fullager, C., \& Barling, J. (1991). Predictors and outcomes of different patterns of organizational and union loyalty. Journal of Occupational Psychology, 64, 129-143.

Fullager, C., Barling, J., \& Christie, P. (1991). Dual commitment in aggressive and protective unions. Applied Psychology: An International Review, 40, 93-104.

Fullager, C., Clark, P., Gallagher, D., \& Gordon, M. E. (1994). A model of the antecedents of early union commitment: The role of socialization experiences and steward characteristics. Journal of Organizational Behavior, 15, 517-533.

Fullager, C. J. A., Gallagher, D. G. , Gordon, M. E., \& Clark, P. F. (1995). Impact of early socialization on union commitment and participation: A longitudinal study. Journal of Applied Psychology, 80, 147-157.

Fullager, C. J. A., Parks, J. M., Clark, P. F., \& Gallagher, D. G. (1995). Organizational citizenship and union participation: Measuring discretionary membership behaviors. In L.E. Tetrick \& J. Barling (Eds.), Changing employment relations: Behavioral and social perspectives (pp. 311-333). Washington, DC: APA.

Furnham, A. (1984). Work values and beliefs in Britain. Journal of Occupational Behaviour, 5, 281-191.

Furnham, A. (1990). The Protestant Work Ethic and Type A Behaviour: A Pilot Study. Psychological Reports, 66, 323-328.

Furnham, A. (1997). The half full or half empty glass: The views of economic optimist vs pessimist. Human Relations, 50, 197-209.

Furnham, A. (1997). The relationship between work and economic values. Journal of Economic Psychology, 18, 1-14. 
Furnham, A., Brewin, C. R., \& O'Kelly, H. (1994). Cognitive style and attitudes to work. Human Relations, 47, 1509-1521.

Gaither, C. A. (1993). Evaluating the construct validity of work commitment measures: A confirmatory factor model. Evaluation and the Health Professions, 16, 417433.

Ganesan, S., \& Weitz, B. A. (1996). The impact of staffing policies on retail buyer job attitudes and behaviors. Journal of retailing, 72, 31-56.

Gannon, M. J., \& Hendrickson, D. H. (1973). Career orientation and job satisfaction among working wives. Journal of Applied Psychology, 57, 339-340.

Ganster, D. C., \& Dwyer, D. J. (1995). The effects of understaffing on individual and group performance in professional and trade occupations. Journal of Management, 21, 175-190.

Gardner, D. G., Dunham, R. B., Cummings, L. L., \& Pierce, J. L. (1989). Focus of attention at work: Construct definition and empirical validation. Journal of Occupational Psychology, 62, 61-77.

Gechman, A. S., \& Wiener, Y. (1975). Job involvement and satisfaction as related to mental health and personal time devoted to work. Journal of Applied Psychology, 60, 521-523.

Gellatly, I. R. (1995). Individual and group determinants of employee absenteeism: Test of a causal model. Journal of Organizational Behavior, 16, 469-485.

George, J. M. (1995). Leader positive mood and group performance: The case of customer service. Journal of Applied Social Psychology, 25, 778-794.

Gerpott, T. J. (1990). Intracompany job transfers: An exploratory two-sample study of the buffering effects of interpersonal support. Prevention in Human Services, 8, 113-137.

Geurts, S. A., Schaufeli, W. B., \& Rutte, C. G. (1999). Absenteeism, turnover intention and inequity in the employment relationship. Work \& Stress, 13, 253-267.

Glisson, C., \& Durick, M. (1988). Predictors of job satisfaction and organizational commitment in human service organizations. Administrative Science Quarterly, 33, 61-81.

Goffin, R. D., \& Gellatly, I. R. (2001). A multi-rater assessment of organizational commitment: Are self-report measures biased? Journal of Organizational Behavior, 22, 437-451. 
Goldberg, W. A., Greenberger, E., Koch-Jones, J., O'Neil, R., \& Hamill, S. (1989). Attractiveness of child care related employer-supported benefits and policies to married and single parents. Child and Youth Care Quarterly, 18, 23-37.

Good, L. K., Sisler, G. F., \& Gentry, J. W. (1988). Antecedents of turnover intentions among retail management personnel. Journal of Retailing, 64, 295-315.

Gordon, M. E., Philpot, J. W., Burt, R. E., Thompson, C. A., \& Spiller, W. E. (1980). Commitment to the union: Development of a measure and an examination of its correlates. Journal of Applied Psychology, 65, 479-499.

Gorgievski-Duijvesteijn, M., Steensma, H., \& Brake, E. (1998). Protestant Work Ethic as a moderator of mental and physical well-being. Psychological Reports, 83, 10431050 .

Gorn, G. J., \& Kanungo, R. N. (1980). Job involvement and motivation: Are intrinsically motivated managers more job involved? Organizational Behavior and Human Performance, 26, 265-277.

Gottfredson, G. D., \& Holland, J. L. (1990). A longitudinal test of the influence of congruence: Job satisfaction, competency utilization, and counterproductive behavior. Journal of Counseling Psychology, 37, 389-398.

Graddick, M. M., \& Farr, J. L. (1983). Professionals in scientific disciplines: Sexrelated differences in working life commitments. Journal of Applied Psychology, 68, 641645 .

Graen, G. B., Wakabayashi, M., Graen, M. R., \& Graen, M. G. (1990). International generalizability of American hypotheses about Japanese management progress: A strong inference investigation. Leadership Quarterly, 1, 1-23.

Grant, K., Cravens, D. W., Low, G. S., \& Moncrief, W. C. (2001). The role of satisfaction with territory design on the motivation, attitudes, and work outcomes of salespeople. Journal of the Academy of Marketing Science, 29, 165-178.

Green, S. G., Anderson, S. E., \& Shivers, S. L. (1996). Demographic and organizational influences on leader-member exchange and related work attitudes. Organizational Behavior and Human Decision Processes, 62, 203-214.

Green, S. G., Blank, W., \& Liden, R. C. (1983). Market and organizational influences on bank employees' work attitudes and behaviors. Journal of Applied Psychology, 68, 298-306. 
Greenberger, E., Goldberg, W. A., Hamill, S., O’Neill, R., \& Payne, C. K. (1989). Contributions of a supportive environment to parents' well-being and orientation to work. American Journal of Community Psychology, 17, 755-783.

Greenberger, E., \& O'Neil, R. (1993). Spouse, parent, worker: Role commitments and role-related experiences in the construction of adults' well-being. Developmental Psychology, 29, 181-197.

Gregersen, H. B., \& Black, J. S. (1990). A multifaceted approach to expatriate retention in international assignments. Group and Organization Studies, 15, 461-485.

Griffeth, R. W., Hom, P. W., DeNisi, A. S., \& Kirchner, W. K. (1985). A comparison of different methods of clustering countries on the basis of employee attitudes. Human Relations, 38, 813-840.

Grover, S. L. (1992). The effect of increasing education on individual professional behavior and commitment. Journal of Vocational Behavior, 40, 1-13.

Grover, S. L., \& Crooker, K. J. (1995). Who appreciates family-responsive human resource policies: The impact of family-friendly policies on the organizational attachment of parents and non-parents. Personnel Psychology, 48, 271-288.

Grube, J. A., \& Piliavin, J. A. (2000). Role identity, organizational experiences, and volunteer performance. Personality and Social Psychology Bulletin, 26, 1108-1119.

Grusky, O. (1965). Career mobility and organizational commitment. Administrative Science Quarterly, 10, 488-503.

Guimond, S. (1995). Encounter and metamorphosis: The impact of military socialisation on professional values. Applied Psychology: An International Review, 44, 251-275.

Gunz, H. P., \& Gunz, S. P. (1994). Professional/organizational commitment and job satisfaction for employed lawyers. Human Relations, 47, 801-828.

Gutek, B. A., Cohen, A. G., \& Tsui, A. (1996). Reactions to perceived sex discrimination. Human Relations, 49, 791-813.

Guzzo, R. A., Noonan, K. A., \& Elron, E. (1994). Expatriate managers and the psychological contract. Journal of Applied Psychology, 79, 617-626.

Hackett, R. D., Bycio, P., \& Hausdorf, P. A. (1994). Further assessments of Meyer and Allen's (1991) three-component model of organizational commitment. Journal of Applied Psychology, 79, 15-23. 
Hackett, R. D., Lapierre, L. M., \& Hausdorf, P. A. (2001). Understanding the links between work commitment constructs. Journal of Vocational Behavior, 58, 392413.

Hackman, J. R., \& Lawler, E. E., III. (1971). Employee reactions to job characteristics. Journal of Applied Psychology, 55, 259-286.

Hall, D. T., Goodale, J. G., Rabinowitz, S., \& Morgan, M. A. (1978). Effects of top-down departmental and job change upon perceived employee behavior and attitudes: A natural field experiment. Journal of Applied Psychology, 63, 62-72.

Hammer, T. H., Landau, J. C., \& Stern, R. N. (1981). Absenteeism when workers have a voice: The case of employee ownership. Journal of Applied Psychology, 66, 561 573.

Hanlon, M. D. (1986). Age and commitment to work: A literature review and multivariate analysis. Research on Aging, 8, 289-316.

Harris, S. G., Hirschfeld, R. R., Feild, H. S., \& Mossholder, K. W. (1993). Psychological attachment: Relationships with job characteristics, attitudes, and preferences for newcomer development. Group and Organization Management, 18, 459-481.

Harris, S. G., \& Mossholder, K. W. (1996). The affective implications of perceived congruence with culture dimensions during organizational transformation. Journal of Management, 22, 527-547.

Harrison, J. K., \& Hubbard, R. (1998). Antecedents to organizational commitment among Mexican employees of a U.S. firm in Mexico. Journal of Social Psychology, 138, 609-623.

Heaven, P. C. L. (1994). Occupational attributional style and attitudes to work: An Australian study. Australian Psychologist, 29, 57-61.

Hendrix, W. H., Robbins, T., Miller, J., \& Summers, T. P. (1998). Effects of procedural and distributive justice on factors predictive of turnover. Journal of Social Behavior and Personality, 13, 611-632.

Hendrix, W. H., \& Spencer, B. A. (1989). Development and test of a multivariate model of absenteeism. Psychological Reports, 64, 923-938.

Hendrix, W. H., \& Taylor, G. S. (1987). A multivariate analysis of the relationship between cigarette smoking and absence from work. American Journal of Health Promotion, 2, 5-11. 
Herndon, Jr., N. C., Fraedrich, J. P., \& Yeh, Q. (2001). An investigation of moral values and the ethical content of the corporate culture: Taiwanese versus U.S. sales people. Journal of Business Ethics, 30, 73-85.

Heshizer, B. P., Martin, H. J., \& Wiener, Y. (1991). Normative commitment and instrumental attachment as intervening variables in the prediction of union participation. Journal of Applied Behavioral Science, 27, 532-549.

Higgins, C. A., Duxbury, L. E., \& Irving, R. H. (1992). Work-family conflict in the dual-career family. Organizational Behavior and Human Decision Processes, 51, 5175.

Hirschfeld, R. R. (2000). Does revisiting the intrinsic and extrinsic subscales of the Minnesota Satisfaction Questionnaire short form make a difference? Educational and Psychological Measurement, 60, 255-270.

Hirschfeld, R. R., \& Feild, H. S. (2000). Work centrality and work alienation: Distinct aspects of a general commitment to work. Journal of Organizational Behavior, 21, 789-800.

Hirschfeld, R. R, Feild, H.S., \& Bedeian, A. G. (2000). Work alienation as an individual-difference construct for predicting workplace adjustment: $A$ test in two samples. Journal of Applied Social Psychology, 30, 1880-1902.

Ho, R., \& Lloyd, J. I. (1984). Development of an Australian work ethic scale. Australian Psychologist, 19, 321-332.

Hochwarter, W. A., Perrewe, P. L., Ferris, G. R., \& Guercio, R. (1999). Commitment as an antidote to the tension and turnover consequences of organizational politics. Journal of Vocational Behavior, 55, 277-297.

Hoff, T. J. (1998). Physician executives in managed care: Characteristics and job involvement across two career stages. Journal of Healthcare Management, 43, 481-497.

Hoff, T. J. (2000). Professional commitment among US physician executives in managed care. Social Science and Medicine, 50, 1433-1444.

Hollenbeck, J. R. (1989). Control theory and the perception of work environments: The effects of focus of attention on affective and behavioral reactions to work. Organizational Behavior and Human Decision Processes, 43, 406-430.

Hollenbeck, J. R., \& Williams, C. R. (1986). Turnover functionality versus turnover frequency: A note on work attitudes and organizational effectiveness. Journal of Applied Psychology, 71, 606-611. 
Hollon, C. J. (1983). Machiavellianism and managerial work attitudes and perceptions. Psychological Reports, 52, 432-434.

Holton, E. F., III, \& Russell, C. J. (1997). The relationship of anticipation to newcomer socialization processes and outcomes: A pilot study. Journal of Occupational and Organizational Psychology, 70, 163-172.

Holton, E.F., III, \& Russell, C. J. (1999). Organizational entry and exit: An exploratory longitudinal examination of early careers. Human Performance, 12, 311-341.

Hom, P. W., Griffeth, R. W., Palich, L. E., \& Bracker, J. S. (1998). An exploratory investigation into theoretical mechanisms underlying realistic job previews. Personnel Psychology, 51, 421-451.

Hom, P. W., \& Hulin, C. L. (1981). A competitive test of the prediction of reenlistment by several models. Journal of Applied Psychology, 66, 23-39.

Hom, P. W., Katerberg, R., Jr., \& Hulin, C. L. (1979). Comparative examination of three approaches to the prediction of turnover. Journal of Applied Psychology, 64, 280-290.

Howard, L. W. (1999). Validity evidence for measures of procedural/distributive justice and pay/benefit satisfaction. Journal of Business and Psychology, 14, 135-147.

Howell, J. P., \& Dorfman, P. W. (1981). Substitutes for leadership: Test of a construct. Academy of Management Journal, 24, 714-728.

Howell, J. P., \& Dorfman, P. W. (1986). Leadership and substitutes for leadership among professional and nonprofessional workers. Journal of Applied Behavioral Science, $\underline{22}, 29-46$.

Huselid, M. A., \& Day, N. E. (1991). Organizational commitment, job involvement, and turnover: A substantive and methodological analysis. Journal of Applied Psychology, 76, 380-391.

Igbaria, M., \& Greenhaus, J. H. (1992). The career advancement prospects of managers and professionals: Are MIS employees unique? Decision Sciences, 23, 478-499.

Igbaria, M., Meredith, G., \& Smith, D. C. (1994). Predictors of intention of IS professionals to stay with the organization in South Africa. Information and Management, $26,245-256$.

Igbaria, M., \& Siegel, S. R. (1992). The reasons for turnover of information systems personnel. Information and Management. 23, 321-330. 
Igbaria, M., \& Wormley, W. M. (1992). Organizational experiences and career success of MIS professionals and managers: An examination of race differences. MIS Quarterly, 16, 507-529.

Indiresan, J. (1975). Multivariate analysis of factors affecting the job satisfaction of engineering teachers. Indian Journal of Psychometry and Education, 6, 16-27.

Indiresan, J. (1981). Job satisfaction of engineering teachers: A cross-cultural study. Indian Journal of Applied Psychology, 18, 16-26.

Irving, P. G., Coleman, D. F., \& Cooper, C. L. (1997). Further assessments of a three-component model of occupational commitment: Generalizability and differences across occupations. Journal of Applied Psychology, 82, 444-452.

Irving, P. G., \& Meyer, J. P. (1994). Reexamination of the met-expectations hypothesis: A longitudinal analysis. Journal of Applied Psychology, 79, 937-949.

Ivancevich, J. M. (1980). A longitudinal study of behavioral expectation scales: Attitudes and performance. Journal of Applied Psychology, 65, 139-146.

Ivancevich, J. M. (1985). Predicting absenteeism from prior absence and work attitudes. Academy of Management Journal, 28, 219-228.

Ivancevich, J. M., \& McMahon, J. T. (1982). The effects of goal setting, external feedback, and self-generated feedback on outcome variables: A field experiment. Academy of Management Journal, 25, 359-372.

Iverson, R. D. (2000). An event history analysis of employee turnover: The cause of hospital employees in Australia. Human Resource Management Review, 9, 397-418.

Iverson, R. D., \& Buttigieg, D. M. (1997). Antecedents of union commitment: The impact of union membership differences in vertical dyads and work group relationships. Human Relations, 50, 1485-1510.

Iverson, R. D., \& Buttigieg, D. M. (1999). Affective, normative and continuance commitment: Can the 'right kind' of commitment be managed? Journal of Management Studies, 36, 307-333.

Iverson, R. D., \& Kuruvilla, S. (1995). Antecedents of union loyalty: The influence of individual dispositions and organizational context. Journal of Organizational Behavior, 16, 557-582. 
Iverson, R. D., \& Roy, P. (1994). A causal model of behavioral commitment: Evidence from a study of Australian blue-collar employees. Journal of Management, 20, $15-41$.

Jalajas, D. S., \& Bommer, M. (1999). A comparison of the impact of past and the threat of future downsizings on workers. Journal of Social Behavior and Personality, 14, 89-100.

Jamal, M. (1981). Shift work related to job attitudes, social participation and withdrawal behavior: A study of nurses and industrial workers. Personnel Psychology, 34, 535-547.

Jamal, M. (1984). Job stress and job performance controversy: An empirical assessment. Organizational Behavior and Human Performance, 33, 1-21.

Jamal, M. (1986). Moonlighting: Personal, social, and organizational consequences. Human Relations, 39, 977-990.

Jamal, M. (1990). Relationship of job stress and Type-A behavior to employees' job satisfaction, organizational commitment, psychosomatic health problems, and turnover motivation. Human Relations, 43, 727-738.

Jamal, M. (1999). Job stress and employee well-being: A cross-cultural empirical study. Stress Medicine, 15, 153-158.

Jamal, M., \& Baba, V. V. (1991). Type A behavior, its prevalence and consequences among women nurses: An empirical examination. Human Relations, 44, 1213-1228.

Jamal, M., \& Baba, V. V. (1992). Shiftwork and department-type related to job stress, work attitudes and behavioral intentions: A study of nurses. Journal of Organizational Behavior, 13, 449-464.

Jamal, M., \& Baba, V. V. (2000). Job stress and burnout among Canadian managers and nurses: An empirical investigation. Canadian Journal of Public Health, 91, 454-458.

Jamal, M., Baba, V. V., \& Riviere, R. (1998). Job stress and well-being of moonlighters: The perspective of deprivation or aspiration revisited. Stress Medicine, 14 , 195-202.

Jamal, M., \& Badawi, J. A. (1995). Nonstandard work schedules and work and nonwork experiences of Muslim immigrants: A study of a minority in the majority. Journal of Social Behavior and Personality, 10, 395-408. 
James, L. R., \& Jones, A. P. (1980). Perceived job characteristics and job satisfaction: An examination of reciprocal causation. Personnel Psychology, 33, 97-135.

Jans, N. A. (1989). Organizational commitment, career factors and career/life stage. Journal of Organizational Behavior, 10, 247-266.

Jaros, S. J. (1997). An assessment of Meyer and Allen's (1991) three-component model of organizational commitment and turnover intentions. Journal of Vocational Behavior, 51, 319-337.

Jaros, S. J., Jermier, J. M., Koehler, J. W., \& Sincich, T. (1993). Effects of continuance, affective, and moral commitment on the withdrawal process: An evaluation of eight structural equation models. Academy of Management Journal, 36, 951-995.

Jauch, L. R., Glueck, W. F., \& Osborn, R. N. (1978). Organizational loyalty, professional commitment, and academic research productivity. Academy of Management Journal, 21, 84-92.

Jenkins, J. M. (1993). Self-monitoring and turnover: The impact of personality on intent to leave. Journal of Organizational Behavior, 14, 83-91.

Jenkins, S. R., \& Maslach, C. (1994). Psychological health and involvement in interpersonally demanding occupations: A longitudinal perspective. Journal of Organizational Behavior, 15, 101-127.

Jenner, J. R. (1981). Volunteerism as an aspect of women's work lives. Journal of Vocational Behavior, 19, 302-314.

Jenner, J. R. (1984). Organizational commitment among women volunteers: Meaning and measurement. Psychological Reports, 54, 991-996.

Jermier, J. M., \& Berkes, L. J. (1979). Leader behavior in a police command bureaucracy: A closer look at the quasi-military model. Administrative Science Quarterly, $\underline{24}, 1-23$.

Jex, S. M., \& Bliese, P. D. (1999). Efficacy beliefs as a moderator of the impact of work-related stressors: A multilevel study. Journal of Applied Psychology, 84, 349361.

Johlke, M. C., Duhan, D. F., Howell, R. D., \& Wilkes, R. W. (2000). An integrated model of sales managers' communication practices. Journal of the Academy of Marketing Science, 28, 263-277. 
Johnson, G. J., \& Johnson, W. R. (1995). The effects of union membership on multiple work commitments among female public sector employees. Journal of Psychology, 129, 181-191.

Johnson, W. R. (1992). The impact of quality circle participation on job satisfaction and organizational commitment. Psychology, 29, 1-11.

Johnson, W. R. (1992). Public and private sector comparison of an abbreviated measure of union commitment. Journal of Collective Negotiations, 21, 15-26.

Johnson, W. R., \& Jones-Johnson, G. (1992). Differential predictors of union and company commitment: Parallel and divergent models. Psychology, 29, 1-12.

Johnston, G. P., III., \& Snizek, W. E. (1991). Combining head and heart in complex organizations: A test of Etzioni's dual compliance structure hypothesis. Human Relations, 44, 1255-1272.

Johnston, M. W., Parasuraman, A., Futrell, C. M., \& Black, W. C. (1990). A longitudinal assessment of the impact of selected organizational influences on salespeople's organizational commitment during early employment. Journal of Marketing Research, 27, 333-344.

Jones, A. P. (1984). Organizational reward systems: Implications for climate. Motivation and Emotion, 8, 259-274.

Jones, A. P., \& Butler, M. C. (1980). A role transition approach to the stresses of organizationally induced family role disruption. Journal of Marriage and the Family, 42, 367-376.

Jones, A. P., Glaman, J. M., \& Johnson, D. S. (1993). Perceptions of a quality program and relationships with work perceptions and job attitudes. Psychological Reports, 72, 619-624.

Jones, G. R. (1986). Socialization tactics, self-efficacy, and newcomers' adjustments to organizations. Academy of Management Journal, 29, 262-279.

Jorde-Bloom, P. (1988). Factors influencing overall job satisfaction and organizational commitment in early childhood work environments. Journal of Research in Childhood Education, 3, 107-122.

Joshi, G. (1999). Job satisfaction, job and work involvement among the industrial employees: A correlational study. Journal of the Indian Academy of Applied Psychology, 25, 79-82. 
Joyce, W. F. (1986). Matrix organization: A social experiment. Academy of Management Journal, 29, 536-561.

Judge, T. A., Thoresen, C. J., Pucik, V., \& Welbourne, T. M. (1999). Managerial coping with organizational change: A dispositional perspective. Journal of Applied Psychology, 84, 107-122.

Kacmar, K.M., Carlson, D. S., \& Brymer, R. A. (1999). Antecedents and consequences of organizational commitment: A comparison of two scales. Educational and Psychological Measurement, 59, 976-994.

Kadishi-Fassler, B. (1996). The influence of personal values on organizational commitment. Swiss Journal of Psychology, 54, 186-199.

Kahn, S. E., Long, B. C., \& Peterson, C. (1989). Marital and parental status and quality of life of female clerical workers. Canadian Journal of Counselling, 23, 174-183.

Kaldenberg, D. O., Becker, B. W., \& Zvonkovic, A. (1995). Work and commitment among young professionals: A study of male and female dentists. Human Relations, 48, 1355-1377.

Kalliath, T. J., Bluedorn, A. C., \& Strube, M. J. (1999). A test of value congruence effects. Journal of Organizational Behavior, 20, 1175-1198.

Kanungo, R. N. (1982). Measurement of job and work involvement. Journal of Applied Psychology, 67, 341-349.

Karambayya, R., \& Reilly, A. H. (1992). Dual earner couples: Attitudes and actions in restructuring work for family. Journal of Organizational Behavior, 13, 585-601.

Keashly, L., Hunter, S., \& Harvey, S. (1997). Abusive interaction and role state stressors: Relative impact on student residence assistant stress and work attitudes. Work and Stress, 11, 175-185.

Keller, R. T. (1997). Job involvement and organizational commitment as longitudinal predictors of job performance: A study of scientists and engineers. Journal of Applied Psychology, 82, 539-545.

Kelloway, E. K., Catano, V. M., \& Carroll, A. E. (2000). Psychological involvement in the union. Canadian Journal of Behavioural Science, 32, 163-167.

Kelloway, E. K., Catano, V. M., \& Southwall, R. R. (1992). The construct validity of union commitment: Development and dimensionality of a shorter scale. Journal of Occupational and Organizational Psychology, 65, 197-211. 
Kemery, E. R. (1991). Affective disposition, role stress, and job withdrawal. Journal of Social Behavior and Personality, 6, 331-347.

Kemp, N. J., Wall, T. D., Clegg, C. W., \& Cordery, J. L. (1983). Autonomous work groups in a greenfield site: A comparative study. Journal of Occupational Psychology, 56, 271-288.

Kenis, I. (1979). Effects of budgetary goal characteristics on managerial attitudes and performance. Accounting Review, 54, 707-720.

Khaleque, A. (1992). Work values, attitudes and performance of industrial workers in Bangladesh. Social Indicators Research, 27Social Indicators Research, 27, 187-195.

Kidron, A. (1978). Work values and organizational commitment. Academy of Management Journal, 21, 239-247.

Kidwell, R. E., Jr., Mossholder, K. W., \& Bennett, N. (1997). Cohesiveness and organizational citizenship behavior: A multilevel analysis using work groups and individuals. Journal of Management, 23, 775-793.

Kim, S. (1999). Behavioral commitment among the automobile workers in South Korea. Human Resource Management Review, 9, 419-451.

Kim, S., Price, J. L., Mueller, C. W., \& Watson, T. W. (1996). The determinants of career intent among physicians at a U.S. Air Force hospital. Human Relations, 49, $947-$ 976.

Kim, W. C., \& Mauborgne, R. A. (1993). Procedural justice, attitudes, and subsidiary top management compliance with multinationals' corporate strategic decisions. Academy of Management Journal, 36, 502-526.

Kimmons, G., \& Greenhaus, J. H. (1976). Relationship between locus of control and reactions of employees to work characteristics. Psychological Reports, 39, 815-820.

King, R. C., \& Sethi, V. (1997). The moderating effect of organizational commitment on burnout in information systems professionals. European Journal of Information Systems, 6, 86-96.

Kirchmeyer, C. (1992). Nonwork participation and work attitudes: A test of scarcity vs. expansion models of personal resources. Human Relations, 45, 775-795. 
Kirchmeyer, C. (1995). Demographic similarity to the work group: A longitudinal study of managers at the early career stage. Journal of Organizational Behavior, 16, 6783.

Kirchmeyer, C., \& Bullin, C. (1997). Gender roles in a traditionally female occupation: A study of emergency, operating, intensive care, and psychiatric nurses. Journal of Vocational Behavior, 50, 78-95.

Kirkman, B. L., \& Shapiro, D. L. (2001). The impact of cultural values on job satisfaction and organizational commitment in self-managing work teams: The mediating role of employee resistance. Academy of Management Journal, 44, 557-569.

Kirmeyer, S. L., \& Biggers, K. (1988). Environmental demand and demand engendering behavior: An observational analysis of the Type A pattern. Journal of Personality and Social Psychology, 54, 997-1005.

Kivimaki, M., \& Kalimo, R. (1993). Risk perception among nuclear power plant personnel: A survey. Risk Analysis, 13, 421-424.

Kivimaki, M., Kalimo, R., \& Salminen, S. (1995). Perceived nuclear risk, organizational commitment, and appraisals of management: A study of nuclear power plant personnel. Risk Analysis, 15, 391-396.

Klaas, B. S., \& McClendon, J. A. (1995). Crossing the line: The determinants of picket line crossing during a faculty strike. Journal of Labor Research, 16, 311-346.

Klandermans, B. (1989). Union commitment: Replications and tests in the Dutch context. Journal of Applied Psychology, 74, 869-875.

Klein, D. J., \& Verbeke, W. (1999). Autonomic feedback in stressful environments: How do individual differences in autonomic feedback relate to burnout, job performance, and job attitudes in salespeople? Journal of Applied Psychology, 84, 911924.

Klein, H. J. (1988). Job satisfaction in professional dual-career couples: Psychological and socioeconomic variables. Journal of Vocational Behavior, 32, 255-268.

Klein, H. J., \& Weaver, N. A. (2000). The effectiveness of an organizational-level orientation training program in the socialization of new hires. Personnel Psychology, 53, 47-66.

Knoop, R. (1986). Job involvement: An elusive concept. Psychological Reports, 59, 451-456. 
Knoop, R. (1995). Influence of participative decision-making on job satisfaction and organizational commitment of school principals. Psychological Reports. 76, 379-382.

Knoop, R. (1995). Relationships among job involvement, job satisfaction, and organizational commitment for nurses. Journal of Psychology, 129, 643-649.

Koberg, C. S., Boss, R. W., \& Goodman, E. (1998). Factors and outcomes associated with mentoring among health-care professionals. Journal of Vocational Behavior, 53, 58-72.

Koberg, C. S., \& Chusmir, L. H. (1987). Organizational culture relationships with creativity and other job-related variables. Journal of Business Research, 15, 397-409.

Koberg, C. S., \& Chusmir, L. H. (1989). Relationship between sex role conflict and work-related variables: Gender and hierarchical differences. Journal of Social Psychology, 129, 779-791.

Koh, W. L., Steers, R. M., \& Terborg, J. R. (1995). The effects of transformational leadership on teacher attitudes and student performance in Singapore. Journal of Organizational Behavior, 16, 319-333.

Koh. W. L., \& Yer, L. K. (2000). The impact of the employee-organization relationship on temporary employees' performance and attitude: Testing a Singaporean sample. International Journal of Human Resource Management, 11, 366-387.

Konczak, L. J., Stelly, D. J., \& Trusty, M. L. (2000). Defining and measuring empowering leader behaviors: Development of an upward feedback instrument. Educational and Psychological Measurement, 60, 301-313.

Kong, S. X., Wertheimer, A. I., Serradell, J., \& McGhan, W. F. (1994). Psychometric evaluation of measures of organizational commitment and intention to quit among pharmaceutical scientists. Pharmaceutical Research, 11, 171-180.

Konovsky, M. A., \& Cropanzano, R. (1991). Perceived fairness of employee drug testing as a predictor of employee attitudes and job performance. Journal of Applied Psychology, 76, 698-707.

Konovsky, M. A., Folger, R., \& Cropanzano, R. (1987). Relative effects of procedural and distributive justice on employee attitudes. Representative Research in Social Psychology, 17, 15-24.

Kontos, S., \& File, N. (1992). Conditions of employment, job satisfaction, and job commitment among early intervention personnel. Journal of Early Intervention, 16, 155165. 
Kopelman, R. E., Rovenpor, J. L., \& Millsap, R. E. (1992). Rationale and construct validity evidence for the Job Search Behavior Index: Because intentions (and New Year's resolutions) often come to naught. Journal of Vocational Behavior, 40, 269287.

Koslowsky, M. (1991). A longitudinal analysis of job satisfaction, commitment, and intention to leave. Applied Psychology: An International Review, 40, 405-415.

Koslowsky, M., Caspy, T., \& Lazar, M. (1990). An empirical comparison of commitment scales. Journal of Applied Social Psychology, 20, 1063-1075.

Koslowsky, M., Caspy, T., \& Lazar, M. (1991). Cause and effect explanations of job satisfaction and commitment: The case of exchange commitment. Journal of Psychology, 125, 153-162.

Koslowsky, M., \& Krausz, M. (1994). On the relationship between commuting, stress symptoms, and attitudinal measures: A LISREL application. Journal of Applied Behavioral Science, 29, 485-492.

Koys, D. J. (1991). Fairness, legal compliance, and organizational commitment. Employee Responsibilities and Rights Journal, 4, 283-291.

Krausz, M., Brandwein, T., \& Fox, S. (1995). Work attitudes and emotional responses of permanent, voluntary, and involuntary temporary-help employees: An exploratory study. Applied Psychology: An International Review, 44, 217-232.

Krausz, M., Sagie, A., \& Bidermann, Y. (2000). Actual and preferred work schedules and scheduling control as determinants of job-related attitudes. Journal of Vocational Behavior, 56, 1-11.

Kroposki, M., Murdaugh, C. L., Tavakoli, A. S., \& Parsons, M. (1999). Role clarity, organizational commitment, and job satisfaction during hospital reengineering. Nursing Connections, 12, 27-34.

Kubes, M. (1990). Discriminant validity of three measures of work attitudes. Studia Psychologica, 32, 149-152.

Kudisch, J. D., Poteet, M. L., Dobbins, G. H., Rush, M. C., \& Russell, J. E. A. (1995). Expert power, referent power, and charisma: Toward the resolution of a theoretical debate. Journal of Business and Psychology, 10, 177-195.

Kumar, K. G., \& Achamamba, B. (1993). A comparative study of job satisfaction and job involvement among public and private sector employees. Psychological Studies, 38, 69-72. 
Kushnir, T., Melamed, S., \& Ribak, J. (1997). Occupational physicians in Israel: Work structure, job and personal characteristics, and job satisfaction. Journal of Occupational and Environmental Medicine, 39, 874-881.

Lachman, R., \& Aranya, N. (1986). Evaluation of alternative models of commitments and job attitudes of professionals. Journal of Occupational Behaviour, 7 , 227-243.

Lachman, R., \& Aranya, N. (1986). Job attitudes and turnover intentions among professionals in different work settings. Organization Studies, 7, 279-293.

Lachman, R., \& Noy, S. (1997). Salaried physicians' intent to retain hospital membership: The effects of position and work attitudes. Hospital and Health Services Administration, 42, 509-524.

Laczo, R. M., \& Hanisch, K. A. (2000). An examination of behavioral families of organizational withdrawal in volunteer workers and paid employees. Human Resource Management Review, 9, 453-477.

Lam, P., Foong, Y. Y., \& Moo, S. N. (1995). Work life, career commitment, and job satisfaction as antecedents of career withdrawal cognition among teacher interns. Journal of Research and Development in Education, 28, 230-236.

Lance, C. E. (1991). Evaluation of a structural model relating job satisfaction, organizational commitment, and precursors to voluntary turnover. Multivariate Behavioral Research, 26, 137-162.

Lance, C. E., \& Richardson, D. R. (1988). Correlates of work and non-work stress and satisfaction among American insulated sojourners. Human Relations, 41, 725738.

Landau, J., \& Hammer, T. H. (1986). Clerical employees' perceptions of intraorganizational career opportunities. Academy of Management Journal, 29, 385-404.

Landsbergis, P. A., Schnall, P. L., Deitz, D., Friedman, R., \& Pickering, T. (1992). The patterning of psychological attributes and distress by "job strain" and social support in a sample of working men. Journal of Behavioral Medicine, 15, 379-405.

Larson, E. W., \& Fukami, C. V. (1984). Relationships between worker behavior and commitment to the organization and union. Academy of Management Best Paper Proceedings, 222-226. 
Laschinger, H. K. S., Finegan, J., Shamian, J., \& Casier, S. (2000).

Organizational trust and empowerment in restructured healthcare settings: Effects on staff nurse commitment. Journal of Nursing Administration, 30, 413-425.

Latham, V. M., \& Leddy, P. M. (1987). Source of recruitment and employee attitudes: An analysis of job involvement, organizational commitment, and job satisfaction. Journal of Business and Psychology, 1, 230-235.

Lawler, E. E., III., \& Hall, D. T. (1970). Relationship of job characteristics to job involvement, satisfaction, and intrinsic motivation. Journal of Applied Psychology, 54, 305-312.

Lawson, M. B., \& Angle, H. L. (1998). Upon reflection: Commitment, satisfaction, and regret after a corporate relocation. Group and Organization Management, 23, 289-317.

Leck, J.D., \& Saunders, D.M. (1992). Hirschman's loyalty: Attitude or behavior? Employee Responsibilities and Rights Journal, 5, 219-230.

Lee, R., \& Graham, W. K. (1986). Self-actualization need strength: Moderator of relationships between job characteristics and job outcomes. Journal of Employment Counseling, 23, 38-47.

Lee, R. T., \& Ashforth, B. E. (1993). A further examination of managerial burnout: Toward an integrated model. Journal of Organizational Behavior, 14, 3-20.

Lee, T. W. (1988). How job dissatisfaction leads to employee turnover. Journal of Business and Psychology, 2, 263-271.

Lee, T. W., Ashford, S. J., Walsh, J. P., \& Mowday, R. T. (1992). Commitment propensity, organizational commitment, and voluntary turnover: A longitudinal study of organizational entry processes. Journal of Management, 18, 15-32.

Lee, T. W., \& Johnson, D. R. (1991). The effects of work schedule and employment status on the organizational commitment and job satisfaction of full versus part time employees. Journal of Vocational Behavior, 38, 208-224.

Lee, T. W., \& Maurer, S. D. (1999). The effects of family structure on organizational commitment, intention to leave and voluntary turnover. Journal of Managerial Issues, 11, 493-513.

Lee, T. W., \& Mowday, R. T. (1987). Voluntarily leaving an organization: An empirical investigation of Steers and Mowday's model of turnover. Academy of Management Journal, 30, 721-743. 
Lehman, W. E. K., \& Simpson, D. D. (1992). Employee substance use and onthe-job behaviors. Journal of Applied Psychology, 77, 309-321.

Leong, C. S., Furnham, A., \& Cooper, C. L. (1996). The moderating effect of organizational commitment on the occupational stress outcome relationship. Human Relations, 49, 1345-1363.

Leung, K. (1997). Relationships among satisfaction, commitment, and performance: A group-level analysis. Applied Psychology: An International Review, 46, 199-205.

Levy, P. E., \& Williams, J. R. (1998). The role of perceived system knowledge in predicting appraisal reactions, job satisfaction, and organizational commitment. Journal of Organizational Behavior, 19, 53-65.

Liden, R. C., Wayne, S. J., \& Sparrowe, R. T. (2000). An examination of the mediating role of psychological empowerment on the relations between the job, interpersonal relationships, and work outcomes. Journal of Applied Psychology, 85, 407416.

Lim, V. K. G., \& Yuen, E. C. (1998). Doctors, patients, and perceived job image: An empirical study of stress and nurses in Singapore. Journal of Behavioral Medicine, 21, 269-282.

Lincoln, J. R., \& Boothe, J. N. (1993). Unions and work attitudes in the United States and Japan. Industrial Relations, 32, 159-187.

Lincoln, J. R., \& Kalleberg, A. L. (1985). Work organization and workforce commitment: A study of plants and employees in the U.S. and Japan. American Sociological Review, 50, 738-760.

Littrell, P.G., Billingsley, B. S., \& Cross, L. H. (1994). The effects of principal support on special and general educators' stress, job satisfaction, school commitment, health, and intent to stay in teaching. Remedial and Special Education, 15, 297-310.

Livingstone, L. P., Nelson, D. L., \& Barr, S. H. (1997). Person-environment fit and creativity: An examination of supply-value and demand-ability versions of fit. Journal of Management, 23, 119-146.

Lodahl, T. M., \& Kejner, M. (1965). The definition and measurement of job involvement. Journal of Applied Psychology, 49, 24-33. 
Lord, A. T., \& DeZoort, F. T. (2001). The impact of commitment and moral reasoning on auditors' responses to social influence pressure. Accounting. Organizations and Society, 26, 215-235.

Lounsbury, J. W., \& Hoopes, L. L. (1986). A vacation from work: Changes in work and nonwork outcomes. Journal of Applied Psychology, 71, 392-401.

Lowe, R. H., \& Vodanovich, S. J. (1995). A field study of distributive and procedural justice as predictors of satisfaction and organizational commitment. Journal of Business and Psychology, 10, 99-114.

Lum, L., Kervin, J., Clark, K., Reid, F., \& Sirola, W. (1998). Explaining nursing turnover intent: Job satisfaction, pay satisfaction, or organizational commitment? Journal of Organizational Behavior, 19, 305-320.

Luthans, B. C., \& Sommer, S. M. (1999). The impact of downsizing on workplace attitudes: Differing reactions of managers and staff in a health care organization. Group and Organization Management, 24, 46-70.

Luthans, F., Baack, D., \& Taylor, L. (1987). Organizational commitment: Analysis of antecedents. Human Relations, 40, 219-236.

Luthans, F., Wahl, L. K., \& Steinhaus, C. S. (1992). The importance of social support for employee commitment: A quantitative and qualitative analysis of bank tellers. Organization Development Journal, 10, 1-10.

Mabey, C., Clark, T., \& Daniels, K. (1996). A six-year longitudinal study of graduate expectations: The implications for company recruitment and selection strategies. International Journal of Selection and Assessment, 4, 139-150.

MacKenzie, S. B., Podsakoff, P. M., \& Ahearne, M. (1998). Some possible antecedents and consequences of in-role and extra-role salesperson performance. Journal of Marketing, 62, 87-98.

Mael, F. A., \& Alderks, C. E. (1993). Leadership team cohesion and subordinate work unit morale and performance. Military Psychology, 5, 141-158.

Mael, F. A., \& Tetrick, L. E. (1992). Identifying organizational identification. Educational and Psychological Measurement, 52, 813-824.

Magazine, S. L., Williams, L. J., \& Williams, M. L. (1996). A confirmatory factor analysis examination of reverse coding effects in Meyer and Allen's Affective and Continuance Scales. Educational and Psychological Measurement, 56, 241-250. 
Magenau, J. M., Martin, J. E., \& Peterson, M. M. (1988). Dual and unilateral commitment among stewards and rank-and-file union members. Academy of Management Journal, 31, 359-376.

Major, D. A., Kozlowski, S. W. J., Chao, G. T., \& Gardner, P. D. (1995). A longitudinal investigation of newcomer expectations, early socialization outcomes, and the moderating effects of role development factors. Journal of Applied Psychology, 80, 418431.

Manlove, E. E., \& Guzell, J. R. (1997). Intention to leave, anticipated reasons for leaving, and 12-month turnover of child care center staff. Early Childhood Research Quarterly, 12, 145-167.

Mannheim, B., Baruch, Y., \& Tal, J. (1997). Alternative models for antecedents and outcomes of work centrality and job satisfaction of high-tech personnel. Human Relations, 50, 1537-1562.

Mannheim, B., \& Papo, E. (2000). Differences in organizational commitment and its correlates among professional and nonprofessional occupational welfare workers. Administration in Social Work, 23, 119-139.

Marsh, R. M., \& Mannari, H. (1977). Organizational commitment and turnover: A prediction study. Administrative Science Quarterly, 22, 57-75.

Martelli, T. A., Waters, L. K., \& Martelli, J. (1989). The Police Stress Survey: Reliability and relation to job satisfaction and organizational commitment. Psychological Reports, 64, 267-273.

Martin, C. L., \& Bennett, N. (1996). The role of justice judgments in explaining the relationship between job satisfaction and organizational commitment. Group and Organization Management, 21, 84-104.

Martin, J. E., \& Berthiaume, R. D. (1993). Stress and the union steward's role. Journal of Organizational Behavior, 14, 433-446.

Martin, J. E., Magenau, J. M., \& Peterson, M. F. (1982). Variables differentiating patterns of commitment among union stewards. Academy of Management Best Paper Proceedings, 302-306.

Martin, J. E., \& Peterson, M. M. (1987). Two-tier wage structures: Implications for equity theory. Academy of Management Journal, 30, 297-315.

Martin, J. E., \& Sinclair, R. R. (2001). A multiple motive perspective on strike propensities. Journal of Organizational Behavior, 22, 387-407. 
Martin, T. N., \& Hafer, J. C. (1995). The multiplicative interaction effects of job involvement and organizational commitment on the turnover intentions of full- and parttime employees. Journal of Vocational Behavior, 46, 310-331.

Martocchio, J. J. (1994). The effects of absence culture on individual absence. Human Relations, 47, 243-262.

Maslyn, J. M., \& Fedor, D. B. (1998). Perceptions of politics: Does measuring different foci matter? Journal of Applied Psychology, 84, 645-653.

Mathieu, J. E. (1988). A causal model of organizational commitment in a military training environment. Journal of Vocational Behavior, 32, 321-335.

Mathieu, J. E., \& Farr, J. L. (1991). Further evidence for the discriminant validity of measures of organizational commitment, job involvement, and job satisfaction. Journal of Applied Psychology, 76, 127-133.

Mathieu, J. E., \& Hamel, K. (1989). A causal model of the antecedents of organizational commitment among professionals and nonprofessionals. Journal of Vocational Behavior, 34, 299-317.

Mathieu, J. E., \& Kohler, S. S. (1990). A cross-level examination of group absence influences on individual absence. Journal of Applied Psychology, 75, 217-220.

Mathieu, J. E., \& Kohler, S. S. (1990). A test of the interactive effects of organizational commitment and job involvement on various types of absence. Journal of Vocational Behavior, 36, 33-44.

Mayer, R. C., \& Schoorman, F. D. (1992). Predicting participation and production outcomes through a two-dimensional model of organizational commitment. Academy of Management Journal, 35, 671-684.

Mayer, R. C., \& Schoorman, F. D. (1998). Differentiating antecedents of organizational commitment: A test of March and Simon's model. Journal of Organizational Behavior, 19, 15-28.

McCaul, H. S., Hinsz, V. B., \& McCaul, K. D. (1995). Assessing organizational commitment: An employee's global attitude toward the organization. Journal of Applied Behavioral Science, 31, 80-90.

McClendon, J. A., \& Klaas, B. (1993). Determinants of strike-related militancy: An analysis of a university faculty strike. Industrial and Labor Relations Review, 46, 560573. 
McCloskey, J. C., \& McCain, B. E. (1987). Satisfaction, commitment and professionalism of newly employed nurses. IMAGE: Journal of Nursing Scholarship, 19, 20-24.

McCloskey, J. C., \& McCain, B. (1988). Variables related to nurse performance. IMAGE: Journal of Nursing Scholarship, 22, 203-207.

McGee. G. W., \& Ford, R. C. (1987). Two (or more?) dimensions of organizational commitment: Reexamination of the affective and continuance commitment scales. Journal of Applied Psychology, 72, 638-642.

McElroy, J. C., Morrow, P. C., \& Crum, M. R. (1997). Organization and union commitment among railroad employees. Transportation Research Part E: Logistics and Transportation Review, 33, 211-221.

McElroy, J. C., Morrow, P. C., Power, M. L., \& Iqbal, Z. (1993). Commitment and insurance agents' job perceptions, attitudes, and performance. Journal of Risk and Insurance, $60,363-384$.

McElroy, J. C., Morrow, P. C., \& Wardlow, T. R. (1999). A career stage analysis of police officer work commitment. Journal of Criminal Justice, 27, 507-516.

McFarlin, D. B., \& Sweeney, P. D. (1992). Distributive and procedural justice as predictors of satisfaction with personal and organizational outcomes. Academy of Management Journal, 35, 626-637.

McGinnis, S. K., \& Morrow, P. C. (1990). Job attitudes among full- and part-time employees. Journal of Vocational Behavior, 36, 82-96.

McKelvey, B., \& Sekaran, U. (1977). Toward a career-based theory of job involvement: A study of scientists and engineers. Administrative Science Quarterly, 22, 281-305.

McNeilly, K. M., \& Russ, F. A. (1992). The moderating effect of sales force performance on relationships involving antecedents of turnover. Journal of Personal Selling and Sales Management, 12, 9-20.

McNeese-Smith, D. (1995). Job satisfaction, productivity, and organizational commitment: The result of leadership. Journal of Nursing Administration, 25, 17-26.

McNeese-Smith, D. (1996). Increasing employee productivity, job satisfaction, and organizational commitment. Hospital and Health Services Administration, 41, 160175 . 
McNeese-Smith, D. K. (1999). The relationship between managerial motivation, leadership, nurse outcomes and patient satisfaction. Journal of Organizational Behavior, 20, 243-259.

McShane, S. L. (1986). The multidimensionality of union participation. Journal of Occupational Psychology, 59, 177-187.

Meglino, B. M., Ravlin, E. C., \& Adkins, C. L. (1989). A work values approach to corporate culture: A field test of the value congruence process and its relationship to individual outcomes. Journal of Applied Psychology, 74, 424-432.

Mellor, S. (1990). The relationship between membership decline and union commitment: A field study of local unions in crisis. Journal of Applied Psychology, 75, 258-267.

Mellor, S. (1992). The influence of layoff severity on post layoff union commitment among survivors: The moderating effect of the perceived legitimacy of a layoff account. Personnel Psychology, 45, 579-600.

Mellor, S., Mathieu, J. E., Barnes-Farrell, J. L., \& Rogelberg, S. G. (2001). Employees' nonwork obligations and organizational commitments: A new way to look at the relationships. Human Resource Management, 40, 171-184.

Mellor, S., Mathieu, J. E., \& Swim, J. K. (1994). Cross-level analysis of the influence of local union structure on women's and men's union commitment. Journal of Applied Psychology, 79, 203-210.

Meyer, J. P., \& Allen, N. J. (1984). Testing the "side-bet theory" of organizational commitment: Some methodological considerations. Journal of Applied Psychology, 69, 372-378.

Meyer, J. P., \& Allen, N. J. (1987). A longitudinal analysis of the early development and consequences of organizational commitment. Canadian Journal of Behavioral Science, 19, 199-215.

Meyer, J. P., \& Allen, N. J. (1988). Links between work experiences and organizational commitment during the first year of employment: A longitudinal analysis. Journal of Occupational Psychology, 61, 195-209.

Meyer, J. P., Allen, N. J., \& Smith, C. A. (1993). Commitment to organizations and occupations: Extension and test of a three-component conceptualization. Journal of Applied Psychology, 78, 538-551. 
Meyer, J. P., Bobocel, D. R., \& Allen, N. J. (1991). Development of organizational commitment during the first year of employment: A longitudinal study of pre-and post-entry influences. Journal of Management, 17, 717-733.

Meyer, J. P., Irving, P. G., \& Allen, N. J. (1998). Examination of the combined effects of work values and early work experiences on organizational commitment. Journal of Organizational Behavior, 19, 29-52.

Meyer, J. P., Paunonen, S. V., Gellatly, I. R., Goffin, R. D., \& Jackson, D. N. (1989). Organizational commitment and job performance: It's the nature of the commitment that counts. Journal of Applied Psychology, 74, 152-156.

Meyer, J. P., \& Smith, C. A. (2000). HRM practices and organizational commitment: Test of a mediation model. Canadian Journal of Administrative Sciences, 17, 319-331.

Miceli, M. P., \& Mulvey, P. W. (2000). Consequences of satisfaction with pay systems: Two field studies. Industrial Relations, 39, 62-87.

Michaels, C. E., \& Spector, P. E. (1982). Causes of employee turnover: A test of the Mobley, Griffeth, Hand, and Meglino model. Journal of Applied Psychology, 67, 5359.

Michaels, R. E., \& Dixon, A. L. (1994). Sellers and buyers on the boundary: Potential moderators of role stress-job outcome relationships. Journal of the Academy of Marketing Science, 22, 62-73.

Miller, K. I., Ellis, B. H., Zook, E. G., \& Lyles, J. S. (1990). An integrated model of communication, stress, and burnout in the workplace. Communication Research, 17, 300-326.

Millward, L. J., \& Hopkins, L. J. (1998). Psychological contracts, organizational and job commitment. Journal of Applied Social Psychology, 28, 1530-1556.

Mishra, P. C. (1988). Role-overload as a moderator of the relationship between job-satisfaction and job-involvement. Indian Journal of Current Psychological Research. $\underline{3}, 109-114$.

Mishra, P. C., \& Srivastava, S. (1999). Mental health as a moderator variable of the organisational commitment and job-satisfaction relationship. Psychological Studies, 44, 55-58. 
Misra, S., Ghosh, R., \& Kanungo, R. N. (1990). Measurement of family involvement: A cross-national study of managers. Journal of Cross-Cultural Psychology, $\underline{21}, 232-248$.

Misra, S., \& Kalro, A. (1981). Job involvement of intrinsically and extrinsically motivated Indian managers: To each according to his need. Human Relations, 34, 419426.

Misra, S., Kanungo, R. N., von Rosenstiel, L., \& Stuhler, E. A. (1985). The motivational formulation of job and work involvement: A cross-national study. Human Relations, 38, 501-518.

Moore, H. A. (1985). Job satisfaction and women's spheres of work. Sex Roles, 13, 663-678.

Moorman, R.H., Niehoff, B.P., \& Organ, D.W. (1993). Treating employees fairly and organizational citizenship behavior: Sorting the effects of job satisfaction, organizational commitment, and procedural justice. Employee Responsibilities and Rights Journal, 6, 209-225.

Morris, J. H., \& Snyder, R. A. (1979). A second look at need for achievement and need for autonomy as moderators of role perception-outcome relationships. Journal of Applied Psychology, 64, 173-178.

Morrison, D. L., \& Savery, L. K. (1996). The role of worker and job characteristics on turnover intentions. The International Journal of Human Factors in Manufacturing, 6 , 263-279.

Morrison, E. W. (1994). Role definitions and organizational citizenship behavior: The importance of the employee's perspective. Academy of Management Journal, 37, 1543-1567.

Morrow, P. C., \& Crum, M. R. (1998). The effects of perceived and objective safety risk on employee outcomes. Journal of Vocational Behavior, 53, 300-313.

Morrow, P. C., \& Goetz, J. F., Jr. (1988). Professionalism as a form of work commitment. Journal of Vocational Behavior, 32, 92-111.

Morrow, P. C., \& McElroy, J. C. (1986). On assessing measures of work commitment. Journal of Occupational Behaviour, 7, 139-145.

Morrow, P. C., \& McElroy, J. C. (1987). Work commitment and job satisfaction over three career stages. Journal of Vocational Behavior, 30, 330-346. 
Morrow, P. C., McElroy, J. C., \& Elliott, S. M. (1994). The effect of preference for work status, schedule, and shift on work-related attitudes. Journal of Vocational Behavior, 45, 202-222.

Morrow, P. C., McElroy, J. C., \& Phillips, C. M. (1994). Sexual harassment behaviors and work related perceptions and attitudes. Journal of Vocational Behavior, 45 , 295-309.

Morrow, P. C., \& Wirth, R. E. (1989). Work commitment among salaried professionals. Journal of Vocational Behavior, 34, 40-56.

Mossholder, K. W., Bennett, N., Kemery, E. R., \& Wesolowski, M. A. (1998). Relationships between bases of power and work reactions: The mediational role of procedural justice. Journal of Management, 24, 533-552.

Mossholder, K. W., Bennett, N., \& Martin, C. L. (1998). A multilevel analysis of procedural justice context. Journal of Organizational Behavior, 19, 131-141.

Mossholder, K. W., Kemery, E. R., Harris, S. G., Armenakis, A. A., \& McGrath, R. (1994). Confounding constructs and levels of constructs in affectivity measurement: An empirical investigation. Educational and Psychological Measurement, 54, 336-349.

Mossholder, K. W., Settoon, R. P., Armenakis, A. A., \& Harris, S. G. (2000). Emotion during organizational transformations. Group and Organization Management, 25, 220-243.

Mowday, R. T., Koberg, C. S., \& McArthur, A. W. (1984). The psychology of the withdrawal process: A cross-validational test of Mobley's intermediate linkages model of turnover in two samples. Academy of Management Journal, 27, 79-94.

Mudrack, P. E. (1989). Job involvement and Machiavellianism: Obsessioncompulsion or detachment? Journal of Psychology, 123, 491-486.

Mudrack, P. E., \& Naughton, T. J. (2001). The assessment of workaholism as behavioral tendencies: Scale development and preliminary empirical testing. International Journal of Stress Management, 8, 93-111.

Mueller, C. W., Boyer, E. M., Price, J. L., \& Iverson, R. D. (1994). Employee attachment and noncoercive conditions of work: The case of dental hygienists. Work and Occupations, 21, 179-212.

Mueller, C. W., Wallace, J. E., \& Price, J. L. (1992). Employee commitment: Resolving some issues. Work and Occupations, 19, 211-236. 
Mukherjee, B. N. (1969). Interrelationships among measures of job satisfaction and job involvement. Indian Journal of Psychology, 46, 21-32.

Mulinge, M. M. (2001). Employer control of employees: Extending the LincolnKalleberg corporatist model of satisfaction and attachment. Human Relations, 54, 285318.

Munene, J. C., \& Azuka, E. (1991). Some positive outcomes of work participation in Nigeria: A replication. Journal of Psychology in Africa. 1, 1-14, 16.

Murrell, A. J., Frieze, I. H., \& Olson, J. E. (1996). Mobility strategies and career outcomes: A longitudinal study of MBAs. Journal of Vocational Behavior, 49, 324-335.

Murrell, A. J., \& Sprinkle, J. (1993). The impact of negative attitudes toward computers on employees' satisfaction and commitment within a small company. Computers in Human Behavior, 9, 57-63.

Naumann, E. (1993). Antecedents and consequences of satisfaction and commitment among expatriate managers. Group and Organization Management, 18, 153187.

Nelson, H. W., Pratt, C. C., Carpenter, C. E., \& Walter, K. L. (1995). Factors affecting volunteer long-term care ombudsman organizational commitment and burnout. Nonprofit and Voluntary Sector Quarterly, 24, 213-233.

Netemeyer, R. G., Burton, S., \& Johnston, M. W. (1995). A nested comparison of four models of the consequences of role perception variables. Organizational Behavior and Human Decision Processes, 61, 77-93.

Newman, J. E. (1975). Understanding the organizational structure: Job attitude relationship through perceptions of the work environment. Organizational Behavior and Human Performance, 14, 371-397.

Newman, J. M., \& Krzystofiak, F. J. (1993). Changes in employee attitudes after an acquisition: A longitudinal analysis. Group and Organization Management, 18, 390410 .

Ngo, H., \& Tsang, A. W. N. (1998). Employment practices and organizational commitment: Differential effects for men and women? The International Journal of Organizational Analysis, 6, 251-266.

Niehoff, B. P., Enz, C. A., \& Grover, R. A. (1990). The impact of topmanagement actions on employee attitudes and perceptions. Group and Organization Studies, 15, 337-352. 
Nkomo, S. M., \& Cox, Jr., T. (1989). Gender differences in the upward mobility of black managers: Double whammy or double advantage. Sex Roles, 21, 825-839.

Noe, R. A., \& Barber, A. E. (1993). Willingness to accept mobility opportunities: Destination makes a difference. Journal of Organizational Behavior, 14, 159-175.

Norris, D. R., \& Niebuhr, R. E. (1983). Professionalism, organizational commitment and job satisfaction in an accounting organization. Accounting, Organizations, and Society, 9, 49-59.

Nouri, H. (1994). Using organizational commitment and job involvement to predict budgetary slack: A research note. Accounting. Organizations, and Society, 19, 289-295.

Nouri, H., \& Parker, R. J. (1998). The relationship between budget participation and job performance: The roles of budget adequacy and organizational commitment. Accounting, Organizations and Society, 23, 467-483.

Nye, L. G., \& Witt, L. A. (1992). Dimensionality and construct validity of the Perceptions of Organizational Politics Scale (POPS). FAA Office of Aviation Medicine Reports, FAA-AM-92-10.

Nystedt, L., Sjoberg, A., \& Hagglund, G. (1999). Discriminant validation of measures of organizational commitment, job involvement, and job satisfaction among Swedish army officers. Scandinavian Journal of Psychology, 40, 49-55.

O'Driscoll, M. P., Ilgen, D. R., \& Hildreth, K. (1992). Time devoted to job and off-job activities, interrole conflict, and affective experiences. Journal of Applied Psychology, 77, 272-279.

O’Driscoll, M. P., \& Randall, D. M. (1999). Perceived organisational support, satisfaction with rewards, and employee job involvement and organisational commitment. Applied Psychology: An International Review, 48, 197-209.

O'Hara, K. B., Beehr, T. A., \& Colarelli, S. M. (1994). Organizational centrality: A third dimension of intraorganizational career movement. Journal of Applied Behavioral Science, 30, 198-216.

O'Neill, B. S., \& Mone, M. A. (1998). Investigating equity sensitivity as a moderator of relations between self-efficacy and workplace attitudes. Journal of Applied Psychology, 83, 805-816. 
O'Reilly, C., III., \& Chatman, J. (1986). Organizational commitment and psychological attachment: The effects of compliance, identification, and internalization on prosocial behavior. Journal of Applied Psychology, 71, 492-499.

O’Reilly, C. A., III, Bretton, G. E., \& Roberts, K. H. (1974). Professional employees' preference for upward mobility: An extension. Journal of Vocational Behavior, 5, 139-145.

O'Reilly, C. A., III., \& Caldwell, D. F. (1981). The commitment and job tenure of new employees: Some evidence of postdecisional justification. Administrative Science Quarterly, 26, 597-616.

O'Reilly, C. A., III., Chatman, J., \& Caldwell, D. F. (1991). People and organizational culture: A profile comparison approach to assessing person-organization fit. Academy of Management Journal, 34, 487-516.

O'Reilly, C. A., III., \& Roberts, K. H. (1978). Supervisor influence and subordinate mobility aspirations as moderators of consideration and initiating structure. Journal of Applied Psychology, 63, 96-102.

Ohbuchi, K., Hayashi, Y., \& Imazai, K. (2000). Motivational analysis of avoidance in organizational conflicts: Japanese business employees' concerns, strategies, and organizational attitudes. Psycholgia, 43, 211-220.

Oliver, N. (1984). An examination of organizational commitment in six workers' cooperatives in Scotland. Human Relations, 37, 29-46.

Oliver, N. (1990). Rewards, investments, alternatives and organizational commitment: Empirical evidence and theoretical development. Journal of Occupational Psychology, 63, 19-31.

Oliver, R. L., \& Anderson, E. (1994). An empirical test of the consequences of behavior- and outcome-based sales control systems. Journal of Marketing, 58, 53-67.

Oliver, R. L., \& Brief, A. P. (1977-1978). Determinants and consequences of role conflict and ambiguity among retail sales managers. Journal of Retailing, 53, 47-58.

Orpen, C. (1979). The effects of job enrichment on employee satisfaction, motivation, involvement, and performance: A field experiment. Human Relations, 32, 189-217.

Orpen, C. (1982). Correlated of academic job involvement: An empirical investigation. Psychological Research Journal, 6, 1-6. 
Orpen, C. (1986). Work values as a moderator of the effect of participation in budget-setting on employee satisfaction and performance. Psychological Studies, 31, 4247.

Orpen, C. (1995). The effect of organizational commitment on the relationship between communication quality and managerial attitudes. Psychological Studies, 40, 6064.

Orpen, C., \& Bonnici, J. (1990). The causes and consequences of pay satisfaction: A test of Lawler's model. Psychology, 27, 27-29.

Ostroff, C. (1993). The effects of climate and personal influences on individual behavior and attitudes in organizations. Organizational Behavior and Human Decision Processes, 56, 56-90.

Oswald, S. L., Mossholder, K. W., \& Harris, S. G. (1994). Vision salience and strategic involvement: Implications for psychological attachment to organization and job. Strategic Management Journal, 15, 477-489.

Parasuraman, S. (1982). Predicting turnover intentions and turnover behavior: A multivariate analysis. Journal of Vocational Behavior, 21, 111-121.

Parasuraman, S., \& Alutto, J. A. (1984). Sources and outcomes of stress in organizational settings: Toward the development of a structural model. Academy of Management Journal, 27, 330-350.

Parasuraman, S., \& Hansen, D. (1987). Coping with work stressors in nursing: Effects of adaptive versus maladaptive strategies. Work and Occupations, 14, 88-105.

Parasuraman, S., \& Nachman, S. A. (1987). Correlates of organizational and professional commitment: The case of musicians in symphony orchestras. Group and Organization Studies, 12, 287-303.

Parasuraman, S., \& Purohit, Y. S. (2000). Distress and boredom among orchestra musicians: The two faces of stress. Journal of Occupational Health Psychology, $\underline{5}, 74-83$.

Parasuraman, S., Purohit, Y. S., Godshalk, V. M., \& Beutell, N. J. (1996). Work and family variables, entrepreneurial career success, and psychological well-being. Journal of Vocational Behavior, 48, 275-300.

Parker, S. K. (2000). From passive to proactive motivation: The importance of flexible role orientations and role breadth self-efficacy. Applied Psychology: An International Review, 49, 447-469. 
Parnell, J. A., \& Hatem, T. (1999). Cultural antecedents of behavioural differences between American and Egyptian managers. Journal of Management Studies, 36, 399-418.

Patel, M. K. (1995). Job satisfaction and job involvement among nurses. Journal of the Indian Academy of Applied Psychology, 21, 119-125.

Paterson, J. M., \& O'Driscoll, M. P. (1989). Utility of the Australian Work Ethic Scale: Reliability and validity comparisons. Australian Journal of Psychology, 41, 285290.

Paterson, J. M., \& O'Driscoll, M. P. (1990). An empirical assessment of Kanungo's (1982) concept and measure of job involvement. Applied Psychology: An International Review, 39, 293-306.

Pathak, R. D. (1982). A study of job involvement and job performance among bank employees. Asian Journal of Psychology and Education. 7, 28-35.

Paullay, I. M., Alliger, G. M., \& Stone-Romero, E. F. (1994). Construct validation of two instruments designed to measure job involvement and work centrality. Journal of Applied Psychology, 79, 224-228.

Pazy, A., \& Zin, R. (1987). A contingency approach to consistency: A challenge to prevalent views. Journal of Vocational Behavior, 30, 84-101.

Pelled, L. H., \& Xin, K. R. (1997). Birds of a feather: Leader-member demographic similarity and organizational attachment in Mexico. Leadership Quarterly, 8, 433-450.

Pestonjee, D. M., Singh, A. P., \& Singh, S. P. (1981). Attitude towards union as related to morale and job involvement. International Review of Applied Psychology, 30, 209-216.

Peterson, M. F., Phillips, R. L., \& Duran, C. A. (1989). A comparison of Japanese performance-maintenance measures with U. S. leadership scales. Psychologia, 32, 58-70.

Pierce, C. A. (1998). Factors associated with participating in a romantic relationship in a work environment. Journal of Applied Social Psychology, 28, 17121730.

Pierce, J. L., \& Dunham, R. B. (1987). Organizational commitment: Preemployment propensity and initial work experiences. Journal of Management, 13, 163178. 
Pierce, J. L., Dunham, R. B., \& Blackburn, R. S. (1979). Social systems structure, job design, and growth need strength: A test of a congruency model. Academy of Management Journal, 22, 223-240.

Pillai, R., Schriesheim, C. A., \& Williams, E. S. (1999). Fairness perceptions and trust as mediators for transformational and transactional leadership: A two-sample study. Journal of Management, 25, 897-933.

Podsakoff, P. M., MacKenzie, S. B., \& Bommer, W. H. (1996). Transformational leader behaviors and substitutes for leadership as determinants of employee satisfaction, commitment, trust, and organizational citizenship behaviors. Journal of Management, 22 , 259-298.

Podsakoff, P. M., Niehoff, B. P., MacKenzie, S. B., \& Williams, M. L. (1993). Do substitutes for leadership really substitute for leadership? An empirical examination of Kerr and Jermier's situational leadership model. Organizational Behavior and Human Decision Processes, 54, 1-44.

Pond, S. B., III., Nacoste, R. W., Mohr, M. F., \& Rodriguez, C. M. (1997). The measurement of organizational citizenship behavior: Are we assuming too much? Journal of Applied Social Psychology, 27, 1527-1544.

Porat, A. B. (1979). The relationship between job involvement, job satisfaction and organizational factors. Psychology, 16, 25-32.

Porter, L. W., Steers, R. M., Mowday, R. T., \& Boulian, P. V. (1974). Organizational commitment, job satisfaction, and turnover among psychiatric technicians. Journal of Applied Psychology, 59, 603-609.

Prakash, A., \& Misra, S. (1986). Organizational outcome factors in relation to personal values of employees in banking organization. Indian Journal of Current Psychological Research, 1, 112-120.

Probst, T. M. (2000). Wedded to the job: Moderating effects of job involvement on the consequences of job insecurity. Journal of Occupational Health Psychology, 5, 6373.

Putti, J. M., Aryee, S., \& Liang, T. K. (1989). Work values and organizational commitment: A study in the Asian context. Human Relations, 42, 275-288.

Rabinowitz, S. (1981). Towards a developmental model of job involvement. International Review of Applied Psychology, 30, 31-50. 
Rabinowitz, S., Hall, D. T., \& Goodale, J. G. (1977). Job scope and individual differences as predictors of job involvement: Independent or interactive? Academy of Management Journal, 20, 273-281.

Raedeke, T. D., Granzyk, T. L., \& Warren, A. (2000). Why coaches experience burnout: A commitment perspective. Journal of Sport and Exercise Psychology, 22, 85105.

Rafaeli, A. (1986). Employee attitudes toward working with computers. Journal of Occupational Behaviour, 7, 89-106.

Rahim, M. A., \& Afza, M. (1993). Leader power, commitment, satisfaction, compliance, and propensity to leave a job among U.S. accountants. Journal of Social Psychology, 133, 611-625.

Rainey, H. G. (1983). Public agencies and private firms: Incentive structures, goals, and individual roles. Administration and Society, 15, 207-242.

Randall, D. M., \& Cote, J. A. (1991). Interrelationships of work commitment constructs. Work and Occupations, 18, 194-211.

Randall, D. M., Fedor, D. B., \& Longenecker, C.O. (1990). The behavioral expression of organizational commitment. Journal of Vocational Behavior, 36, 210-224.

Randall, D. M., \& O'Driscoll, M. P. (1997). Affective versus calculative commitment: Human resource implications. Journal of Social Psychology, 137, 606-617.

Randall, M. L., Cropanzano, R., Bormann, C. A., \& Birjulin, A. (1999). Organizational politics and organizational support as predictors of work attitudes, job performance, and organizational citizenship behavior. Journal of Organizational Behavior, 20, 159-174.

Reichers, A. E. (1986). Conflict and organizational commitments. Journal of Applied Psychology, 71, 508-514.

Reiley, J., \& Singer, M. (1996). Perceived fairness of promotion procedures: Identification of justice rules and consequences for job attitudes. International Journal of Selection and Assessment, 4, 129-138.

Reilly, N. P., \& Orsak, C. L. (1991). A career stage analysis of career and organizational commitment in nursing. Journal of Vocational Behavior, 39, 311-330. 
Reyes, P. (1989). The relationship of autonomy in decision making to commitment to schools and job satisfaction: A comparison between public school teachers and mid-level administrators. Journal of Research and Development in Education, 22, 6269.

Reyes, P. (1990). Individual work orientation and teacher outcomes. Journal of Educational Research, 83, 327-335.

Richardson, A. M., Burke, R. J., \& Leiter, M. P. (1992). Occupational demands, psychological burnout and anxiety among hospital personnel in Norway. Anxiety, Stress, and Coping, 5, 55-68.

Riggs, M. L., \& Knight, P. A. (1994). The impact of perceived group successfailure on motivational beliefs and attitudes: A causal model. Journal of Applied Psychology, 79, 755-766.

Riipinen, M. (1996). The relation of work involvement to occupational needs, need satisfaction, locus of control, and affect. Journal of Social Psychology, 136, 291303.

Riipinen, M. (1997). The relationship between job involvement and well-being. Journal of Psychology, 131, 81-89.

Riordan, C. M., \& Griffeth, R. W. (1995). The opportunity for friendship in the workplace: An underexplored construct. Journal of Business and Psychology, 10, 141154.

Riordan, C. M., \& Vandenberg, R. J. (1994). A central question in cross-cultural research: Do employees of different cultures interpret work-related measures in an equivalent manner? Journal of Management, 20, 643-671.

Ritzer, G., \& Trice, H. M. (1969). An empirical study of Howard Becker's sidebet theory. Social Forces, 47, 475-479.

Robbins, T. L., Summers, T. P., \& Miller, J. L. (2000). Intra- and inter-justice relationships: Assessing the direction. Human Relations, 53, 1329-1355.

Robert, C., Probst, T. M., Martocchio, J. J., Drasgow, F., \& Lawler, J. J. (2000). Empowerment and continuous improvement in the United States, Mexico, Poland, and India: Predicting fit on the basis of the dimensions of power distance and individualism. Journal of Applied Psychology, 85, 643-658. 
Robertson, I. T., lles, P. A., Gratton, L., \& Sharpley, D. (1991). The impact of personnel selection and assessment methods on candidates. Human Relations, 44, 963982.

Robinson, D., Porporino, F. J., \& Simourd, L. (1997). The influence of educational attainment on the attitudes and job performance of correctional officers. Crime and Delinquency, 43, 60-77.

Robinson, S. E., \& Skarie, E. K. (1986). Professional women: Job role stresses and psychosocial variables. American Mental Health Counselors Association Journal, 8, 157-165.

Robinson, S. L. (1995). Violation of psychological contracts: Impact on employee attitudes. In L.E. Tetrick \& J. Barling (Eds.), Changing employment relations: Behavioral and social perspectives (pp. 91-108). Washington, DC: APA.

Rodwell, J. J., Kienzle, R., \& Shadur, M. A. (1998). The relationships among work-related perceptions, employee attitudes, and employee performance: The integral role of communication. Human Resource Management, 37, 277-293.

Roe, R. A., Zinovieva, I. L., Dienes, E., \& Ten Horn, L.A. (2000). A comparison of work motivation in Bulgaria, Hungary, and the Netherlands: Test of a model. Applied Psychology: An International Review, 49, 658-687.

Rogelberg, S. G., Luong, A., Sederburg, M. E., \& Cristol, D. S. (2000). Employee attitude surveys: Examining the attitudes of noncompliant employees. Journal of Applied Psychology, 85, 284-293.

Romzek, B. S. (1989). Personal consequences of employee commitment. Academy of Management Journal, 32, 649-661.

Rosen, L. N., \& Martin, L. (1998). Incidence and perceptions of sexual harassment among male and female U.S. Army soldiers. Military Psychology, 10, 239257.

Rosin, H., \& Korabik, K. (1995). Organizational experiences and propensity to leave: A multivariate investigation of men and women managers. Journal of Vocational Behavior, 46, 1-16.

Rosin, H. M., \& Korabik, K. (1991). Workplace variables, affective responses, and intention to leave among women managers. Journal of Occupational Psychology, 64, 317-330. 
Rotondi, T., Jr. (1975). Organizational identification and group involvement. Academy of Management Journal, 18, 892-897.

Rotundo, D. (1999). Individual-difference variables and career-related coping. Journal of Social Psychology, 139, 458-471.

Rusbult, C. E., \& Farrell, D. (1983). A longitudinal test of the investment model: The impact on job satisfaction, job commitment, and turnover of variations in rewards, costs, alternatives, and investments. Journal of Applied Psychology, 68, 429-438.

Saal, F. E. (1978). Job involvement: A multivariate approach. Journal of Applied Psychology, 63, 53-61.

Saal, F. E. (1981). Empirical and theoretical implications of a purely cognitive definition of job involvement. International Review of Applied Psychology, 30, 103-120.

Sager, J. K. (1994). A structural model depicting salespeople's job stress. Journal of the Academy of Marketing Science, 22, 74-84.

Sagie, A. (1998). Employee absenteeism, organizational commitment, and job satisfaction: Another look. Journal of Vocational Behavior, 52, 156-171.

Sagie, A., \& Koslowsky, M. (1996). Decision type, organisational control, and acceptance of change: An integrative approach to participative decision making. Applied Psychology: An International Review, 45, 85-92.

Sagie, A., \& Weisberg, J. (1996). A structural analysis of behavior in work situations shared by group members. Journal of Psychology, 130, 371-381.

Saks, A. M. (1995). Longitudinal field investigation of the moderating and mediating effects of self-efficacy on the relationship between training and newcomer adjustment. Journal of Applied Psychology, 80, 211-225.

Saks, A. M., \& Ashforth, B. E. (1997). A longitudinal investigation of the relationships between job information sources, applicant perceptions of fit, and work outcomes. Personnel Psychology, 50, 395-426.

Saks, A. M., \& Ashforth, B. E. (2000). The role of dispositions, entry stressors, and behavioral plasticity theory in predicting newcomers' adjustment to work. Journal of Organizational Behavior, 21, 43-62.

Saks, A. M., Mudrack, P. E., \& Ashforth, B. E. (1996). The relationship between the work ethic, job attitudes, intentions to quit, and turnover for temporary service employees. Canadian Journal of Administrative Sciences, 13, 226-236. 
Sanchez, J. I., \& Brock, P. (1996). Outcomes of perceived discrimination among Hispanic employees: Is diversity management a luxury or a necessity? Academy of Management Journal, 39, 704-719.

Sass, J. S., \& Canary, D. J. (1991). Organizational commitment and identification: An examination of conceptual and operational convergence. Western Journal of Speech Communication, 55, 275-293.

Scandura, T. A. (1997). Mentoring and organizational justice: An empirical investigation. Journal of Vocational Behavior, 51, 58-69.

Scarpello, V., \& Jones, F. F. (1996). Why justice matters in compensation decision making. Journal of Organizational Behavior, 17, 285-299.

Scarpello, V., \& Vandenberg, R. J. (1992). Generalizing the importance of occupational and career views to job satisfaction attitudes. Journal of Organizational Behavior, 13, 125-140.

Schappe, S. P. (1996). Bridging the gap between procedural knowledge and positive employee attitudes: Procedural justice as keystone. Group and Organization Management, 21, 337-364.

Schappe, S. P. (1998). The influence of job satisfaction, organizational commitment, and fairness perceptions on organizational citizenship behavior. Journal of Psychology, 132, 277-290.

Schaubroeck, J. (1996). Pay status hierarchy and organizational attachment. Journal of Economic Psychology, 17, 579-589.

Schaubroeck, J., \& Fink, L. S. (1998). Facilitating and inhibiting effects of job control and social support on stress outcomes and role behavior: A contingency model. Journal of Organizational Behavior, 19, 167-195.

Schaubroeck, J., \& Jones, J. R. (2000). Antecedents of workplace emotional labor dimensions and moderators of their effects on physical symptoms. Journal of Organizational Behavior, 21, 163-183.

Schaubroeck, J., May, D. R., \& Brown, F. W. (1994). Procedural justice explanations and employee reactions to economic hardship: A field experiment. Journal of Applied Psychology, 79, 455-460.

Schell, B. H., \& Loeb, A. S. (1986). An investigation of general happiness level, collective bargaining attitudes, job satisfaction, and university and union commitment of faculty members in Canada. Journal of Social Behavior and Personality, 1, 537-556. 
Schmitt, N., White, J. K., Coyle, B. W., \& Rauschenberger, J. (1979). Retirement and life satisfaction. Academy of Management Journal, 22, 282-291.

Schriesheim, C. A., Castro, S. L., \& Yammarino, F. J. (2000). Investigating contingencies: An examination of the impact of span of supervision and upward controllingness on leader-member exchange using traditional and multivariate within- and between-entities analysis. Journal of Applied Psychology, 85, 659-677.

Schriesheim, C. A., Neider, L. L., Scandura, T. A., \& Tepper, B. J. (1992). Development and preliminary validation of a new scale (LMX-6) to measure leadermember exchange in organizations. Educational and Psychological Measurement, 52, 135-147.

Schuler, R. S. (1977). Moderating effects of job involvement and growth need strength on task-outcome relationships. Journal of Business Research, 5, 293-309.

Schweiger, D. M., \& Denisi, A. S. (1991). Communication with employees following a merger: A longitudinal field experiment. Academy of Management Journal, 34, 110-135.

Schwyhart, W. R., \& Smith, P. C. (1972). Factors in the job involvement of middle managers. Journal of Applied Psychology, 56, 227-233.

Seibert, S. (1999). The effectiveness of facilitated mentoring: A longitudinal quasiexperiment. Journal of Vocational Behavior, 54, 483-502.

Sekaran, U. (1982). An investigation of the career salience of men and women in dual-career families. Journal of Vocational Behavior, 20, 111-119.

Sekaran, U. (1989). Paths to the job satisfaction of bank employees. Journal of Organizational Behavior, 10, 347-359.

Shadur, M. A., Kienzle, R., \& Rodwell, J. J. (1999). The relationship between organizational climate and employee perceptions of involvement. Group and Organization Management, 24, 479-503.

Shaffer, M. A., \& Harrison, D. A. (1998). Expatriates' psychological withdrawal from international assignments: Work, nonwork, and family influences. Personnel Psychology, 51, 87-118.

Shaffer, M. A., Joplin, J. R. W., Bell, M. P., Lau, T., \& Oguz, C. (2000). Gender discrimination and job-related outcomes: A cross-cultural comparison of working women in the United States and China. Journal of Vocational Behavior, 57, 395-427. 
Shamir, B. (1985). Unemployment and 'free time': The role of Protestant work ethic and work involvement. Leisure Studies, 4, 333-345.

Shamir, B., \& Arthur, M. B. (1989). An exploratory study of perceived career change and job attitudes among job changers. Journal of Applied Social Psychology, 19, 701-716.

Sharma, S., \& Sharma, S. (1978). Interrelationship among measures of job involvement, job satisfaction and general anxiety. Asian Journal of Psychology and Education, 3, 35-39.

Shaw, J. B., Fields, M. W., Thacker, J. W., \& Fisher, C. D. (1993). The availability of personal and external coping resources: Their impact on job stress and employee attitudes during organizational restructuring. Work and Stress, 7, 229-246.

Shoemaker, D. J., Snizek, W. E., \& Bryant, C. D. (1977). Toward a further clarification of Becker's side-bet hypothesis as applied to organizational and occupational commitment. Social Forces, 56, 598-603.

Shore, L. M., \& Barksdale, K. (1998). Examining degree of balance and level of obligation in the employment relationship: A social exchange approach. Journal of Organizational Behavior, 19, 731-744.

Shore, L. M., Barksdale, K., \& Shore, T. H. (1995). Managerial perceptions of employee commitment to the organization. Academy of Management Journal, 38, 15931615 .

Shore, L. M., \& Martin, H. J. (1989). Job satisfaction and organizational commitment in relation to work performance and turnover intentions. Human Relations, 42, 625-638.

Shore, L. M., \& Newton, L. A. (1995). Union-member relations: Loyalty, instrumentality, and alienation. In L.E. Tetrick \& J. Barling (Eds.), Changing employment relations: Behavioral and social perspectives (pp. 189-208). Washington, DC: APA.

Shore, L. M., Newton, L. A., \& Thornton, G. C., III. (1990). Job and organizational attitudes in relation to employee behavioral intentions. Journal of Organizational Behavior, 11, 57-67.

Shore, L. M., \& Tetrick, L. E. (1991). A construct validity study of the Survey of Perceived Organizational Support. Journal of Applied Psychology, 76, 637-643. 
Shore, L. M., Tetrick, L. E., Shore, T. H., \& Barksdale, K. (2000). Construct validity of measures of Becker's side bet theory. Journal of Vocational Behavior, 57, 428444.

Shore, L. M., Tetrick, L. E., Sinclair, R. R., \& Newton, L. A. (1994). Validation of a measure of perceived union support. Journal of Applied Psychology, 79, 971-977.

Shore, L. M., \& Wayne, S. J. (1993). Commitment and employee behavior: Comparison of affective commitment and continuance commitment with perceived organizational support. Journal of Applied Psychology, 78, 774-780.

Shore, T. H., Thornton, G. C., III, \& Shore, L. M. (1990). Distinctiveness of three work attitudes: Job involvement, organizational commitment, and career salience. Psychological Reports, 67, 851-858.

Siders, M. A., George, G., \& Dharwadkar, R. (2001). The relationship of internal and external commitment foci to objective job performance measures. Academy of Management Journal, 44, 570-579.

Siegall, M., \& McDonald, T. (1995). Focus of attention and employee reactions to job change. Journal of Applied Social Psychology, 25, 1121-1141.

Siegel, A. L., \& Ruh, R. A. (1973). Job involvement, participation in decision making, personal background and job behavior. Organizational Behavior and Human Performance, 9, 318-327.

Siguaw, J. A., Brown, G., \& Widing, R. E., II. (1994). The influence of the market orientation of the firm on sales force behavior and attitudes. Journal of Marketing Research, 31, 106-116.

Siguaw, J. A., \& Honeycutt, E. D., Jr. (1995). An examination of gender differences in selling behaviors and job attitudes. Industrial Marketing Management, 24, 45-52.

Sims, R. L. (2000). The relationship between employee attitudes and conflicting expectations for lying behavior. Journal of Psychology, 134, 619-633.

Sims, R. L., \& Kroeck, K. G. (1994). The influence of ethical fit on employee satisfaction, commitment and turnover. Journal of Business Ethics, 13, 939-947.

Sinclair, R. R., Hannigan, M. A., \& Tetrick, L. E. (1995). Benefit coverage and employee attitudes: A social exchange perspective. In L.E. Tetrick \& J. Barling (Eds.), Changing employment relations: Behavioral and social perspectives (pp. 163-185).

Washington, DC: APA. 
Sinclair, R. R., \& Tetrick, L. E. (1995). Social exchange and union commitment: A comparison of union instrumentality and union support perceptions. Journal of Organizational Behavior, 16, 669-680.

Singh, A. P., \& Mishra, P. C. (1984). Ego-strength as a moderator variable of the job involvement-job satisfaction relationship. Psychological Studies, 29, 9-12.

Singh, J. (1998). Striking a balance in boundary-spanning positions: An investigation of some unconventional influences of role stressors and job characteristics on job outcomes of salespeople. Journal of Marketing, 62, 69-86.

Singh, J., Goolsby, J. R., \& Rhoads, G. K. (1994). Behavioral and psychological consequences of boundary spanning burnout for customer service representatives. Journal of Marketing Research, 31, 558-569.

Singh, K., \& Billingsley, B. S. (1996). Intent to stay in teaching: Teachers of students with emotional disorders versus other special educators. Remedial and Special Education, 17, 37-47.

Singh, K., \& Billingsley, B. S. (1998). Professional support and its effects on teachers' commitment. Journal of Educational Research, 91, 229-239.

Singh, R. P., \& Pandey, J. (1988). Losing a base of power through routinized rewards. Vikalpa, 13, 63-67.

Sinha, P. (1986). Factors for job satisfaction: For a quality of work. Indian Journal of Behaviour, 10, 24-36.

Siu, O. L., \& Cooper, C. L. (1998). A study of occupational stress, job satisfaction and quitting intention in Hong Kong Firms: The role of locus of control and organizational commitment. Stress Medicine, 14, 55-66.

Sjoberg, A. (1997). Predicting turnover among nurses: The role of job involvement and organizational commitment. Reports from the Department of Psychology, Stockholm University, No. 827.

Sjoberg, A., \& Sverke, M. (2000). The interactive effect of job involvement and organizational commitment on job turnover revisited: A note on the mediating role of turnover intention. Scandinavian Journal of Psychology, 41, 247-252.

Slocombe, T. E., \& Bluedorn, A. C. (1999). Organizational behavior implications of the congruence between preferred polychronicity and experienced work-unit polychronicity. Journal of Organizational Behavior, 20, 75-99. 
Slocombe, T. E., \& Dougherty, T. W. (1998). Dissecting organizational commitment and its relationship with employee behavior. Journal of Business and Psychology, 12, 469-491.

Smart, R. M. (1998). Career stages in Australian professional women: A test of Super's model. Journal of Vocational Behavior, 52, 379-395.

Smart, R., \& Peterson, C. (1994). Stability versus transition in women's career development: A test of Levinson's theory. Journal of Vocational Behavior, 45, 241-260.

Smith, C. S., \& Brannick, M. T. (1990). A role and expectancy model of participative decision-making: A replication and theoretical extension. Journal of Organizational Behavior, 11, 91-104.

Smith, C. S., \& Tisak, J. (1993). Discrepancy measures of role stress revisited: New perspectives on old issues. Organizational Behavior and Human Decision Processes, 56, 285-307.

Smith, T. S., \& Murphy, R. J. (1984). Conflicting criteria of success in the careers of symphony musicians. Empirical Studies of the Arts, 2, 149-172.

Snyder, R. A., Verderber, K. S., \& Morris, J. H. (1986). Voluntary union membership of women and men: Differences in personal characteristics, perceptions and attitudes. Journal of Occupational Psychology, 59, 205-216.

Somers, M. J. (1995). Organizational commitment, turnover and absenteeism: An examination of direct and interaction effects. Journal of Organizational Behavior, 16, 4958.

Somers, M. J. (1999). Application of two neural network paradigms to the study of voluntary employee turnover. Journal of Applied Psychology, 84, 177-185.

Somers, M. J., \& Birnbaum, D. (1998). Work-related commitment and job performance: It's also the nature of the performance that counts. Journal of Organizational Behavior, 19, 621-634.

Somers, M. J., \& Birnbaum, D. (1999). Survival versus traditional methodologies for studying employee turnover: Differences, divergences and directions for future research. Journal of Organizational Behavior, 20, 273-284.

Spence, J. T., \& Robins, A. S. (1992). Workaholism: Definition, measurement, and preliminary results. Journal of Personality Assessment, 58, 160-178. 
Starnaman, S. M., \& Miller, K. I. (1992). A test of a causal model of communication and burnout in the teaching profession. Communication Education, 41, 40-53.

Stedham, Y., \& Mitchell, M. C. (1996). Voluntary turnover among nonsupervisory casino employees. Journal of Gambling Studies, 12, 269-290.

Steel, R. P., Jennings, K. R., Mento, A. J., \& Hendrix, W. H. (1992). Effects of perceived decision-making influence on labor relations and organizational outcomes. Group and Organization Management, 17, 24-43.

Steel, R. P., Mento, A. J., Dilla, B. L., \& Ovale, N. K., II. (1985). Factors influencing the success and failure of two quality circle programs. Journal of Management, 11, 99-119.

Steers, R. M. (1975). Effects of need for achievement on the job performance-job attitude relationship. Journal of Applied Psychology, 60, 678-682.

Steers, R. M. (1977). Antecedents and outcomes of organizational commitment. Administrative Science Quarterly, 22, 46-56.

Steffy, B. D., \& Jones, J. W. (1988). The impact of family and career planning variables on the organizational, career, and community commitment of professional women. Journal of Vocational Behavior, 32, 196-212.

Stevens, J. M., Beyer, J. M., \& Trice, H. M. (1978). Assessing personal, role, and organizational predictors of managerial commitment. Academy of Management Journal, 21, 380-396.

Stewart-Belle, S., \& Lust, J. A. (1999). Career movement of female employees holding lower-level positions: An analysis of the impact of the Type A behavior pattern. Journal of Business and Psychology, 14, 187-197.

Stone, E. F., \& Porter, L. W. (1975). Job characteristics and job attitudes: A multivariate study. Journal of Applied Psychology, 60, 57-64.

Strasser, S., Dailey, R. C., \& Bateman, T. S. (1981). Attitudinal moderators and effects of leaders' punitive behavior. Psychological Reports, 49, 695-698.

Stremmel, A. J. (1991). Predictors of intention to leave child care work. Early Childhood Research Quarterly, 6, 285-298. 
Strumpfer, D. J. W. (1997). The relation between religious motivation and workrelated variables amongst agricultural workers. South African Journal of Psychology, 27, 134-142.

Stumpf, S. A. (1981). Career roles, psychological success, and job attitudes. Journal of Vocational Behavior, 19, 98-112.

Stumpf, S. A., \& Hartman, K. (1984). Individual exploration to organizational commitment or withdrawal. Academy of Management Journal, 27, 308-329.

Summers, T. P., DeNisi, A. S., \& DeCotiis, T. A. (1989). Attitudinal and behavioral consequences of felt job stress and its antecedent factors: A field study using a new measure of felt stress. Journal of Social Behavior and Personality, 4, 503-520.

Sverke, M., \& Hellgren, J. (2001). Exit, voice and loyalty reactions to job insecurity in Sweden: Do unionized and non-unionized employees differ? British Journal of Industrial Relations, 39, 167-182.

Sverke, M., \& Kuruvilla, S. (1995). A new conceptualization of union commitment: Development and test of an integrated theory. Journal of Organizational Behavior, 16, 505-532.

Sverke, M., \& Sjoberg, A. (1994). Dual commitment to company and union in Sweden: An examination of predictors and taxonomic split methods. Economic and Industrial Democracy, 15, 531-564.

Sverke, M., \& Sjoberg, A. (1995). Union membership behavior: The influence of instrumental and value-based commitment. In L.E. Tetrick \& J. Barling (Eds.), Changing employment relations: Behavioral and social perspectives (pp. 229-251). Washington, DC: APA.

Sweeney, P. D., \& McFarlin, D. B. (1993). Workers' evaluations of the "ends" and the "means": An examination of four models of distributive and procedural justice. Organizational Behavior and Human Decision Processes, 55, 23-40.

Tan, D. S. K., \& Akhtar, S. (1998). Organizational commitment and experienced burnout: An exploratory study from a Chinese cultural perspective. The International Journal of Organizational Analysis, 6, 310-333.

Tang, T. L., Baldwin, L. J., \& Frost, A. G. (1997). Locus of control as a moderator of the self-reported performance feedback-personal sacrifice relationship. Personality and Individual Differences, 22, 201-211. 
Tang, T. L., Kim, J. K., \& Tang, D. S. (2000). Does attitude toward money moderate the relationship between intrinsic job satisfaction and voluntary turnover? Human Relations, 53, 213-245.

Tansky, J. W. (1993). Justice and organizational citizenship behavior: What is the relationship? Employee Responsibilities and Rights Journal, 6, 195-207.

Tansky, J. W., Gallagher, D. G., \& Wetzel, K. W. (1997). The effect of demographics, work status, and relative equity on organizational commitment: Looking among part-time workers. Canadian Journal of Administrative Sciences, 14, 315-326.

Taylor, M. A., \& Shore, L. M. (1995). Predictors of planned retirement age: An application of Beehr's model. Psychology and Aging, 10, 76-83.

Taylor, M. S., Audia, G., \& Gupta, A. K. (1996). The effect of lengthening job tenure on managers' organizational commitment and turnover. Organization Science, 7 , 632-648.

Taylor, P. J., \& Pierce, J. L. (1999). Effects of introducing a performance management system on employees' subsequent attitudes and effort. Public Personnel Management, 28, 423-452.

Tenbrunsel, A. E., Brett, J. M., Moaz, E., Stroh, L. K., \& Reilly, A. H. (1995). Dynamic and static work-family relationships. Organizational Behavior and Human Decision Processes, 63, 233-246.

Tepper, B. J. (2000). Consequences of abusive supervision. Academy of Management Journal, 43, 178-190.

Tesluk, P. E., Vance, R. J., \& Mathieu, J. E. (1999). Examining employee involvement in the context of participative work environments. Group and Organization Management, 24, 271-299.

Testa, M. R. (2001). Organizational commitment, job satisfaction, and effort in the service environment. Journal of Psychology, 135, 226-236.

Tetrick, L. E., Thacker, J. W., \& Fields, M. W. (1989). Evidence for the stability of the four dimensions of the Commitment to the Union Scale. Journal of Applied Psychology, 74, 819-822.

Thacker, J.W., Fields, M. W., \& Barclay, L. A. (1990). Union commitment: An examination of antecedent and outcome factors. Journal of Occupational Psychology, 63, $33-48$. 
Thacker, J. W., Fields, M. W., \& Tetrick, L. E. (1989). The factor structure of union commitment: An application of confirmatory factor analysis. Journal of Applied Psychology, 74, 228-232.

Thompson, C. A., Beauvais, L. L., \& Lyness, K. S. (1999). When work-family benefits are not enough: The influence of work-family culture on benefit utilization, organizational attachment, and work-family conflict. Journal of Vocational Behavior, 54, $392-415$.

Thompson, C. A., \& Blau, G. (1993). Moving beyond traditional predictors of job involvement: Exploring the impact of work-family conflict and overload. Journal of Social Behavior and Personality, 8, 635-646.

Ting, Y. (1996). Analysis of job satisfaction of the federal white-collar work force: Findings from the Survey of Federal Employees. American Review of Public Administration, 26, 439-456.

Tompson, H. B., \& Werner, J. M. (1997). The impact of role conflict/facilitation on core and discretionary behaviors: Testing a mediated model. Journal of Management, 23, 583-601.

Tsui, A. S., Egan, T. D., \& O'Reilly, C. A., III. (1992). Being different: Relational demography and organizational attachment. Administrative Science Quarterly, 37, 549579.

Tuma, N. B., \& Grimes, A. J. (1981). A comparison of models of role orientations of professionals in a research-oriented university. Administrative Science Quarterly, 26, 187-206.

Turban, D. B., Campion, J. E., \& Eyring, A. R. (1992). Factors relating to relocation decisions of research and development employees. Journal of Vocational Behavior, 41, 183-199.

Tyagi, P. K., Wotruba, T. R. (1993). An exploratory study of reverse causality relationships among sales force turnover variables. Journal of the Academy of Marketing Science, 21, 143-153.

Tziner, A., \& Murphy, K. R. (1999). Additional evidence of attitudinal influences in performance appraisal. Journal of Business and Psychology, 13, 407-419.

Udo, G. J., Guimaraes, T., \& Igbaria, M. (1997). An investigation of the antecedents of turnover intention for manufacturing plant managers. International Journal of Operations and Production Management, 17, 912-930. 
van Breda, A. D. (2000). The practical value of strategic direction. Administration in Social Work, 24, 1-16.

Van Der Vegt, G., Emans, B., \& Van De Vliert, E. (2000). Team members' affective responses to patterns of intragroup interdependence and job complexity. Journal of Management, 26, 633-655.

Van Knippenberg, D., \& van Schie, E. C. M. (2000). Foci and correlates of organizational identification. Journal of Occupational and Organizational Psychology, 73 , 137-147.

Van Maanen, J. (1975). Police socialization: A longitudinal examination of job attitudes in an urban police department. Administrative Science Quarterly, 20, 207-228.

Van Scotter, J. R., \& Motowidlo, S. J. (1996). Interpersonal facilitation and job dedication as separate facts of contextual performance. Journal of Applied Psychology, 81, 525-531.

Van Vianen, A. E. M. (2000). Person-organization fit: The match between newcomers' and recruiters' preferences for organizational cultures. Personnel Psychology, 53, 113-149.

Van Yperen, N. W., Hagedoorn, M., \& Geurts, S. A. E. (1996). Intent to leave and absenteeism as reactions to perceived inequity: The role of psychological and social constraints. Journal of Occupational and Organizational Psychology, 69, 367-372.

Vancouver, J. B., \& Schmitt, N. W. (1991). An exploratory examination of person-organization fit: Organizational goal congruence. Personnel Psychology, 44, 333352.

Vandenberg, R. J., \& Lance, C. E. (1992). Examining the causal order of job satisfaction and organizational commitment. Journal of Management, 18, 153-167.

Vandenberg, R. J., \& Nelson, J. B. (1999). Disaggregating the motives underlying turnover intentions: When do intentions predict turnover behavior? Human Relations, 52 , 1313-1336.

Vandenberg, R. J., Richardson, H. A., \& Eastman, L. J. (1999). The impact of high involvement work processes on organizational effectiveness: A second-order latent variable approach. Group and Organization Management, 24, 300-339.

Vandenberg, R. J., \& Scarpello, V. (1994). A longitudinal assessment of the determinant relationship between employee commitments to the occupation and the organization. Journal of Organizational Behavior, 15, 535-547. 
Vandenberg, R. J., Self, R. M., \& Seo, J. H. (1994). A critical examination of the internalization, identification, and compliance commitment measures. Journal of Management, 20, 123-140.

Vandenberghe, C., Stinglhamber, F., Bentein, K., \& Delhaise, T. (2001). An examination of the cross-cultural validity of a multidimensional model of commitment in Europe. Journal of Cross-Cultural Psychology, 32, 322-347.

Vardi, Y., \& Riva, S. (1994). Careers of registered nurses in a general hospital: Mobility vs. non-mobility. Man and Work, 5, 63-82.

Vashishtha, A., \& Mishra, P. C. (1999). Social support as related to organizational commitment of supervisors. Journal of the Indian Academy of Applied Psychology, 25, 71-74.

Vecchio, R. P. (1995). The impact of referral sources on employee attitudes: Evidence from a national sample. Journal of Management, 21, 953-965.

Verma, O. P., \& Upadhyay, S. N. (1986). Organizational commitment, job involvement and job satisfaction. Indian Journal of Current Psychological Research, 1, 24-31.

Vigoda, E. (2000). Organizational politics, job attitudes, and work outcomes: Exploration and implications for the public sector. Journal of Vocational Behavior, 57 , 326-347.

Viswesvaran, C., \& Deshpande, S. P. (1993). Are conclusions of union commitment robust to empirical techniques employed? Relations Industrielles, 48, 539558.

Viviers, A. M. (1999). A cross-cultural investigation into three measures of work orientation. In W. J. Lonner, D. L. Dinnel, D. K. Forgays, \& S.A. Hayes (Eds.), Merging past, present, and future in cross-cultural psychology (pp.503-509). Lisse, The Netherlands: Swets and Zeiltinger Publishers.

Wagner, S. L., \& Rush, M. C. (2000). Altruistic organizational citizenship behavior: Context, disposition, and age. Journal of Social Psychology, 140, 379-391.

Waldersee, R., \& Luthans, F. (1994). The impact of positive and corrective feedback on customer service performance. Journal of Organizational Behavior, 15, 8395. 
Wall, T. B., Kemp, N. J., Jackson, P. R., \& Clegg, C. W. (1986). Outcomes of autonomous workgroups: A long-term field experiment. Academy of Management Journal, 29, 280-304.

Wallace, J. E. (1997). It's about time: A study of hours worked and work spillover among law firm lawyers. Journal of Vocational Behavior, 50, 227-248.

Wanberg, C. R., Kanfer, R., \& Rotundo, M. (1999). Unemployed individuals: Motives, job-search competencies, and job-search constraints as predictors of job seeking and reemployment. Journal of Applied Psychology, 84, 897-910.

Warr, P., Cook, J., \& Wall, T. (1979). Scales for the measurement of some work attitudes and aspects of psychological well-being. Journal of Occupational Psychology, $\underline{52}, 129-148$.

Weaver, C. N. (1997). Examining a work ethic myth about self-employed people. Psychological Reports, 81, 1075-1081.

Webb, N. C., \& Lowther, M. A. (1993). Organizational commitment of child care providers employed in center facilities. Journal of Child and Youth Care, 8, 1-16.

Wech, B. A., Mossholder, K. W., Steel, R. P., \& Bennett, N. (1998). Does work group cohesiveness affect individuals' performance and organizational commitment: A cross-level examination. Small Group Research, 29, 472-494.

Weissenberg, P., \& Gruenfeld, L. W. (1968). Relationship between job satisfaction and job involvement. Journal of Applied Psychology, 52, 469-473.

Welsch, H. P., \& La Van, H. (1981). Inter-relationships between organizational commitment and job characteristics, job satisfaction, professional behavior, and organizational climate. Human Relations, 34, 1079-1089.

Werbel, J. D., \& Gould, S. (1984). A comparison of the relationship of commitment to turnover in recent hires and tenured employees. Journal of Applied Psychology, 69, 687-690.

Whitener, E. M., \& Walz, P. M. (1993). Exchange theory determinants of affective and continuance commitment and turnover. Journal of Vocational Behavior, 42, 265-281.

Wiener, Y., Muczyk, J. P., \& Gable, M. (1987). Relationships between work commitments and experience of personal well-being. Psychological Reports, 60, 459-466. 
Wiener, Y., Muczyk, J. P., \& Martin, H. J. (1992). Self-esteem and job involvement as moderators of the relationship between work satisfaction and well-being. Journal of Social Behavior and Personality. 7 , 539-554.

Wiener, Y., \& Vardi, Y. (1980). Relationships between job, organization, and career commitments and work outcomes: An integrative approach. Organizational Behavior and Human Performance, 26, 81-96.

Wiener, Y., Vardi, Y., \& Muczyk, J. (1981). Antecedents of employees' mental health: The role of career and work satisfaction. Journal of Vocational Behavior, 19, 5060 .

Wiley, D. L. (1987). The relationship between work/nonwork role conflict and job-related outcomes: Some unanticipated findings. Journal of Management, 13, 467-472.

Williams, L. J., \& Anderson, S. E. (1991). Job satisfaction and organizational commitment as predictors of organizational citizenship and in-role behaviors. Journal of Management, 17, 601-617.

Williams, L. J., Gavin, M. B., \& Williams, M. L. (1996). Measurement and nonmeasurement processes with negative affectivity and employee attitudes. Journal of Applied Psychology, 81, 88-101.

Williams, M. L., Podsakoff, P. M., \& Huber, V. (1992). Effects of group-level variation in leader behaviours on subordinate attitudes and performance. Journal of Occupational and Organizational Psychology, 65, 115-129.

Williams, S. \& Cooper, C. L. (1998). Measuring occupational stress: Development of the Pressure Management Indicator. Journal of Occupational Health Psychology, 3, 306-321.

Witt, L. A. (1989). Sex differences among bank employees in the relationships of commitment with psychological climate and job satisfaction. Journal of General Psychology, 116, 419-426.

Witt, L. A. (1991). Exchange ideology as a moderator of job attitudes: Organizational citizenship behaviors relationships. Journal of Applied Social Psychology, 21, 1490-1501.

Witt, L. A. (1993). Reactions to work assignment as predictors of organizational commitment: The moderating effect of occupational identification. Journal of Business Research, 26, 17-30. 
Witt, L. A. (1998). Enhancing organizational goal congruence: A solution to organizational politics. Journal of Applied Psychology, 83, 666-674.

Witt, L.A., \& Beorkrem, M. N. (1991). Satisfaction with initial work assignment and organizational commitment. Journal of Applied Social Psychology, 21, 1783-1792.

Witt, L. A., \& Nye, L. G. (1992). Organizational goal congruence and job attitudes revisited. FAA Office of Aviation Medicine Reports, FAA-AM-92-8.

Wolfgang, A. P., \& Ortmeier, B. G. (1993). Career commitment, career plans, and job-related stress: A follow-up study of pharmacy students as pharmacists. American Journal of Pharmaceutical Education, 57, 25-28.

Wright, T. A. (1997). Job performance and organizational commitment. Perceptual and Motor Skills, 85, 447-450.

Wunder, R. S., Dougherty, T. W., \& Welsh. M. A. (1982). A causal model of role stress and employee turnover. Academy of Management Best Paper Proceedings, 297301.

Young, B. S., Worchel, S., \& Woehr, D. J. (1998). Organizational commitment among public service employees. Public Personnel Management, 27, 339-348.

Yousef, D. A. (2000). Organizational commitment and job satisfaction as predictors of attitudes towards organizational change in a non-western setting. Personnel Review, 29, 567-592.

Yousef, D. A. (2000). Organizational commitment as a mediator of the relationship between Islamic work ethic and attitudes toward organizational change. Human Relations, 53, 513-537.

Yousef, D. A. (2001). Islamic work ethic: A moderator between organizational commitment and job satisfaction in a cross-cultural context. Personnel Review, 30, 152169.

Zaccaro, S. J., \& Dobbins, G. H. (1989). Contrasting group and organizational commitment: Evidence for differences among multilevel attachments. Journal of Organizational Behavior, 10, 267-273.

Zalesny, M. D., \& Farace, R. V. (1988). Job function, sex, and environment as correlates of work perceptions and attitudes. Journal of Applied Social Psychology, 18, 179-202. 
April 29, 1977

1997

1999

1999-2001
Born, Bethesda, Maryland

B.A., Honors in Religious Studies Florida International University Miami, Florida

M.S., Psychology

Florida International University

Miami, Florida

Graduate Assistant

Florida International University

Miami, Florida

\section{PUBLICATIONS AND PRESENTATIONS}

Cooper, A. R., \& Viswesvaran, C. (In Press). A meta-analytic review of the MacAndrew Alcoholism Scale. Educational and Psychological Measurement.

Cooper, A. R., Viswesvaran, C., \& Sanchez, J. I. (2000). Employee health, role theory, and negative affectivity: Testing alternate models. Paper presented at the American Psychological Association Annual Meeting.

Cooper, A. R., Viswesvaran, C., \& Sanchez, J. I. (2000). Negative affect, role theory, and organizational commitment: Testing alternate 
models. Paper presented at the American Psychological Association Annual Meeting.

Cooper, A. R., Viswesvaran, C., \& Sanchez, J. I. (2000). Negative affectivity and its impact on role conflict, role ambiguity, and job satisfaction. Paper presented at the Society for Industrial and Organizational Psychologists Annual Meeting.

Cooper, A. R., \& Viswesvaran, C. (2000). The predictive validity of MacAndrew Alcoholism Scale is robust across studies. Paper presented at the American Psychological Society Annual Meeting. 